$$
\begin{aligned}
& \text { QL } \\
& 690 \\
& \text { A45 } \\
& \text { Birds }
\end{aligned}
$$


Smithsonian Institution Sibraries

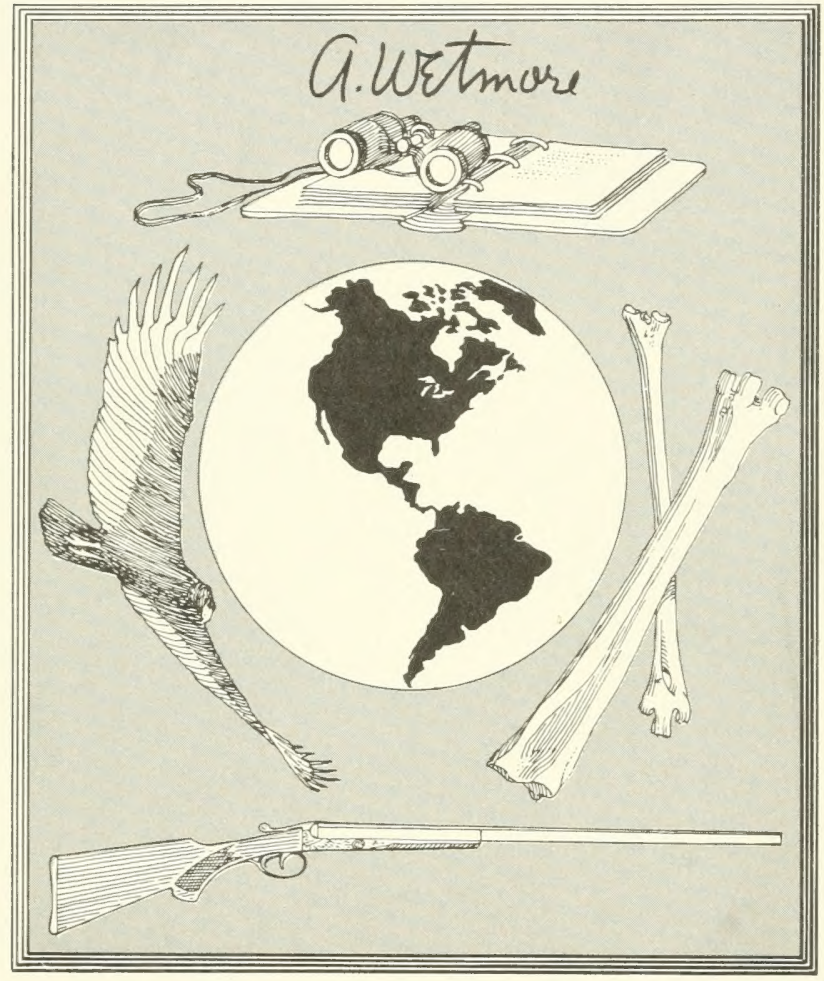

Alexander Wetmore

1946 Sixth Secretary 1953

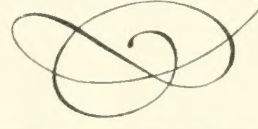




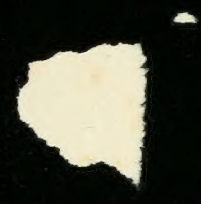




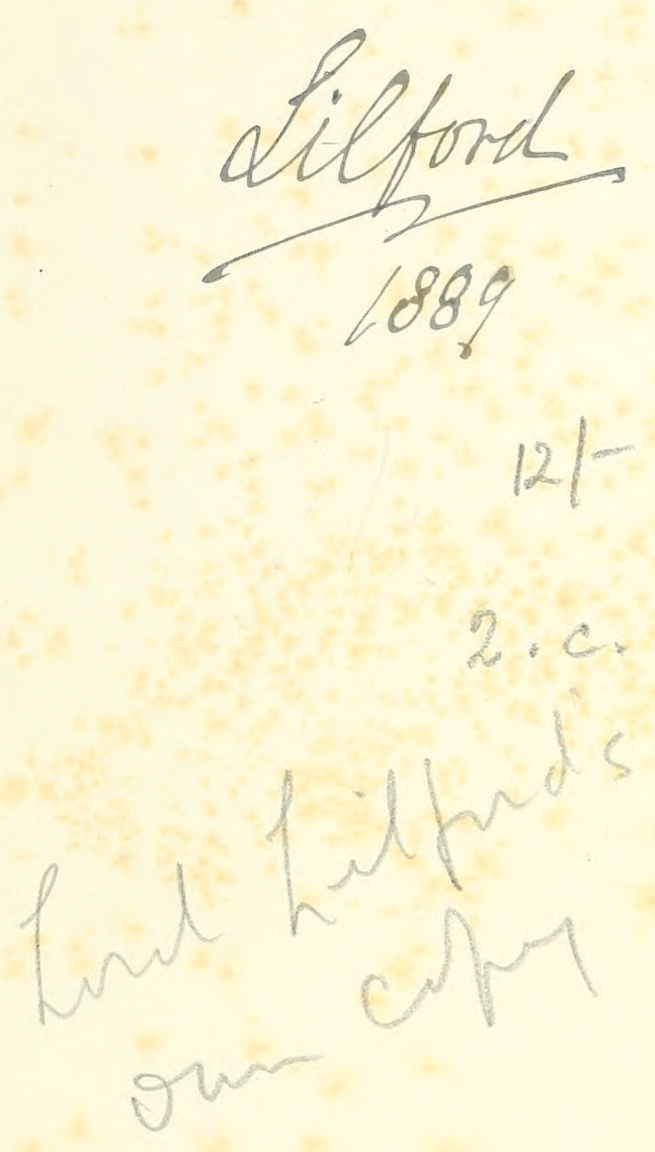


THE

\section{BIRDS OF OXFORDSHIRE}

APLIN 




HENRY FROWDE

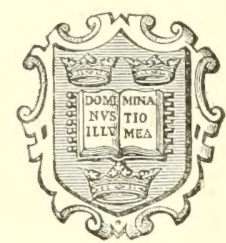

Oxford University Press Warehouse Amen Corner, E.C. 


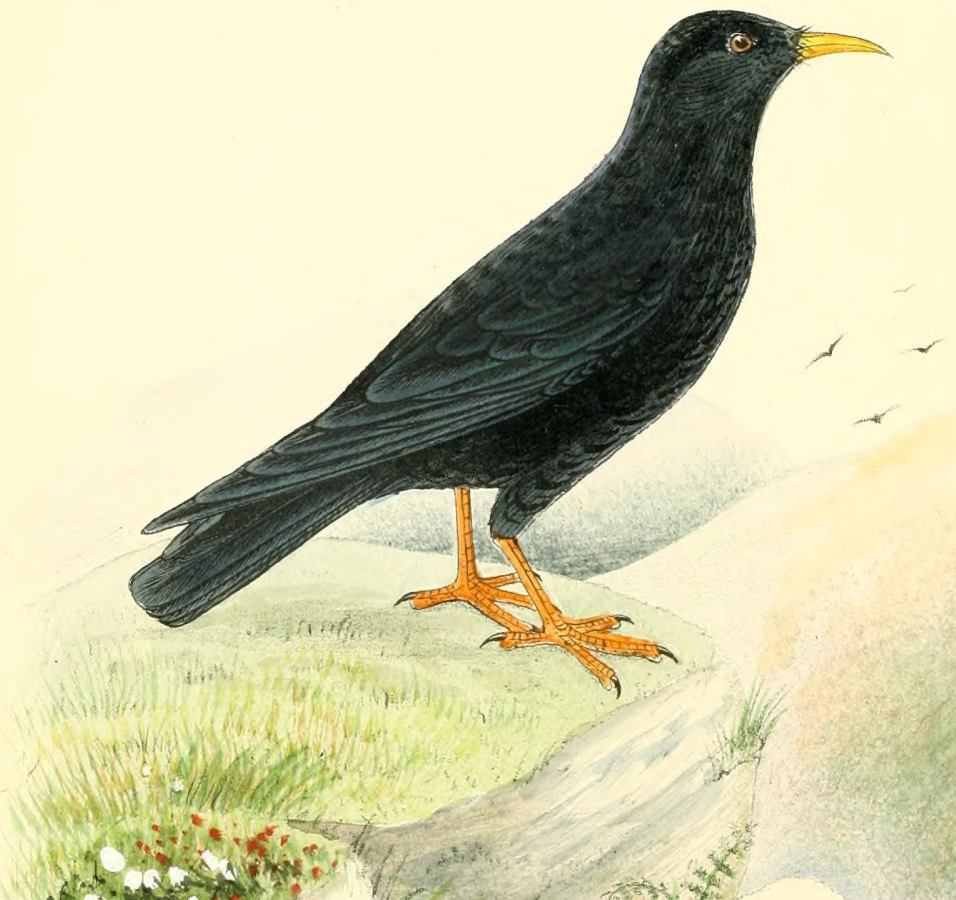

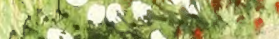
angace r.
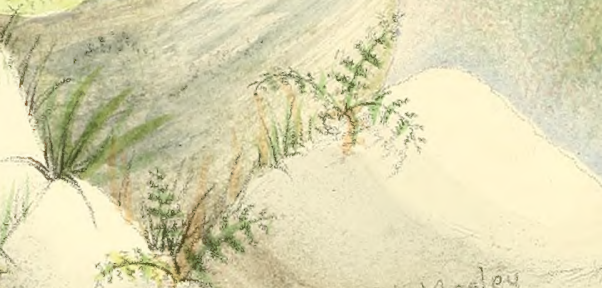

30.4)

$y=y_{2}=-5 x$ masteu

$a^{6}$

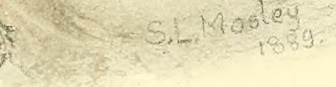

$$
\text { ALPINE CHOUGH. }
$$




\title{
THE
}

\section{BIRDS OF OXFORDSHIRE}

BY

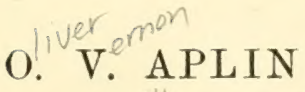

MEMBER OF THE BRITISH ORNITHOLOGISTS' UNION

\section{With a Map}

\begin{abstract}
'Here are no stories told you of what is to be seen at the other end of the world, but of things at home, in your own Native Country, at your own doors, easily examinable with little travel, less cost, and very little hazard.'

Childrey, I66I.
\end{abstract}

\section{Orford}

AT THE CLARENDON PRESS

1889

[ All rights reserved]

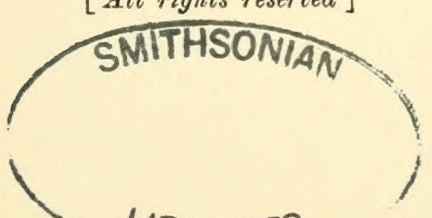

\section{LIBRARIES}


'While Quires of winged Songsters of the air, The woods and groves with tuneful numbers cheer.'

Camden.--'Wedding of Tame and Isis.' 


\section{PREF A CE.}

Within the last thirty years a number of works treating of the ornithology of different districts in Great Britain have appeared. Not only do these afford to the resident of some particular locality trustworthy information about the birds of his own neighbourhood, but they also supply ornithologists generally with the means of comparing the avifauna of various districts, and of determining with some accuracy the distribution of the birds of these islands during the time which they spend within our shores.

With the exception of Middlesex, Nottinghamshire, Northamptonshire, Herefordshire, Wiltshire, Berkshire, and Euckinghamshire, the counties thus treated of have been those possessing a considerable extent of seaboard, and no work upon the birds of Oxfordshire in a collected and accessible form has yet been written.

To fill up this blank, in some measure at the least, by contributing to the series of county faunal works the requisite information relating to Oxfordshire, and to furnish the residents in the county with some idea of the bi ds around them, are the objects of the present volume.

For some years past I have been engaged in collecting materials for an account of the Birds of Oxfordshire, and during that time, partly by personal observation, and partly 
through the assistance of friends and correspondents who have paid attention to the birds of the county at various times, a considerable amount of information relating to the subject has been amassed.

With the exception of occasional and casual observations made during visits to the other districts, my own personal investigations have been confined to the northern part of the county, where I have lived most of my life. In tracing therefore the history of our more common species, my remarks, unless the contrary is expressed, must be understood to apply more particularly to that district, although probably true of the whole of the county.

Correct as far as it goes it is believed that the present essay will be found to be, but complete I can hardly hope that it is. For it is highly probable that there are preserved in the county specimens of many of our more uncommon visitors, the existence of which there has been no opportunity of discovering, and of whose capture no record is now forthcoming, while a still larger number of rare birds have doubtless been procured at different times which were not preserved, and have been forgotten. A more exhaustive research into the zoological and antiquarian literature of this country than I have been able to make, might also reveal records bearing upon the subject; while from certain ontlying corners of the county I have failed to obtain from resident observers as full information as I could wish.

Any notes or observations upon the ornithology of Oxfordshire will always be gratefully received, and earefully preserved; meanwhile it is hoped that in its present form this volume may, in some measure at least, fulfil the objects for which it was commenced, and that the material here collected may prove serviceable as a basis for a fuller account of the birds of this inland county, should another edition be called for. 
Further notes, supplementing those in the body of the work, upon the Marsh Warbler, Grey Wagtail, Cirl Bunting, Tree Sparrow, House Sparrow, Hawfinch, Lesser Redpole, Crossbill, Cuckoo, Wryneck, Turtle Dove, Woodcock, and Redshank will be found in the addenda.

No system of classification has been introduced, it being deemed unnecessary in a work of this nature. In the sequence of species I have followed the arrangement in the fourth edition of Yarrell's History of British Birds, which is perhaps more generally known among British Ornithologists than any other work; and for the same reason I have also, without exception, adopted the generic and specific names used in that work.

O. V. A.

BLOXHAM, OXON.

May $3 r d, \mathbf{1} 889$. 



\section{IN TRODUCTION.}

XFORDSHIRE is bounded on the north-west by Warwickshire, on the north-east by Northamptonshire, on the east by Buckinghamshire, on the south-east and south by Berkshire, and on the west by Berkshire, Gloucestershire, and part of Worcestershire.

In shape it is very irregular, its length being about fiftytwo miles, and its breadth varying from seven to twentyseven miles. It is distant from the sea at Bristol, or rather Portishead, its nearest point, about thirty-five miles.

It has an area of $483,62 \mathrm{I}$ acres, of which, according to the Agricultural Returns for I 883 , about 417,500 are under cultivation, some 154,000 being permanent pasture, and the remainder under corn, green crops, and rotation grasses.

In Capper's Topograplical Dictionary (1829) the area of the county is understated, and for this reason comparisons between the then and present condition of the county are not easily made. But it is evident that while, even under the new survey, giving the larger area, the amount of wood and waste is stated as nearly 4000 acres less than at the earlier date, a very large extent of permanent pasture has been broken up within the last fifty or sixty years, the arable land being estimated in Capper's work at about 100,000 acres less, and the pasture at nearly 80,000 more, than at the present time.

It will be seen from this that the county generally is in a high state of cultivation.

In the northern division we have a succession of small valleys. The streams flowing through each are bordered with meadows more or less liable to flood; the slopes on either side are under pasture; the fields small rather than large, divided 
by tall thick hedges studded with an abundance of hedgerow timber, the elm being the most numerous tree, and a characteristic feature in the landscape. The intervening high grounds consist chiefly of arable land with small low hedges and less timber. Woods are nearly absent, but small spinneys are scattered freely over the district. It is a kind of country eminently adapted to the requirements of our smaller birds, the summer migrants finding shelter suitable to their retiring habits in the thick hedges, and the Finches and Buntings having every facility for nesting in summer and a sufficiency of arable land to range over for food in winter. The tall hedges too produce an abundant crop of haws and other hedge fruits, attractive to the migratory Thrushes in autumn and winter; while the alluvial meadows present a vast area of feeding-ground to Wagtails, Pipits, Starlings, Rooks, Crows, ete., as well as some waders, in their partlyflooded condition, and to waterfowl when still more submerged.

In the north-west the country is more open and undulating, with fewer valleys and long gently-rising slopes swelling to rounded hills-the outlying spurs of the Cotswolds. The land, except just in the valleys, is arable, with big stony fields and small hedges, the latter being often replaced by dry stone walls. IIedgerow timber, so abundant over many parts of the county, is scarce here, making the country cold and bleak in winter and extremely hot and dry in summer. Especially about Rollright, on the high ground where stands the wellknown Druidical circle, the Rollrich Stones, it is peculiarly bleak. The beech, rare in the north, appears here on the limestone more commonly. There are, however, warm woods of oak, beech, spruce, and larch here and there-Bruern, FyfieldHeath and Churchill-Heath Woods, as well as those about Sarsden.

On the higher corn lands Larks are abundant, and the Corn Bunting finds a congenial home; the heathy edges of the woods are attractive to the Grasshopper Warbler, Whinchat, and Limnet, while in the more sheltered valleys there is no lack of Warblers. 
From Fyfield, and the valley of the Evenlode at Shiptonunder-Wyehwood, to Burford in the valley of the Windrush, stretches a wide expanse of high ground, formerly grassy down, but now entirely under the plough. A bleak, monotonous tract, in which hedges and hedgerow timber are alike absent; the stony fields are separated by grey stone walls, and the only trees present are a few isolated clumps which are landmarks for miles. Bird-life is scarce up here, the Lark being' the most abundant species. Burford itself lies in the sheltered valley of the rapid Windrush, where green meadows, hedges, and elms relieve the eye.

North-eastwards, stretching with scattered woods to Ditchley, near Kiddington, and the great Park which Henry I enclosed at Woodstock, we have the remains of Wychwood Forest; but only about Leafield and Cornbury is there any large extent of woodland at the present day.

South of the valley of the Windrush, between Burford and Witney (the river bending south-east after passing the latter place), the ground again rises, and is intersected with little valleys rumning south-eastward to the low ground along the upper reaches of the Isis.

From Kelmscote, along the banks of the Isis past Bampton to Stanton Harcourt, the land is wet and low-lying, and comprises some of the most lonely reaches of the river. Previous to the time of the enclosures the area bordered by the river from Radcot Bridge to Newbridge contained some thousands of acres of unenclosed and undrained common land, a great part of which for some time in each year consisted of spongy morass intersected by backwaters of the river. Here was a paradise for the wildfowl-shooter. But an Enclosure Act was passed in 1848 , and a Drainage Act in $\mathrm{I} 866$, and the glories of wildfowling soon passed away. Yet when the Rev. J. W. B. Bell came to Aston in 1874 he found many relies of the old days in the cottages and farm houses; a curious wicker stalking-horse, under cover of which the ducks were approached, long antique duck-guns, some of which had been converted from flint-locks, and stuffed specimens of uncommon waterfowl. 
Rich meadows, growing heavy and luxuriant crops of haygrass, divided by tall, thick hedges, now take the place of open marsh; but the country has still a character of its own. The scarcity of trees, save for rows of poplars, with here and there an ash, and the long lines of willows bordering many of the meadows, cannot fail to strike the observer coming down into this broad belt of flat meadow from the more varied scenery about Witney. Several streams converge about Tadpole Bridge, and wide, deep ditches, growing the beautiful Water Violet (Hotonia palustris), are not infrequent. The Sedge Warbler is naturally an abundant bird here, and the willowand reed-grown banks of the Isis shelter many pairs of the searcer Reed Warbler, while over the surface of the river the Sand Martins are constantly gliding and hovering. Peewits breed commonly in the rougher meadows in pasture, the grating call of the Corncrake sounds from the long grass, and Herons may generally be seen.

This belt of flat alluvial meadow, although becoming narrower in extent and less marshy in character, is continued down the stream past Godstow,

6 . . through those wide fields of breezy grass

Where black-wing'd swallows haunt the glittering Thames,'

to Oxford, widening out before reaching the city to form the large wet common known as Port Meadow.

Oxford must have been the scene of the earlier observations of not a few of our British ornithologists, and many will be able to say with the late Mr. A. E. Knnx, "Again, as in bygone days, are we wandering together on the swampy flats of Port Meadow, or exploring the sedgy banks of the Isis near Sandford Lasher, almost forgetting our hurriedly-moored skiffs in a prolonged search after the nest of the water-hen, or the airy fabric of the reed-warbler. Once more are we seated beneath the old rook-trees in Christ Church meadow, and congratulating the dusky proprietors of the village overhead that the fortunate settlement is within the protective influence of academic laws.' (Ornitholoyical Rambles in Sussex?, pp. I-2.)

Oxford itself, with its quiet, shady gardens and smooth, 
grassy lawns, its old trees, rivers, meadows, and shrubberied 'Parks,' is attractive to many birds. Around her walls the scenery is very diversified, low-lying meadows contrasting with higher corn lands and the elevations at Headington and Shotover Hill. The latter still retains much of its original character, one side presenting a rough and broken slope, clothed with bushes, gorse, and bracken.

To the east and north-east of Oxford the country is wooded; beyond, in the latter direction, lie 'the deep plains of Otmore, often overflowed in winter' (Camden). Otmoor proper, a great low-lying tract, through which meanders the sluggish river Ray, is represented on Bryant's map of Oxon, made from a survey taken in 1823 , as a wide stretch of common land, crossed only by the remains of an ancient Roman road and the bridle track from Horton to Studely and Charlton. It was enclosed about the year 1837 , and, though never properly drained, a system of large ditches has rendered it considerably drier than it formerly was. At the present day what is known as Otmoor consists of some two or three thousand acres, which (save in exceptionally dry seasons) are under water all winter, often also in summer, and are never very dry at any time (T. W. Falcon in lit.). Large numbers of wildfowl used to resort here in winter, affording employment to professional gumners, a few of whom still remain. Even nowadays Otmoor is ammually visited by considerable quantities of fowl, which in some seasons are even abundant, and many ducks of various kinds, and other birds, are shot there, and sent up to Oxford market.

At Boarstall, situated only about half a mile over the borders of the county, in Buckinghamshire, south-west of Piddington, there is an old-established decoy. The pond, about two acres in extent, is in the middle of a small wood, and is furnished with four pipes. When the Rev. B. D'O. Aplin visited the deeoy he was informed that about three thousand ducks were taken in the season of $1882-3$; they were chiefly Mallard and Teal, with a few Wigeon, Shoveller, and Pintail. All the fowl taken at Boarstall are doubtless drawn from the extensive feeding-ground of Otmoor. 
Southward of Oxford, broad alluvial meadows, rich in verdure in summer, and damp and liable to floods in winter, backed in places by wooded slopes, border the Isis as far as a little below the spot where it receives the waters of the Thame; here the Chiltern range begins to affect the country.

In view of the recent Act restricting shooting on the river, it is to be hoped that the Coots, Moorhens, Dabehicks, Wildducks, etc., may again increase on the Thames. Formerly they were decimated by the numerous 'pot-hunters' who came up' the river in boats, shooting at every bird they saw.

Across the narrow part of the county, east of the Thame valley, and following the trend of it in a north-easterly direction, a belt of more or less flat land lies at the foot of the chalk-hills.

The southern division includes, roughly speaking, that part of the county lying south-east of a line drawn from the 'Thames at North Stoke north-eastwards to Chinnor. In this district a narrow border of meadow lies in places between the river and the Chiltern range of chalk-hills, but generally the arable fields of the open wold slope gently down to the river's banks; here and there the slope is steeper and rooded. The Chiltern IIills are partly open sheep-down, dotted over with juniper bushes, on which here and there the plough has made inroads on the shallow soil, and partly covered with beech wood interspersed in parts with the oak and white beam, and with plantations of conifers; here and there on the top of the hills are patches of rough, broken ground, partly clothed with ling, juniper, ete. Itere the local Woodlark finds a home, and the soil is warm enough to encourage the Cirl Bunting; while the Dotterel has not yet ceased to visit some of the hills, and the Stone Curlew still breeds sparingly in at least one locality. The open chalk-downs, with their scattered juniper bushes are of course favourable to the Stonechat, Whinchat, and Wheatear.

Scattered over the county, here and there, are little isolated, and often decreasing, tracts of heathy land; remnants of the wide-stretehing heaths once covering a considerable portion of the county. Such exist at Cottisford, Hand- 
borough, Hanwell, Shotover, and various spots among the Chilterns. The few remaining acres of Wigginton, or Tadmarton Heath, may be taken as an example. Here the bracken, broom, and gorse flourish, and the ling still surrives in patches; and here the Stonechat, Whinchat, and Grasshopper Warbler breeding annually, the abundant Linnets, and the Sand Nartins with their tumnels bored in the soft, ferruginous sandstone in the face of the pits, give the place a character of its own. Inclosure and tillage are gradually breaking up the heaths, and they will soon become things of the past.

Among the more interesting spots in the county, from an ornithological point of view, is Clattercote Reservoir, a sheet of water some twenty acres in extent. Surrounded on three sides by thick hedgerows, and well furnished with rushes, flags, and other water-plants at the sides and upper end, it forms an attractive resort for ducks and other waterfowl. The following water-birds have reared their young there in recent years, viz. Wild-duck, Teal, Coot, Moorhen, Great Crested Grebe, and Little Grebe; the Kingfisher and Water Rail inhabit the pool but have not been detected breeding there, while the Peewit, Reed Bunting, Sedge and some other' species of Warblers have their nests in the surmunding undergrowth, or in the immediate vicinity. I have also observed the Reed Warbler, but it is scarce. At the close of summer the waterfowl with their young throng the water, and mingle with other's which visit the pool at that season, especially if the water is low. An extract from my journal relating to the $3^{\text {rd }}$ and 4 th of August will give some idea of the bird life to be seen at that season. The water was very low, and, at the upper end, mud flats extended far beyond the reed-beds; little streams trickled through the mud, and some deeper parts formed pools, while the growth of water-plants produced little wet islands. On the mud were nine or ten Herons, in every possible attitude. Three Green Sandpipers fed along the edge of the water, and at a little distance a couple of Common Sandpipers, while numbers of Moorhens, both adult and immature, were dotted abont over the mud; 
every now and then one of the latter would take fright and scuttle into the reeds. The shallow water was occupied by numerous Coots of all ages, from the adults to the young not yet out of down; out in the deeper water were a few Wildducks and one or two Crested Grebes, and four small ducks, evidently Teal, rose from some part of the water and flew past, on a boy showing himself from one of the fields at the Claydon corner. This of course roused all the fowl, and sent the Herons off in a body; the latter, after flying round for some time, uttering loud croaks, perched on the tops of some neighbouring trees. A Kingfisher perched on the old wooden piles out in the water, and they were occupied later by a Sandpiper. 4th, 6.45 a.m., a bright morning. Eight Herons feeding about the mud. One was wading in a pool of water up to his body; bending forward, with neck drawn in and hent, he suddenly darted out his beak and secured a prey, which he bolted; this was repeated several times. A Green Sandpiper, which had been feeding along the mud edge, rose and circled round for some time, higher than the tops of the highest elms, calling loudly, tul-a-iree-wee tul-a-wee-wee. I was able to make certain that the little ducks seen the day before yesterday were Teal. After I had watched them for arwhile on the sheltered side of the water, now feeding along the edge, now resting in that very upright attitude affected by them, or taking short flights, they rose and flew across the corner of the pool, alighting, to the number of six in the 'spring', in some wet oozy mud too thick for them to swim but too soft to support their feet, when they paddled about feeding and 'guzzling' in great contentment.

The Grey Wagtail, Meadow Pipit, and occasionally the Snipe, the 'Tufted Duck, Pochard, and Golden Eye are autumn and winter visitors to the pool, together with Wild-ducks and Teal in increased numbers; various rare water-birds, and even wanderers from the coast, have also been observed or procured there from time to time.

The large, flat, unenclosed meadow lying along the banks of the Isis north of Oxford, and known as Port Meadow, is noted as the spot where a large proportion of the rarer wading and 
aquatic visitors mentioned in this work have been procured; here in winter, when the meadow is wholly or partially flooded, as it very frequently is, numbers of wildfowl and other birds -Ducks, Teal, Herons, and Peewits, besides countless Rooks, Starlings, Fieldfares, and Redrings, are often to be seen; occasionally rarer visitors, such as Wild-geese, Curlews, and Gulls may be observed.

Our water-meadows in the larger valleys often afford fine sights of wildfowl in winter. At the time of big floods the lower parts of the valleys form a series of shallow lakes, out of which peep patches of higher ground, the upper parts of the hedges, and the heads of the pollard willows. Teams of Duck and coils of Teal dot the water, or wing their nay high overhead, great flocks of Peewits mingled with Crows, Rooks, clouds of Starlings, Fieldfares, and Redwings feed along the flood edge, where here and there the tall, grey form of the Heron may be seen. The Common and Jack Snipe too are found, and sometimes the Wigeon and Golden Plover.

Oxfordshire can boast of more than forty Parks and parklike grounds. Some fifteen of the former contain upwards of two hundred acres. By far the largest of these is Blenheim, comprising some 2700 acres, and not less than ten miles in circumference, which was enclosed by Henry I, and is said by Rouse, the historian, to have been the first walled park in England. Next in size comes Nuneham, r 200 acres, extending for some distance along the east bank of the Isis. Middleton Stoney comprises about 600 acres; Cornbury, adjoining Wychwood Forest, some 500; while Ditchley, Heythrop, and Caversham are each not less than 300 acres in extent.

Heavily and beautifully timbered for the most part, with rich green undulating lawns, little sechuded spimneys, and frequent adjacent woods, these parks possess qualifications eminently adapted to meet the requirements of our woodland birds. The fine sheets of ornamental water also, present in some of them, are attractive to waterfowl, not only those species which breed here, but others which visit us during the winter months.

Oxfordshire was in former times much more rooded than 
at the present day. Camden, describing the county, says, 'It is a fertile country; the lower parts are cultivated into pleasant fields and mearlows and the hills are covered with great store of woods.' (Britannia.) But during the time of the Civil Wars most of the woods were destroyed except on the Chiltern Hills. Plot, commenting in 1677 on the above passage of Camden's, writes, 'The Hills, 'tis true, before the late unhappy Wars, were well enough (as he says) beset with woods, where 'tis now so scarcy, that 'tis a common thing to sell it by weight, and not only at Oxford but at many places in the Northern parts of the shire. And thus it is everywhere but in the Chiltern comtry, which remains to this day a moody tract.' (Nat. Hist. Oxon, p. 5 $\mathrm{I}$.)

It is probable that over a large part of the comty the woods thus destroyed were never renewed, although ornamental timber was planted to a considerable extent and hedgerow trees were encouraged. Wichwood, or Wychwood, was the most extensive stretch of woodland, and was an ancient Royal Forest. 'Hard by,' writes Camden in the latter part of the sixteenth century, 'Wichwood Forest is of large extent, and yet the bounds of it were once much wider: For King Richard the third disforested a great part of Wichwood between Woodstock and Brightstow, which King Edward the fourth had taken into the limits of that Forest, as we are informed by John Rous of Warwick.' (Gibson's edition, p. 294.) That it once extended as far south as Bampton is shown by the old name for that place-Bampton-in-the-Bush. When the 'Wichwood Disafforesting Act I853' (I6 and I7 Tict. cap. 36) was passed, the area of the Forest was stated in the preamble to the Act as 3735 acres.

At the present day the chief woods are those which stretch in a great belt across Mid Oxon, comprising portions of the much diminished Wichwood, consisting chiefly of scattered woods extending to Ditchley on the north and Southleigh on the south, and reaching eastward to the plantations of Blenheim at Woodstock and thence south-east to Wood Eaton, Beckley, Forest IIill, and Waterperry. In the Chiltern district the hills along the whole range from Mapledurham to Crowel are capped 
here and there with nood, part perhaps of that great forest mentioned by Leland reaching from beside Portus Limenus in Kent one hundred and twenty miles westward, 'which,' writes Plot, 'happily falls out to be about this place.' The woods at Nuneham are extensive, and the whole place is heavily timbered. Sloping upwards from one of the most beautiful reaches of the upper 'Thames, Nuneham in early summer, when its rich meadows are golden with buttercups and its trees clad in their freshest green, fairly teems with birds. Stock Doves in exceptional numbers, together with Owls, Kestrels, Jackdaws, Starlings, Titmice, Nuthatches, Green Woodpeckers, and more rarely the Greater and Lesser Spotted Woodpeckers, share the holes and hollows in the old trees in the park. The open woods, rich in undergrowth, abound with Nightingales, Wood Wrens, and all our common woodland warblers, while the yews and other thick evergreens in the gardens and walks, and the beautiful wood of specimen conifers and rhododendrons known as the Pinetum, must be a paradise to the Titmice in winter, and tempt many a pair of the tiny Golden-crested Irens to hang their nests beneath the extremities of the drooping branches. With these exceptions the woods in the county are few, scattered, and generally small, though Bruern, Fy fieldand Churchill-Heath Woods near Kingham are of considerable extent, as also is Worton Wood; and Wroxton, Sarsden, Broughton, Great Tew, and many other parks abound so in timber as to present a wooded appearance.

The elevation of the county is raried, ranging from I 20 to 800 feet. The Thames, where it leaves the county near Henley, is I 20 feet above the sea, its level rising to $\mathrm{g} 90$ feet at Oxford, where it is joined by the Cherwell, and the latter stream attaining an elevation of 300 feet at Banbury. The valley at Kingham near Chipping Norton is not less than a hundred feet higher. In the north of the county, Wigginton Heath rises to a height of about 650 feet, and Eprell Hill to nearly another hundred feet. In West Oxon the high ridge of land on the Warrickshire borders, and the outlying spurs of the Cotswolds, have an elevation of nearly 800 feet. Shotover Hill varies the level about Oxford, rising to about 370 feet 
above the river there. In the south the long range of chalk downs known as the Chiltern Hills, stretching for a distance of nearly sixteen miles, present some imposing heights, rising to nearly 700 feet at Nettlebed, and attaining an elevation of upwards of 800 feet near the Buckinghamshire borders at Beacon Hill.

Oxfordshire is watered by one river, the Isis or Thames, and some score or so of streams of more or less importance, besides a number of minor streamlets, all of which, with two exceptions, empty themselves into the Thames. The Stour and Ouse take their rise in the county but leave it after a few miles' course. Oxfordshire indeed has been said to be the best watered county in England. Plot writes, 'though Oxfordshire almost in every part.... doth produce corn of all sorts plentifully enough ; yet it has much more cause to brag of its meadows, and abundance of pastures, wherein (as in rivers) few countrys may be compared, perhaps none preferr'd.'

The Isis touches Oxon at Kelmseote, and afterwards divides this county from Berkshire until at Remenham the left bank of the river passes into Bucks. The more important streams which it receives in its course are, successively, the Leach and the Windrush, rising in the Gloucestershire wolds, which, rapid, clear, and stony, differ from the rest of our streams with their muddy banks and bottoms and often sluggish current; the Evenlode, with its tributaries the Glyme and Dorne; the Cherwell, flowing from the extreme north of the county, and receiving in its course to Oxford numerous additions to swell its volume, among others the Sorbrook, the Swere, and the sluggish Ray, which meanders through Otmoor; and lastly the Thame, after which last junction it properly assumes the name of Thames. South and east of this no streams of any size exist in the county, the Chiltern district being badly supplied with water in all parts except in the immediate vicinity of the Thames.

'And what sedged brooks are Thames's tributaries.'

The amount of water brought down by the streams varies greatly with the seasons. In summer they are often very 
low, but never dry, and their banks allow for a considerable rise in the level of the water during winter floods. In longcontinued wet weather, and when a heavy fall of rain or the rapid thawing of snow brings down a rush of water from the uplands, the meadows along most of our streams are liable to become flooded, often to a considerable extent and with great suddenness and rapidity.

Ornamental water is present in several of the parks, but the only large sheet is the lake at Blenheim (2.50 acres). Clattercote Reservoir is about twenty acres, and Tusmore, Kirtlington, Sarsden, and several other parks are embellished with considerable pools.

The elimate of Oxfordshire is rather dry, and cold in winter, especially on the bleak, treeless uplands, which in summer are often extremely hot.

An interesting account of the topography of the county, from a botanist's point of view, with valuable details of the geology, drainage, and meteorology, will be found in the introduction to Mr. G. Claridge Druce's very complete Flora of Oxfordshire.

The ornithological literature of Oxfordshire, so far as I have been able to trace it, is not extensive, but dates back to the latter part of the seventeenth century. 'Oxfordshire,' writes Camden in I586, 'abounds with all sorts of game both for hunting and hawking;' but when Childrey in I66I brought out his 'Britannia Baconica,' or the Natural Rarities of England and Wales, in which work he appears to have collated all the published accounts of the natural history of each county, he dismissed Oxon in a few lines, making no mention of its zoology, and it is not until 1677 that the ornithology of the county seems to have received any attention. In that year appeared The Natural Ilistory of Oxfortshive, by Robert Plot, a folio work dedicated to Charles II. Chapter vii, in which the author treats 'Of Brutes,' contains a few notes upon birds, which will be quoted under the heads of the several species to which they refer. A second edition appeared in 1705 . Dr. Plot was elected one of the Secretaries of the Royal Society in I68I. He was a friend of Pepys and 
Evelyn, and the latter tells us in his 'Diary', that, when at Oxford in 1675, he went to see 'that rare collection of natural curiosities of Dr. Plot's of Magdalen IIall, all of them collected in this Shire.' The collection comprised, among other things, certain 'foules,' but what these were Evelyn does not say ; probably the Cormorant, killed from St. Mary's steeple, and the white Linnet, given to him by Mr. Lane of Deddington, were included in the collection.

In the account of Oxfordshire birds by the Revs. A. and H. Matthews, to be more fully mentioned below, the authors refer to 'an old manuscript list of birds, collected by the late Dr. Lamb of Newbury, extending as far back as the latter part of the last century,' which was lent for their perusal by Dr. Tomkins of Abingdon. Under the title of Ornithologia Bercheria the list was, some years afterwards, printed in the Zoologist ( 880 , pp. 31 $3-325$ ), the Editor furnishing the following information relating to it:- 'This list, it would seem, was originally intended for publication in the "Transactions of the Limnean Society," and was forwarded for that purpose, about the year I8I4, to Thomas Marsham, who was then Treasurer of that Society. For some reason, however, it never appeared, and the original MS., as we learn from the Assistant Secretary, was either lost or mislaid during the subsequent removal of the Society from the rooms formerly occupied in Soho Square. A copy, however, is in the possession of the Rev. W. Smith Tomkins of Weston-super-Mare, who has kindly placed it at the disposal of the Editor for publication in the 'Zoologist.' This list refers to Oxfordshire, inasmuch as some of the birds recorded in it were procured on that part of the river Thames which divides this county from Berkshire, such occurrences belonging therefore with equal propriety to both counties. It is also interesting to compare the condition of the avifauna, at the beginning of the last century, of the neighbouring parts of this border county, which would probably differ very little from that of the district treated of in the present volume at the same time.

An account of the Vertebrate Animals of the district is appended to the Mistory of Banbury (I84I), by Mr. Alfred 
Beesley. It is little more than a bare list of species, and includes 109 birds. The author acknowledges assistance from Mr. James Loftus, formerly of Banbury, Mr. M. Jessop and Mr. T. Abbott of Banbury, and Mr. J. Busby of North Newington. In the Zoologist for I 849, and the following year, appeared a series of articles by the Revs. Andrew and Henry Matthews, entitled The Birls of Oxforlshire ant ats neighbourhoorl. The list comprised 232 species, but of these nine must be excluded from the census of Oxon birds, as the examples upon which their title to inclusion rests were procured in the neighbouring parts of Berkshire or Buckinghamshire. The authors wrote from Weston-on-the-Green, in the Otmoor country, where they had been resident for many years, a district most favourable for observing the more uncommon wildfowl which visit us in winter; the list is accordingly very rich in records of this group of birds. For this reason, and from the fact that the writers' experience goes back to the time when the country was less carefully drained than it is now, and to the time when not only were the ordinary wildfowl far more numerous than at present, but when the Kite, the Buzzard, the Raven, the Harriers, and the Bittern were not infrequently met with, the Messis. Matthews' excellent account of our birds is of especial interest and value to the county faunist. In 1876 and $1877 \mathrm{Mr}$. C. M. Prior contributed to the Bantury Guarlian a series of articles upon the 'Birds of North Oxon.' In I 882 was published a pamphlet, entitled A List of the Birds of the Banbury District, written by the author in conjunction with his brothers; the list, which included I 80 species, applied mainly to North Oxfordshire. In June, I886, appeared A Iear with the Birls, by an Oxford Tutor. A second and enlarged edition, in which the author, Mr. W. Warde Fowler, revealed his identity to the public, was issued before the year was out. This edition contains a list of the birds observed within a radius of four miles around Oxford during the three preceding years, including 104 species. The present writer is indebted to this work for much useful information relating to the birds in the neighbourhood of Oxford, and in the north-west of the county, contained in 
the chapters on the birds of an English city and a Midland village.

Such are the only works treating of the ornithology of Oxfordshire especially, which I have been able to discover, but occasional notes (chiefly records of the occurrence of rare species) are scattered through, and have been culled from. Merret's Pinax Rerum Naturatium Britannicamm (I666), White's Natural History of Selbome (1789), Daniel's Rural Sports (1807), Pennant's British Zoology (I812), Montagu's Omithological Dictionary (1802), and Supplement (1813), Yarrell's History of British Birds (4th edition), Harting's ILandbook of British Birls, Morris' History of British Birls, Knox's Ornithological Rambles in Sussex, Clark-Kennedy's Birls of Berkishive and Buckinghamshive, A Catalogne of the Birds in the British Mnsenm, The Zoologist, The Tis, Loudon's Magazine of Natural History, The Annals and Magazine of Natural History, ete.

Besides these published sources of information, I have received a large amount of assistance from numerous friends and correspondents, who have contributed valuable information in the readiest manner. Lord Lilford has kindly sent me a reprint of his communications to the Zoologist, which embody his notes on birds made during the time he was in residence at the University. Mr. W. Warde Fowler has contributed a list of the birds observed by him in the neighbourhood of Kingham, supplemented subsequently by much information by letter relating to that district and to Oxford. I am also greatly indebted to him for kindly perusing my manuscript, and for the great assistance generally which he has rendered in the preparation of this work for the press. The Rev. H. A. Macpherson, and Mr. A. H. Macpherson, during their terms of residence at Oriel and Trinity, devoted much attention to the ornithology of the country round Oxford, the result of which was regularly reported to me; they have also rendered much service by furnishing references to, and extracts from, the older publications, periodical and otherwise. To Mr. E. W. Harcourt I am indebted for notes upon the birds breeding in or visiting Nuneham Park, and of 
the neighbourhood of Stanton Harcourt. The Rev. A. Matthews has obligingly answered numerous questions relating to the birds of the county previous to his leaving it in I 854 , thus considerably augmenting his papers in the Zoologist. Mr. W. H. Warner, formerly of Standlake, has furnished me with considerable notes of the more uncommon birds occurring in that neighbourhood. Mr. T. Beesley has kindly lent for my perusal an annotated copy of the History of Banbury list, and also furnished extracts relating to rare birds found in the neighbourhood of Banbury, from his note-books, which extend back over a period of more than forty years. To Mr. G. Arnatt, of Stanton Harcourt, I am indebted for full particulars of the Oxfordshire speeimens in his interesting collection, and for notes on the former abundance of some species now rarely met with. My brothers, Mr. F. C. Aplin and the Rev. B. D'Oyly Aplin, the former at Bodicote, and the latter during a two years' residence at Chinnor in the Chiltern district, have made valuable notes on the ornithology of their own neighbourhoods, thus covering ground which I could not have under my own observation. Mr. J. E. Kelsall of Balliol College has obligingly looked up references in several works and periodicals in the British Museum. From Professor A. Newton, the Rev. H. Holbech, Mr. J. Whitaker, Mr. J. R. Earle, Mr. J. E. Harting, the Rev. Murray A. Mathew, Mr. Alfred H. Cocks, the Rev. J. W. B. Bell, Mr. E. Bidwell, Mr. W. Newton, jun., Mr. A. B. R. Battye, Mr. C. M. Prior, and numerous other correspondents $I$ have received valuable notes. For the great assistance thus rendered, without which it would have been impossible for me to complete this work, my warmest thanks and acknowledgments are tendered. My thanks are also due to our county taxidermists, Mr. W. C. Darbey of Oxford, MIr. W. Wyatt of Banbury, Mr. Coombes of Chipping Norton, and Mr. Wells of Burford, to whom I am indebted for the opportunity of examining and recording the greater number of the rarer avian visitors which have been procured in the county during the past few years. Of all my correspondents, there were few whose letters were more interesting than those of the late 
Rev. T. W. Falcon, Rector of Charlton-on-Otmoor; he must have been possessed of rare powers of observation, and the cessation of our correspondence in I882, consequent upon a severe illness from which he never fully recovered, was a great loss to this book. It is with regret (although he was personally unknown to me) that I pen this tribute to the memory of an Oxfordshire field ornithologist, in the place of the acknowledgment of much information imparted which could not have been too warmly expressed.

Oxfordshire, in the character of its ornithology, most nearly resembles the eastern side of southern England. Such species as have their head-quarters in south-east Britain, but are more or less uncommon in the north or west, e.g. the Hobby, Nightingale, Chiffchaff, Lesser Whitethroat, Tree Sparrow, Nuthatch, and Lesser Spotted Woodpecker, are perhaps as abundant with us as in any part of the kingdom; the Red-legged Partridge is well established and, in many parts of the county, numerous; we get too the north-eastern Brambling as a regular winter visitor, frequently in large flccks. We are, however, situated too far inland to participate, otherwise than sparingly, in the representatives of certain species which in winter may at times be said to swarm on the east coast, e.g. the Twite, Snow Bunting, Hooded Crow, and various waders.

On the other hand, the south-western Cirl Bunting is decidedly scarce, while of some birds which are resident in, or regular summer visitors to, the west and north, the Grey Wagtail is with rare exceptions only a winter visitor, the Dipper is almost of accidental occurrence, and the Ring Ouzel, Pied Flycatcher, and Common Sandpiper are merely passing visitors of more or less uncommon occurrence.

The changes in our avifauna which have taken place within the century may be briefly referred to. We have first to deplore the almost total disappearance of the Kite, Buzzard, Harrier, Raven, and Bittern, which at the commencement of that period were either resident in some numbers or frequent visitors, but are now only of more or less rare and occasional occurrence. It is possible that the Snipe, Red- 
shank, Black Tern, and some species of wild-ducks which are now only migrants or visitors, may have bred at one time on Otmoor before it was enclosed. The trips of Dotterel, once seen regularly on our hills and downs on their passage in spring and autumn, are now more rarely observed and much less widely diffused, and the Stone Curlew no longer rears its young on the stony fields on the hills about Sarsden and Chadlington, and has probably entirely ceased to breed in the county save in one locality in the extreme south. The Quail perhaps visits us less often, and in fewer numbers, than in former years-a fact observed in many parts of England. The Bearded Tit, which probably at no very distant time inhabited the reed-grown margins of the Isis, has entirely disappeared. The Nightingale, from some unknown cause, has within the last twenty or five-and-twenty years greatly decreased in the north of the county, and is now extremely scarce where formerly it used to be heard every year in some numbers. The Barn Owl holds its own, but with difficulty, in the face of the persecution to which it is subjected; while the Goldfinch, which as a breeding species had a few years since become very scarce, has within the last four or five years (probably in part at least owing to the Wild Birds Protection Acts) been steadily increasing again, and at the present time is fairly numerous. The Red-legged Partridge, which was very rare fifty years ago, is steadily increasing and spreading, and is now generally distributed over most parts of the county. The Hawfinch is increasing, and may now be considered a permanent resident instead of a rather rare winter visitor only. The Woodpigeon or Ringdove has increased slightly of late, and the Starling and Sparrow to a considerable extent, especially the former. The increase of these two birds must in part at least be attributed to the destruction of their natural enemies the hawks, the Sparrow Hawk especially being much scarcer than it formerly was. There has been of late years a great diminution in the number of wildfowl visiting us in winter, consecquent upon the more perfect drainage of the meadows, and of Otmoor. The wildfowl remaining to breed have become numerically 
stronger since the successive passing of the 'Wildfowl Preservation Act $(1876)$ ' and the 'Wild Birds Protection Acts I 880 and I88I,' previous to which hardly any ducks were bred in the county except in the few places where they were closely preserved.

It may be admissible to say a few words here upon the subject of game preserving, i. e. that branch of it which consists in destroying so-called winged vermin. Fortunately for the naturalist and the lover of country sights and sounds, this has not been earried to such a length in Oxfordshire as in some other counties. To a certain extent game preserving is practised in the comnty, chiefly in the parks and adjacent woods pertaining to some of our large residential properties, and also, in a lesser degree, in the surrounding country. Here not only every pair of harks which attempt to rear their young are doomed to speedy destruction, but numbers of harmless species are also condemned. In such places the keeper's motto is but too often 'All is vermin that is not game,' the result of, perhaps excusable, ignorance of the true nature and habits of birds. It is no doubt almost too much to expert keepers to permit a hungry brood of young Sparrow Hawks to be reared in the vicinity of the Pheasant coops. Still one cannot help thinking that if the coops could, during the few weeks the broods are young, be watched by a boy in the daytime, it would be desirable to spare a few of these active little hawks for the purpose of preventing the undue increase of some of our smaller birds, which form their favourite prey; and also that they might, as they undoubtedly would, kill down those Partridges which, defieient in strength and constitution, tend, if allowed to survive, to propagate a race of weakly birds. By all means let those inveterate ego-stealers, Crows, Magpies, and Rooks, be kept within bounds (not exterminated). The last-named are in dry seasons most destructive to eggs, and, little as the owner may suspect it, the vicinity of a large Rookery is probably far more inimical to the increase of Partridges than the presence of a few pairs of Sparrow Hawks. With the exception of those birds here named, the rest of our avifauna 
can plead exemption from the title of vermin. It has certainly been proved that the mouse-eating Kestrel will occasionally carry off young Pheasants from the coops, but such is not their rule of life, and it is hard that the offences of a few individuals should seal the fate of all the members of a beneficial race. Caring little indeed, during the greater part of the year, even for small birds, these useful little harks prefer mice to any other food, and their elegant forms and graceful evolutions, when beating over the fields in search of their favourite quarry, are one of the most pleasing sights of the country side. Yet how often does their variegated plumage grace the keeper's gallows! Sad too it is to see the soft feathers of Owls fluttering in the air as they hang side by side with other so-called malefactors. It may safely be affirmed that no well-sustained charge of any but the rarest poaching can be brought against Owls. Flying by night, when young game-birds are, or ought to be, safely housed, how can they, if they would, carry off young Pheasants? A tiny leveret or young rabbit may occasionally be seized, but their prey is rather the rat, than which no worse vermin exists, and keepers should protect them.

Let the protection of our landed proprietors be invoked in favour of these and other harmless birds. Let them instruct their keepers that they shall, while keeping the egg-stealing. Crow family within bounds, and banishing Sparrow Hawks from a too near proximity to the rearing coops, give free quarters to other birds. Let them tell them that Cuckoos and Nightjars are not hawks, though they look like them, and that the former do not turn to hawks in the winter-a fact about which, I believe, some uncertainty still exist: in Oxfordshire; that Kingfishers are a desirable ornament to their pools and streams, and that Woodpeckers are not destructive to game. Above all let them prohibit the use on their properties of those most deadly and destructive contrivances, pole-traps, which for every hawk caught in them are answerable for the death of ten innocent birds. So shall their head of game be as large as ever, their parks and woods shall afford them many additional interesting sights, and they 
will assist in preserving our native fauna for the pleasure of future generations.

It is a satisfaction to add that there are in the county landowners to whom it is quite unnecessary to make these suggestions, and whose demesnes, while affording a sufficiency of game, abound also with the more common woodland species, and are not only the favoured haunts of some of our rarer birds, but also harbour many a pair of Owls and Kestrels.

The present account of the Birds of Oxfordshire comprises 242 species, in addition to six species the occurrence of which is considered doubtful. The former number is made up of 60 Residents, 7 I Periodical Migrants, and II I Oceasional or Accidental Tisitors. It must be here remarked that some species, numbered with the occasional visitors, occur with a regularity almost sufficient to warrant their inclusion among the periodical migrants, and it has been found impossible to draw the line between the occasional and accidental visitors. In the number of species found within its borders, Oxfordshire compares favourably with other inland counties. Middlesex is accredited with 225 species by Mr. J. E. Ilarting, Nottinghamshire with 238 by Messrs. Sterland and Whitaker (a few more species have, however, been recently arded to this county list by the latter gentleman), Wiltshire with 235 by the Rev. A. C. Smith, and the counties of Berkshire and Buckinghamshire together with 225 by $\mathrm{Mr}$. A. W. M. Clark-Kennedy. No less than Io3 species have been known to breed in Oxfordshire within the present century; but of these, five are either extinct as breeding species or have only bred accidentally, and six more have done so only very rarely, leaving 92 as the number of species which breed annually within the limits of the county. 


\section{THE BIRDS OF OXFORDSHIRE.}

\section{THE WHITE-TAILED EAGLE.}

Haliceëtus albicilla.

Tre White-tailed Eagle has occurred in one instance in Oxfordshire, namely at Henley-on-Thames, a few years previous to $\mathrm{I} 849$. (Zoologist, p. 2594.)

\section{THE OSPREY.}

Pandion haticeëtus.

Tru Osprey is an occasional visitor. The Messrs. Matthers record that "within the last few years three specimens of the Osprey have been killed near Oxford; one of these was shot in Nuneham Park, and is now in the possession of $\mathrm{Mr}$. Harcourt' (Zoologist, p. 2594). Dr. Lamb mentions the occurrence of one at Pangbourne on the river boundary of the county (Ornithologia Bercheria). An Osprey haunted the Isis in the neighbourhood of Bablock-Hithe Ferry, near Stanton Harcourt, in September, I887, and was sereral times seen by the ferryman to dash into the river in pursuit of fish. Mr. G. Arnatt tells me that another was seen in the same neighbourhood a few years previously.

\section{THE ICELAND FALCON.}

Falco islandus.

The Iceland Falcon is a rare visitor. The Messrs. Matthews had an excellent opportunity of observing one of these magnificent Falcons in the parish of Sherbourne, their 
account of which is here reproduced. 'On Sunday, the Ioth October, I847, near Tetsworth, in this county, we observed a large bird sitting in a field adjoining the turnpike road: on a nearer approach it proved to be a very fine Gyr-Falcon, in the act of devouring a Woodpigeon. He was in no way disconcerted by our attention to him, but finished his meal, and then flew up into a small tree, where he cleansed his beak and talons with the utmost composure. We had been watching him for several minutes at the trifling distance of sixtyfive paces, and had enjoyed every opportunity of secing him to advantage: he was in very fine condition, apparently in the plumage of the second or third year. Unless he was much pressed by hunger, it would be difficult to account for his tameness on this occasion; for within a few days we again met with him near the same spot, but he took good care to keep beyond the range of our guns.' The distinctions between the forms of northern white Falcons were not at that date fully recognized, and the specimen in question was recorded under the name Gyr-Falcon, but the Rev. A. Matthews has recently informed me that it was an Iceland Falcon. Dr. Kirtland gave the same writers information of a specimen, in immature plumage, which was shot a few years previously near Henley-on-Thames. (Zoologist, pp. 2594-5.)

\section{THE PEREGRINE FALCON.}

Falco peregrimus.

Tire Peregrine Falcon, so much prized for the sport of Falconry in former days, is an occasional visitor from autumn to spring. The Hon. T. L. Powys (now Lord Lilford), in the Zoologist for 1852 , records a fine young bird shot in Blenheim Park in the previous November, and in a note, dated February, I 853 , in the same periodical, he mentions having lately seen two or three in the neighbourhood of Oxford. An immature example was shot at Waterperry about the month 
of October, I879 (H. A. Macpherson), and in the following January an adult male was shot close to Banbury, and came into my bands in the flesh. In the summer of 1882 , as Mr. W. W. Fowler informs me, a Peregrine was seen flying over


following year I saw one in the Sorbrook meadows near the junction of that stream with the Cherwell. Flying up the valley it made a stoop over a tree in which a number of Woodpigeons were sitting, from which the latter flew up with an unusually loud clatter of wings; the Falcon did not strike at them, but after sailing round the tree once or twice, settled on a dead bough. In January, 1888 , I examined in the flesh a male in first plumage which was shot between Banbury and Williamscote, and on the 3 rd of the same month a very fine adult female was killed at Stanton Harcourt; this is now in the collection of Mr. G. Arnatt, who also possesses a pair which he shot at the same place some thirty years ago-the female being killed in the act of striking a pigeon. He tells me that Peregrines occur in that neighbourhood in most seasons, haunting the meadows in pursuit of the wildfowl in the daytime, and retiring to Tar Wood.

\section{THE HОВBY.}

\section{Falco subbuteo.}

The Hobby is a summer visitor, probably of annual occurrence. In some seasons several specimens have been shot, as for instance in 1848 , when two young and two old birds were sent from Woodstock to Mr. T. Prater of Bicester (Zoologist, p. 2297). Although the nest of the Hobby has been discovered in a few instances only of late years, yet from the fact of the adult birds occurring in summer, and specimens in the plumage peculiar to them on leaving the nest later in the year, they must breed with us pretty regularly. A nest with the eggs was taken at North Aston 
Mill about thirty years ago, the old birds being shot, and in 1876 two eggs were procured at Claydon. A young bird taken from the nest in some tall trees at Huskot Mill near Banbury in 1879 lived for some time in my possession, and at Cuddesdon also it has bred twice recently, a nest of three eggs having been discovered in 1884 , and another in 1885 , as I am informed by Mr. E. W. Harcourt. A short distance over the Berkshire borders eggss were taken at Cumnor near Oxford in 1882 (H. A. Macpherson), and near Godstow by Mr. A. B. R. Battye in 1883 .

The following examples of the Hobby have been procured in the county in recent years. An adult at Adderbury in 1876. One near Banbury on the 23rd July, 1877 (Zoologist, r 877, p. 449). An adult male at Tackley, June, I883. An adult male at Oxford, I 7 th July, I884. A remarkably fine old male at Great Bourton on the 2ist of the same month. A young bird at Waterperry, September, I884. A young bird at Wickham Park (one of three said to have frequented the place for some weeks and which no doubt were bred there) on the IIth September, I885. And a young bird at Waterperry in the third week of the same month. On the and September, 1884, when shooting at Bloxham Grove, my brothers and I had a good opportunity of observing the graceful fight of these beautiful little Falcons, one of which was circling rapidly round a clump of chestnut trees, exhibiting its powerful flight and the rapidity and ease with which the sharpest turns were effected to the best advantage, the long pointed wings, which when closed reach quite to the end of the tail, being very noticeable. It was probably in pursuit of insects, which form a considerable portion of its food, but on our nearer approach it flew to a neighbouring avenue, being joined by a second bird.

I have no note of the Hobby having been procured here in winter, as it has in some parts of England; but it is capable of withstanding a considerable amount of cold, and the 
Messrs. Matthews mention that they have several times succeeded in keeping them through the winter in the open air. The young bird in my possession, however, after surviving the severe winters of $1879-80$ and $I 880-8 I$ in an outdoor aviary, died in the following spring, its constitution being probably weakened by the cold.

\section{THE MERLIN.}

\section{Fratco resalon.}

Tre Merlin is a rather scarce winter visitor. The following occurrences within the last few years may be enumerated. In December, I882, an adult male was picked up dead between Banbury and Bloxham, having struck against the telegraph wires. Another fine adult male was shot at Wolvercot on the $x 6$ th of the same month (H. A. Macpherson), and two in immature plumage were procured at Shotover in the same month in 1883: at Oxford a male was procured in January, I886 (A. H. Macpherson). A Merlin in Mr. G. Arnatt's collection was shot at Stanton Harcourt in $188 \mathrm{I}$ on the I6th April, which is an unusually late date in spring for it to occur here. Mr. Arnatt has also other local specimens in immature dress, and tells me that some individuals visit them in most winters. A Merlin was seen in the neighbourhood of Little Tew in the winter of 1882 (W. Wr. Fowler), and $I$ have seen individuals of this species at Bloxham Grove and Great Bourton: a male in the blue dress of the adult was seen close to Banbury on the 3rd March, 1888. A few other local specimens, of which $I$ have been unable to obtain precise information, have come under my notice. The Messrs. Matthews, at the date of whose observations the visits of the Merlin were more frequent, give the date of its arrival as from the fourth week in October to the third in November, but the Rev. H. A. Macpherson has seen a male which was netted at Shotover in September. 


\section{THE KESTREL.}

Falco timmunculus.

The Kestrel is a resident species, comparatively few individuals, however, remaining during the winter. In spite of constant persecution the Kestrel, though less abundant than in some wilder parts of England, is a familiar object, flying quietly over the fields or suspended in mid air, now rapidly beating its wings, now poised almost motionless, save for the broad, expanded tail which regulates its position, as it hangs on the breeze, and then gliding on for a short distance to repeat the performance. It is searching for field mice, which constitute its favourite food, and perchance you may see it drop suddenly, with closed wings, upon one in the grass. Only in severe weather have I seen the Kestrel strike at small birds, upon which it sometimes feeds, but in captivity mice are always preferred before anything else, and it will also eat various insects; earthworms are not discarded, and a Kestrel, turned loose with a clipped wing in a gुarden at Bodicote, might often be seen taking them on the lawn in summer evenings.

Small birds seldom show any terror at the approach of the Kestrel ; its offences against the game preserves are few ; and from the benefits this mouse-eating hawk confers on the agriculturist it should claim protection at his hands.

The Kestrel usually deposits its eggs in the deserted nest of a crow or other bird, but has occasionally been known to breed in a hollow tree; one such nest was found by my friend Mr. J. Rolleston Earle, who took five eggs from a hollow elm near Oxford on the I5th May, I883 (Zoologist, I 884, p. I 48). The young of the Kestrel when first hatched are covered with bluish-grey down.

\section{THE SPARROW HAWK.}

Accipiter nisus.

The Sparrow Hawk is a resident, and although not yet scarce, has become very much less common of late years. 
Bold and daring in its habits, it will resort in winter day after day to some outlying field-barn or stackyard, attracted by the numerous small birds drawn there by the good supply of food, and thus it often falls a victim to the gun brought up for its reception; again, its habit of beating along the hedgerows often brings it unexpectedly on to the gunner as it skims over the top of the hedge. Keepers too wage a bitter war against the Sparrow Hawk, and it must be confessed that its innocence cannot be pleaded, as in the ease of the Kestrel: still it might be spared to some extent if only to keep the Sparrows and Starlings a little in check. In summer the Sparrow Hawk retires to the woods and quiet spinneys to breed, but in winter it is more widely diffused, resorting chiefly to those places most frequented by the various small birds; its apparent greater abundance at the latter season is probably due in a great measure to this.

\section{THE KITE.}

Milvus ictinus.

Tre Kite must have been a common bird in the great woods of Oxfordshire even as late as the early part of the present century, but its extermination began soon after that date, and the rapidity with which its extinction was effected is most remarkable, since little more than a third of the century had passed before the last nest known to have been built in the county was taken.

About the beginning of the century these grand birds might be seen any day by persons taking a country walk (Birds of Berks and Bucks, p. I63), and even over Oxford city itself. Osman, the old bird-stuffer of St. Aldate's, Oxford, then over seventy years of age, told the Rev. Murray A. Mathew about the year I $855-6$ that he had seen three or four Kites sailing in the air at once over Folly Bridge when he was a boy (M. A. Mathew in lit.), and there are still those 
living who can remember when the Kite was a common bird in various parts of the county. An old keeper named Cook, living at Kingham, told me in $\mathrm{I} 887$, when he was over eighty, that when he was a young man the Kite was abundant about Kingham and Sarsden, and you could see several in the air at once over Bruern and Churchill-Heath woods. The Rev. A. Matthews writes to me-'Previous to I 830 Kites bred commonly in the large woods of Oxfordshire: the last nest of which I heard was about that year. I have myself seen at the same minute three Kites flying over the trees in Beckley Wood.' Mr. E. W. Harcourt can recollect when the Kite inhabited Tar Wood, near Stanton Hareourt, and Mr. G. Arnatt tells me he can well remember it breeding annually there fifty years ago. In the Ilistory of Bandury list (1840) the Kite is entered as 'Rare, much more common a few years ago;' and of that neighbourhood Mr. T. Beesley tells me that, when he was a boy, he frequently heard his companions talking of Kites they had seen. Instances of this kind might easily be multiplied. In the extreme south of the county it apparently became rare at an earlier date, since Dr. Lamb wrote of the neighbouring part of Berkshire 'between thirty and forty years ago [i.e. between 1774 and I784], very frequent about Reading, now very rare, having seen one only, in May, I795, near Reading, these twenty-seven years' (Ornithologia Bercheria). It must be remembered, however, that the Kite seems to have seldom wandered far from the shelter of the woods, and might easily have haunted the beech woods on the Chilterns until a later date than is here indicated.

Some year between 1830 and 1840 probably saw the last of the Kite as a resident in Oxfordshire, and but few more years elapsed before it had ceased to appear even as a straggler to the county. The late Mr. A. E. Knox mentions, in 1850 , having' seen it 'many years ago' in Oxfordshire, doubtless while he was in residence at the University (Or- 
nithological Rambles in Sussex, p. 135). Mr. James Dalton informed the Rev. F. O. Morris that a Kite was captured in Blenheim Park (Hist. Brit. Birls, I. p. 65), and this was probably the same individual stated by the Hon. T. L. Powys (now Lord Lilford), in a note dated I th February, 1852 , to be then alive in his possession (Zoologist, p. 3388). Since that date, as far as I know, the Kite has never been procured in Oxfordshire. Fifty years at the most was sufficient to absolutely exterminate a bird common, and even abundant, at the commencement of that period.

Although not occurring actually in the county, a Kite, now in the Rev. Murray A. Mathew's collection, which was shot and stuffed by a barber at Abingdon just over the river in Berkshire, about I 855 , may be mentioned as being probably one of the last of the race of residents procured in that neighbourhood. And as late as I 880 the head keeper at Radley told the Rev. H. A. Macpherson that five years previously he shot a beautiful example of the Kite, describing its tail and expanse of wing. This he sold to a member of Brasenose College for half-a-sovereign. Radley is about a mile over the Berkshire borders, near Nuneham Courtenay.

\section{THE COMMON BUZZARD.}

Buteo vulgaris.

The Buzzard is an occasional visitor, formerly doubtless breeding in the woods, as it was reported to do by Mr. Forrest, an Oxford bird-stuffer, to the Messrs. Matthews, who, however, in their account merely say that it was occasionally killed in the neighbourhood. Thirty years ago, as Mr. E. W. Harcourt kindly informs me, it was a regular visitor to Nuneham Park in the autumn. Mr. G. Arnatt has often seen Buzzards in Tar Wood, Stanton Harcourt, as late as forty years ago, and believed that they bred there at that time. Lord Lilford has recorded an example trapped in Blenheim Park in the winter 
of $185 \mathrm{I}-2$ (Zoologist, p. 3388), and Mr. E. D. Lockmood informed Mr. W. W. Fowler that he saw one in the parish of Kingham many years before. A fine male was trapped at Bletchingdon early in May, I 880, and taken to Mr. Darbey of Oxford, who received two more in the autumn of 1883 from Mid Oxon, the exact particulars of which I have not been able to obtain. On the 5 th December, I 885 , I observed two large hawks, which appeared to be of this species, passing over the parish of Great Bourton; they were flying at a considerable elevation in a south-easterly direction, and proceeded in a succession of circles, the second bird following the first at a short distance, and going through precisely the same evolutions. The last specimen procured in the county was a male shot at Horton on the 5 th February, I886 (A. H. Macpherson, Zoologist, I886, p. I08).

\section{THE ROUGH-LEGGED BUZZARD.}

Buteo lagopus.

Tre Rough-legged Buzzard is a rare visitor. The Messrs. Mathews met with a pair at Weston-on-the-Green, their account of which is here quoted. 'A pair of this fine species was in the habit of frequenting our neighbourhood for many weeks in the winter of $\mathrm{I} 825$, attracted, it was thought, by the snipes which abound at that season in some marshy ground near the village. Over this spot the buzzards might often be seen, generally soaring in the air at a considerable elevation. ... At last the female, a very large and handsome specimen, was canght in a trap in Middleton Park, and kindly presented to us by the Earl of Jersey.' They also received information from Mr. T. Goatley of one shot near Oxford in 1840 (Zoologist, pp. 2595-6). About the middle of November, I 888 , a Rough-legged Buzzard was shot at Murcott, near Charltonon-Otmoor, and sent to Mr. W. C. Darbey for preservation. 


\section{THE HONEY BUZZARD.}

Pernis apirones.

The Honey Buzzard is a rare summer visitor to England, and has occurred in Oxfordshire on three or four oceasions. From an interesting paper on these birds breeding in England, by the late Mr. P. J. Wilmot, communicated by the late Mr. Yarrell to the Zoologist for I 844 , the following particulars are extracted. Early in July, I838, a female Honey Buzzard was shot off her nest in Wellgrove Wood, in the parish of Bix, near Henley-on-Thames, by a gamekeeper of Lord Camoys, named Lowe, and, with two egres taken from the nest, passed into the hands of a birdstuffer at Henley of the name of Hewer. The male bird, which continued to haunt the neighbourhood of the nest, was not long after killed by another of the keepers. The nest, a very large one, was placed in the fork of a beech tree, and was built of sticks of considerable size, with which were intermixed twigs with the leaves on; the lining was composed of leaves and wool. One of these eggrs is now in the Wolley collection at Cambridge, and the skins of the two birds passed into the possession of Mr. Fuller-Maitland. The Messrs. Matthews record that 'In the month of November, I84I, a Honey Buzzard was taken in a very extraordinary manner near Oxford. It had forced its head into a hole in the ground, probably in search of a wasp's nest, and becoming by some means entangled, was captured by a countryman before it could extricate itself.' (Zoologist, p. 2596.) Mr. Thomas Prater, in a note dated the 23 rd September, I 848 , stated that one had been shot near Woodstock a short time since (ib., p. 2297). Two Honey Buzzards were shot in Shabbington Woods about the 23rd September, 1881, one of which was preserved by Mr. W. C. Darbey, who took from its throat some wasps, and found larvae of the same in the stomach. These woods are just inside Buckinghamshire, but they 
adjoin Waterperry Wood in this county, and as the birds were shot so close to our borders, and it is in the highest degree probable that if they inhabited the woods for a short time they would have frequently crossed and recrossed the purely artificial boundary, I have included them in this account.

\section{THE MARSH HARRIER.}

Circus arreginosus.

Trie Marsh Harrier was formerly not uncommon in MidOxon. The Rev. A. Matthews writes, 'I never heard of a nest, but have frequently seen, and sometimes killed, this species' (in lit.). This was prior to 1854 , since which date I have no note of its occurrence in the county. In Dr. Lamb's time $(1814)$ it was the most common hawk in the marshes about Newbury, Berks, but rare about Reading, and it may have bred in those days upon Otmoor.

\section{THE HEN HARRIER.}

Circus cyaneus.

The Hen Harrier is an oceasional visitor of rare oceurrence, probably breeding in the county in former days. The old keeper, Cook, before mentioned, described to me some hawks nearly as large as the Kite which were common when he was young, early in the century. He called them 'Partridge Hawks' and said they flew low over the fields, quartering them regularly up and down like Pointers. These were no doubt of this species. The Hen Harrier was apparently not uncommon in Mid-Oxon forty years ago, the Messrs. Mathews stating that 'males of this species are somewhat rare; the females more frequently met with.' Mr. John Worley of Brize Norton informed the Rev. J. W. B. Bell, in I 888, that he had killed two in the last fifty years, the last about sixteen years previously. One in the grey plumage of the adult male was seen by Mr. W. W. Fowler in the water- 
meadows of the Evenlode, near Kingham, in February, 1882 (MS. notes), and a young male, now in Mr. G. Arnatt's collection, was shot at Stanton Harcourt on the 8th November, 1883. These are the only recent oceurrences of which I have had notice, but a fine old male was seen by a friend of the Rev. H. A. Macpherson on the Berkshire side of the Isis at Cumnor near Oxford on the I5th March, I879.

\section{MONTAGU'S HARRIER.}

Circus cineracens.

Montagu's Harrier is an occasional visitor of rare occurrence. It has been met with near Woodstock, where, as Mr. T. Prater records in a note dated the zzrd September, I848, a female was shot a short time previously, and the Messrs. Matthews received information from Dr. Kirtland of a male, in the plumage of the first year, which was shot on Otmoor in October, $188_{4} 6$, and from Mr. T. Goatley of another, in the same plumage, procured near Thame; they mention also that it had been met with in the neighbourhood of Oxford in January, I 849. (Zoologist, 2596.) An adult male from Oxfordshire is in the British Museum. (Catalogue of Birds in Brit. Mus. I. p. 66.)

\section{THE TAWNY OWI.}

Strix aluco.

The Brown, or Tamny, Owl is a resident, and though most abundant in the woods, is generally distributed in some numbers all over the county where timber abounds. Dark fir plantations, or spinneys, are a favourite abode of this fine species, and its loud hoot may generally be heard in such situations soon after sundown.

The Tawny Owl deposits its eggs in hollow trees, and is an early breeder. At Bloxham Grove, an old elm, which had lost a great limb in a former gale, a hollow being gradually 
formed at the fracture, was felled some years ago. When it crashed to the ground a Brown Owl was found in the hollow, sitting on two eggs: one of these was broken, but the bird was cquite uninjured, and flew away on being liberated, having had a happier fate than the devoted Raven which Gilbert White tells us was whipped down by the twigs and killed when the Raven tree was felled. This occurred on the Ist or 2nd of March, and as the eggs of Owls are not laid on consecutive days, the first egg at least must have been laid in February.

The Brown Owl feeds on rats, mice, moles, shrews, voles, insects, and small birds. It is especially fond of the dor-beetle (Geotrupes vernalis), the elytra of which may often be found in the indigestible portion of its food, which these, in common with all our birds of prey, throw up in the form of castings or pellets. Notwithstimding its useful habits a considerable number of these birls are annually shot by keepers, who do not seem to grasp the fact that when Owls are abroad young Pheasants are not.

\section{THE LONG-EARED OWL.}

Asio otus.

The Long-eared Owl is a scarce resident, and, as such, probably restricted entirely to the woods. In the neighbourhood of Henley it breeds sparingly. (Zoologist, p. 8817.) Trr. C. M. Prior informs me that a pair bred in a cover near Deddington some time previous to I879, and the Rev. H. A. Macpherson examined, in June, I880, two nestlings taken near Charlbury, probably in Wyehwood Forest. A young bird was captured in Coggs Wood, near Witney, in 1883 (Warner, .ILS.), and another, with down still adhering at the nape of the neck, was shot in Lower Worton Wood on the I5th August, I885. Mr. Warner also wrote me word that a young bird was seen, in broad daylight, perched on a fence 
at Stanton Harcourt, on the I $3^{\text {th }}$ June, 1886. In April, I 887 , I detected the remains of two Long-eared Owls on a keeper's 'gallows' in Bruern Wood.

The Long-eared Owl was formerly considered to be merely a winter visitor, the Messrs. Matthews including it as such without further remark. Although, considering its habit of frequenting woods, and its shy and retiring disposition, it is perhaps more common as a resident than is supposed, yet most of the Long-eared Owls killed in winter are undoubtedly migrants; in some years a good many have been brought to the bird-stuffer's' shops at that season, notably in $1879-80$, when the Short-eared Owl, the next species on our list, was also abundant.

\section{THE SHORT-EARED OWL。}

Asio accipitrinus.

THe Short-eared Owl is a winter visitor, a year seldom passing without a few being shot, and in some scasons they are abundant. On the 5th February, I88I, I flushed three together in a rough hassocky meadow near Adderbury, and it is sufficiently well known to some people in the comity to have the local name of 'Marsh Owl.' The earliest date for its arrival in autumn which has come under my notice is the Ist October. During its stay with us it remains hidden in the daytime in thick herbage and undergrowth, and in turnips fields, and is seldom seen to perch upon trees, frequenting open ground, and often haunting low-lying fields and meadows, over which it may be seen flying in the early dusk.

Birds in both the grey and rufous phas s of plumage oecur, but in the former dress they are rare; in the winter of $1879-$ 80, when these owls visited us in some numbers, several grey birds were obtained, but in the following season, when they were even more abundant, all that I examined were warmly coloured. 


\section{THE FAGLE OWL.}

Bubo ignavus.

The Eagle Owl is an accidental visitor from Northern Europe. In the winter of 1833 a male was shot near Oxford, and was examined in the flesh by the Rev. A. Matthews, who, ten years later, had the good fortme to see this magnificent bird alive in the south of the county. In the autumn of 1843 , when travelling by the Great Western Railway, he saw a large bird start from an embankment near Goring, and alight on a willow close to the line; 'as soon as it settled,' he writes, 'it turned its head round, and disclosed to my astonishment the features of an Eagle Owl ; it was then not more than fifty yards away. (Zoologist, p. 2596.)

\section{THE BARN OWL.}

Aluco flammeus.

The Barn, White, or Screech $\mathrm{Owl}$, as it has been variously termed, is a resident species, and, notwithstanding the persecution to which it is subjected, is still very common. Inlike its congeners, the Barn Owl, forsaking the roods and wilder districts, draws near to our homestalls and villages, for reasons to be mentioned presently, and many a village church has its pair of Orwls nesting annually, either in the edifice, or in the old trees which stand round so many of our churchyards. It is so at Chinnor, and Kingham, and many other places; and in this parish they breed ammally in the belfry, the sonorous snoring of the young being plainly heard some distance down the street in the quiet summer nights, and the old birds may be seen in the moonlight skimming swiftly round the angle of the tower, with noiseless ghostly flight, bearing some furry morsel to their expectant young.

It is a great pity that protection is not largely afforded to the Barn Orwl, for no bird confers such benefits on the agriculturist. Some people there are, who, recognizing the 
services it render's to man, will not allow it to he killed on their property, but a great many are nevertheless annually destroyed, being often captured in the daytime in barns and other places which they are known to frequent; I have seen as many as fifteen in a bird-stuffer's shop in May, all of which had been recently received. The Barn Owl takes up its quarters about farm buildings and dwellings, because there, and in the neighbouring fields, it ean best find its usual food, which consists almost entirely of rats and mice; when it does take birds, they are generally Sparrows. Waterton, in his article on 'The Barn Owl and the benefits it confers on man,' which should be read by all interested in the country, remarks, 'If this useful bird caught its food by day instead of hunting' for it by night, mankind would have ocular demonstration of its utility in thinning the country of mice, and it would be protected and encouraged everywhere.... When it has young it will bring a mouse to the nest about every twelve or fifteen minutes.' MIy friend Mr. J. Whitaker has recorded an instance of its good offices in ridding dovecots of rats. (Birds of Nottinghamshire, pp. I2, I3.)

During the height of summer, when twilight lasts only a few hours, the Barn Owl is forced to prolong its foraging far into the hours of daylight, and I once saw one fly overhead as late as ten o'clock on a bright sunny morning.

The Barn Owl rears two, and sometimes three, broods in the season; the second lot of eggs being laid before the first brood are flown, nesting goes on continuously through the summer, and young birds are sometimes hatehed very late in the autumn; one under the Messrs. Matthews' observation was not fully fledged before the end of Norember.

In addition to its well-known screech, and the call-note ' keevak,' the Barn Owl also utters a hoot, and, notwithstanding all that has been written to the contrary, I am confident that this is the case. I have had ample opportunities of listening to the cries of this species and the Tamny Owl, 
often at the same time, or within a fer minutes of each other. The hoots are quite different and are easily distinguished, that of the present species wanting the first short sharp liŏo of the Tawny Owl, and also the subsequent long-drawn tremulous note, and is in fact a simple rather long 'hooooo', the pitch dropping gradually, and the note having something of a wailing tone in it. Mr. A. H. Macpherson, having on one occasion heard a hoot, saw a Barn Owl fly close past him; and he kindly informs me that the note of this species is nearly a semitone lower than that of the Brown Owl. More than once I have heard hoots followed by a screech proceeding from the same tree, from which a Barn Owl has subsequently flown. It should be stated that the Rev. A. Matthews, who also enjoyed excellent opportunities of observing Owls at Weston-on-the-Green, held a contrary opinion to that here expressed. (Cf. Zoologist, 1849 and I880.)

Examples of the Barn Owl in which the white in the plumage is unusually developed are not infrequently met with. In May, I 883, I examined one with the tail pure white with the exception of one or two small marks hardly perceptible; the primaries exhibited a good deal of the same, while that on the throat passed round each side of the neck, nearly meeting on the nape.

\section{THE GREAT GREY SHRIKE.}

Lanius excubitor.

The Great Grey Shrike, in one or other of its forms, is a winter visitor, but of very irregular occurrence.

The typieal form may be distinguished at all ages by the presence of two white spots on the closed wing (eaused by the white on the secondaries showing beyond the superineumbent (everts) from that known as Pallas' Shrike ( $L$. major), in which there is no white on the secondaries. The ranges of these two sub-species overlap in northern Scandinavia, whence 
probably most of the visitors to Britain emanate, and it is certain that although examples of the typical form have occurred on several occasions in Oxon, yet birds presenting characters intermediate between the two are more frequently met with. I have not yet seen an example of the true Pallas' Shrike obtained in the county, but a satisfactory examination in this respect of birds preserved in glass cases is impossible.

Grey Shrikes have been observed or procured during the last ten years on the following occasions :-

One shot at Banbury, 29th November, I880, was seen on the previous day, when it dropped a Water Shrew. Another procured in the same locality rather earlier in the year. One shot at Chorton near Islip in January, 1884 (G. Arnatt in Tit.). One seen by the canal near Bodicote, Ioth February, 1884. One shot at Tackley, near Woodstock, November, I884 (W. C. Darbey in lit.). One shot near Williamscote on the borders of the county, 26th December, 1884. One shot on the borders near Wardington, 26th February, 1885. Two seen by myself in the vicinity of the canal above Banbury, 7th April, 1885. One shot at Drayton near Dorehester, I 3 th November, I 888 (IV. Nenton, jun., in lit. $)^{1}$. Three of these, with another, one of two procured at Hook Norton some years ago, are in my brothers' and my own collection, and only one is of the typical form. Lord Lilford has an example shot at Garsington in I 853. All these specimens, it will be observed, were procured or observed during the period between November and spring, but the Messis. Matthews, while recording the occurrence of three specimens in their own neighbourhood, and of several more in other parts of the county in winter, mention one procured on the 5th August, I 810. This statement might

1 At Kingham, on the i 5 th January, I889, Mr. E. D. Lockwood saw a Grey Shrike fly up into a tree with a small bird or mouse in its claws. Here it proceeded to hammer its prey, accompanying each blow with a jerk of its long tail. This bird remained in the vicinity for some weeks, and was observed by Mr. Fowler, a month later, in the meadow below his house (W. W. F. in lit.). 
suggest an erroneous assumption of the bird breeding with us, but it has never been ascertained to do so in this country.

The only occasion upon which I have had an opportunity of observing the Grey Shrike in a wild state occurred, as mentioned above, on a colil wet day on the 7 th April, 1885 ; its habits and appearance on that occasion seemed similar to those of its more common congener to be next treated of. I extract the following from my note-book. 'From one of a line of pollard willows out darted a Grey Shrike, dipping in its flight, and rising into a tall forest tree a little further on. It was presently joined by a second bird, when both swooped down and flew together into some market-gardens on the other side of the canal, where they settled in a tall pear tree, one taking up its position on one of the outside branches. During the next ten minutes one or other of them several times darted out, and after taking a short flight among the orchard trees, returned to its post. After some time they flew out together, and, skimming low over the meadow, resorted again to the willows.' The broad ditches in the vicinity probably yielded a plentiful supply of food in the shape of water-shrews (the remains of which I have known to be taken from Shrikes' stomachs in one or two instances) and frogs. The flight of the Grey Shrike is undulating, being performed usually in jerks, but is swift and almost glancing at times, somewhat similar to that of the Red-backed Shrike, but more powerful. Wherever they went they were slightly mobloed by small birds, especially Chaffinches.'

\section{THE RED-BACKED SHRIKE.}

\section{Lanius collurio.}

Tre Red-baeked Shrike is an annual summer visitor, but cannot be considered as other than rather a rare bird except in the neighbourhood of Oxford and perhaps in the extreme south of the county; and even at Oxford the Rev. H. A. Macpherson remarked that it was far less common than nearer 
London, but that one or two pairs bred about Binsey and in the high hedges about Horspath. At Cuddesdon, however, Mr. H. Gale sees several pairs every summer. Mr. W. W. Fowler only notices one pair each year in the neighbourhood of Kingham, and a single bird brought to Mr. Warner in May, I 885, was the only instance in which he ever met with it about Standlake. In the north of the county I have personally only seen it on two occasions, and have heard of but few other instances of its occurrence during the last few years. From the extreme south of the county I have no information respecting this bird, but it used to be not uncommon some years ago on the Berkshire side of the Thames in the neighbourhood of Reading. Nevertheless the Red-backed Shrike is known to some in the county by its common name of Butcher-bird. This name it has carned by its curious habit of impaling or hanging its superfluous food upon thoms, forming a 'larder' to which it resorts at convenience. This hung food consists chiefly of large insects, and more rarely of young birds, shrews, etc. In the larder of a pair nesting at Great Bourton in 1883 I found only insects, consisting of two species of bumble-bees, the Dor-beetle (Geotrujes vernalis), and the large Ground Beetle; numerous 'castings' found under the perches usually affected by the birds consisted of remains of small insects, chiefly coleopterous. Mr. W. W. Forrler having observed a Red-backed Shrike at Kingham in July, ı 886, made a careful search for pellets, and found, among other things, two portions of the shrivelled skin of a Water Shrew, each forming a complete ring, hung securely upon thorns.

The Woodehat Shrike ( $L$. auriculatus) is included in the Iristory of Banlury list on the authority of Mr. Loftus with the remark 'not found now.' It is extremely doubtful if this species ever occurred in the county; so far from being more plentiful in England in former times it is only comparatively of late years that its claim to a place among the British avifauna has been fully allowed. 


\section{THE SPOTTED FLYCATCHER.}

Muscicapa grisola.

Tre Spotted Flycatcher is a common summer visitor, and a familiar garden bird. It usually arrives with us about the first or second week in May, and commences nesting operations almost at once. On one occasion, in I885, I have observed it as early as the 28th April. From observations made in a garden at Bodicote, where two or three pairs have nested regularly for many years, I am satisfied that Flycatchers rear always two, and in some rare cases even three, broods in a season. They leave us by the middle of September.

\section{THE PIED FLYCATCHER.}

Muscicapa atricapilla.

Tire Pied Flyeatcher is a passing visitor in spring on its way to its breeding haunts, but is of rare occurrence. The Messrs. Matthews record a male seen by one of them in Middleton Park on the 23 rd April, 1848 , and a pair in their collection shot near Oxford a few years before; also that it had been observed by Mr. Roundell near Fringford (Zoologist, 1. 2532); and the Rev. A. Matthers was informed by $\mathrm{Mr}$. Forrest, an Oxford bird-stuffer, that a pair once built at Headington near that city (in lit.). It was upon Mr. Matthews' authority that Mr. A. G. More (Ilis, I 865) included Oxford among the counties in which the Pied Flycatcher nested occasionally (in lit.); and these records, as the Editor kindly informs me, appear to have been the foundation for the statement in 'Yarrell' (vol. i. p. 23I) that the Pied Flycatcher had been recorded as having' occasionally bred in Oxon. A Pied Flycatcher was seen darting from and returning to the iron rail round a pond at Williamscote on the 28th April, I88+ (Field, 3rd May, 1884), and Mr. W. Warde Fowler saw a pair in a field studded with small trees close to the church at Kingham on the 24 th April, 1886 . In late 
spring, about the year I860, Mr. W. Wyatt of Banbury and a friend shot three Pied Flycatchers at Pinhill, between Banbury and Hanwell, but he did not have another specimen through his hands until 1888, when a remarkably fine adult male (the skin of which is in my possession) was sent to him

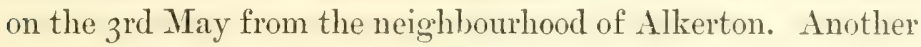
male had been shot over the Northamptonshire boundary the day before. On the 2gth April, I 888, Mr. Julius Sankey, of Oxford, saw a single bird in a lane at the corner of Marston Wood near the eity.

\section{THE GOLDEN ORIOLE.}

Oriolus galbula.

THE Golden Oriole is a rare summer visitor to England, and has been procured in Oxfordshire on three occasions. A specimen in the dress of the female, or immature male, was shot near Chipping Norton Junction station in May, I862 (R. F. Tomes in lit.), and a fine adult male at Bloxham Grove, in a field studded with hawthorn trees, in the spring of either I 869 or I 870 , most likely the latter, as in that year a number of these beautiful birds appeared in the south-west of England. Early in May, I880, two adult male Golden Orioles were shot in a wood near Great Tew, and brought to Mr. Wyatt of Banbury, from whom I purchased them a day or two after. The man who shot them said they were carrying grasses up into trees and hanging them orer the branches, a circumstance which suggests the probability that they were engaged in forming their curious nests, which are suspended under the forked boughs of trees; the hen birds were doubtless also present, but escaped notice on account of their more sombre plumage. One of these two males, which are now in my brothers' collections, is in peculiarly fine plumage, the golden yellow colour being remarkably deep and rich. 


\section{THE DIPPER.}

Cinclus aquaticus.

The Dipper is only an occasional visitor of casual occurrence, our county wanting the rushing boulder-strewn streams with rocky banks, which afford it a congenial home in the north and west of England. A Dipper was observed on the banks of the Cherwell near Weston-on-the-Green on the 6th May, 1850, by Mr. Willughby Beauchamp (Zoologist, pp. 2982-3). Mr. T. Beesley has a note of one which flew against the telegraph wires near Claydon on the 3 oth Mareh, I 874, and his annotated copy of the Mistory of Bantury list contains the entry 'North Newington, 28th June, I880.' Two were reported to the Rev. H. A. Macpherson as seen on the Isis at Sandford in October, I879, and a single one was seen by an Oriel friend of his, in May, I88I, on the Cherwell above Marston Ferry. A Dipper shot in the northern extremity of the county on the 2oth February, I886, is in Mr. F. C. Aplin's collection, and I have seen another which was procured in the winter, ahout that year, at Heythrop.

Instances of the Dipper nesting away from its usual haunts are extremely rare, but one such occurred at Claydon in May, I 876 . The nest, which is of the usual domed pattern, resembling in shape that of a Wren, with thick walls of moss, was placed close to the water's edge in the stump of one of the stunted thorn bushes which grow commonly along our streams. The hen bird was captured on the nest and the male was shot; these, with the nest and four eggs, are preserved at an inn in Banbury.

Since this account was written, Mr. I. J. Bartholomew has recorded in the Field (1888, vol. ii. p. 509) his observation of a pair of Dippers at a large pond near. Woodstock, on the 18 th September, I 888. 


\section{THE MISTLETOE-THRUSH.}

Turdus viscivorus.

Tre Mistletoe-Thrush is a resident, but is more numerous in early autumn, at which season small migratory flocks arrive which are often mistaken for early Fieldfares. A wild and unapproachable bird at most seasons, only tamed in winter by the sererest weather, it becomes bold and confiding in spring, building its nest in gardens and orchard trees close to dwellings. The sweet wild note of the Mistletoe-Thrush, heard on some mild January day succeeding a prolonged frost, has doubtless gladdened the heart of many a dweller in the county.

The local name for this bird is peculiar, and of considerable interest. It is called the 'Norman Gizer,' sometimes modified into Norman Thrush, and more commonly shortened into Norman or Gizer alone; and in North Oxfordshire I have never heard the name at the head of this article used by countrymen. I hardly think that 'Norman' has any connection with 'northern,' and there seems to be some reason for thinking that the name was conferred on the bird from a common belief that it came here with the Normans, who were very powerful and had several castles in Oxfordshire at an early date. There is good evidence to show that formerly this Thrush was not at all a common or widely-distributed bird in England, and its first appearance in this part of the country may possibly have been coincident with the Norman invasion. The second name, 'Gizer,' also supports this view. Mr. W. W. Fowler suggests that it may be derired from the French word for the mistletoe, gui, which in Norman-French would be guix. The Normans, recognizing it as a bird known to them, might call it the 'Guizer,' and the Linglish, connecting it with the arrival of their conquerors, and knowing no name of their own for it, would naturally term it the Norman Gizer or Gizer. 


\section{THE SONG-THRUSH.}

Turdus musicus.

TuE Song-Thrush is resident as a species, but migratory as to individuals; that is to say, it is probable that the birds which winter with us are not the same individuals which have bred or been hatched here in summer. A certain number always pass the winter here, but this depends to some extent upon the nature of the season, more remaining during a mild than in a severe winter, while in very hard weather they have sometimes almost entirely disappeared. This migration of winter birds is probably only internal, and does not extend beyond the sea. About the beginning of February they begin to return to us, and though some of our wintering Thrushes, under the influence of genial weather, will have sung occasionally from Christmas onwarks, it is about this time that in mild seasons every shrubberied garden, copse, and wooded hedgerow will resound, morning and evening, with the varied music of the Song-Thrush-a song which can be more nearly expressed in words than that of any other of our birds. The Song-Thrush has considerable powers of minicry: I once knew a caged bird which could imitate admirably the mewing of a cat-about the last sound one would imagine a bird would like to hear.

In September large numbers of migratory Song-Thrushes visit us, haunting at first the turnip, potato, and bean fields, and later on resorting to the hedgerows to feed on the ripening fruit. Many sportsmen must have been struck by the numbers of Thrushes they sometimes flushed when beating out a field in September; and later in the season, as you walk down the hedgerows, they fly out every few yards uttering their sharp 'tsic.' These migratory birds do not remain after November. 


\section{THE REDWING.}

Turdus iliacus.

The Redwing is a regular winter visitor, arriving from the first to the third week in October, and being seen with us until the end of March, and, rarely, until the begimning of April. Irregular in its numbers which visit us each year, the Redwing is always most abundant in autumn and again in spring, a portion at least of those which arrive here passing onwards to winter further south, and revisiting us again on their northern passage in early spring. Occasionally they will all disappear during the heart of winter, as for instance in that of $1878-9$, when between the middle of December and the I th February I failed to discover a single bird. But the question of their abundance or scarcity at midwinter does not appear to depend entirely upon the nature of the season, although in severe weather the Redwing, from its insectivorous habits, is always one of the first birds to succumb when the ground is covered with snow, or bound in the grip of frost.

Previous to its departure in spring the Redwing is sometimes heard to sing. The Rev. A. Matthews has related the fact of having himself heard it on several occasions in Oxfordshire (Zoologist, I 864), and published some further remarks on the subject in the volume for $1880(\mathrm{p} .382)$. In March, 1887 , and again in the same month in 1888 , I listened to the song of the Redwing in the vicinity of a spinney of oak-trees in this parish, which is always a favourite haunt of these birds in early spring. The song has been well described by $\mathrm{Mr}$. Howard Saunders as consisting' of 'several clear flute-like notes, which may be syllabled as trui, trui, trui, tritritri.' (Manual of British Birds, p. 6.)

\section{THE FIELDFARE.}

Tudus pilaris.

The Fieldfare is a regular winter visitor, arriving sometimes as early as the third week in October, but more commonly a 
little later, and being seen in large flocks all through March, and in smaller numbers often to the end of April; in 1880 I observed about a dozen Fieldfares as late as the gth of May. As a rule the Fieldfare is far more abundant in autumn and spring than at midwinter, retiring further south at the approach of severe weather; yet this rule is not without exceptions, and, as with the numbers which visit us in the first instance, its abundance or searcity at the latter season is most irregular and quite irrespective of the nature of the season. For instance, in the exceptionally mild weather in $1882 \mathrm{I}$ did not see one from the opening of the year until the latter part of March; and on the other hand, during very severe frost in January, I886, one of the largest flocks I ever remember to have met with was in the habit of resorting to Clattercote Reservoir, to drink at one or two unfrozen holes, the ice around being quite discoloured by them.

During the excessively severe weather in the first half of March, I886, Fieldfares suffered greatly, and many could be caught by the hand, too weak to fly. The supply of haws being almost exhausted, they had great difficulty in obtaining food, and might be seen greedily feeding on the half-rotten swedes in the sheep-pens. At such times great numbers are shot and exposed for sale by the game-dealers, but they soon become so thin as to be almost worthless, and in February, I 888, they were hawked about by men who asked only one shilling the dozen for them.

A curiously-coloured Fieldfare, the skin of which is now in my possession, was killed near Banbury on the 25th January, 1886. In this specimen, a female of the previous year, the head and the lower part of the back are strongly tinged with brown, while the usual grey of the upper tail-coverts is replaced by deep chestnut brown. The ground colour of the under tail-coverts is a warm buff, almost rust colour, and the flank feathers are of a somewhat deeper tint, with the usual dark markings. The golden buff of the throat and breast is warmer 
and more extensive than in typical specimens. Another peculiarity pointed out by Professor A. Newton, who kindly examined the skin, is that the fifth primary in the right wing has the inner web mottled with dull white towards the tip, showing an additional tendency to abnormality. Nevertheless I cannot regard it as a purely abnormal variety, in the ordinary sense of the expression, but rather as an instance of a peculiar phase of plumage occasionally, though rarely, assumed by the Fieldfare in a greater or less degree. The skin was submitted to several ornithologrists, but the only specimen at all approaching it in appearance of which I could hear was kindly lent to me by Mr. J. Backhouse, jun.; the peculiar warm brown colouring was, however, much less strongly developed in Mr. Backhouse's example.

\section{THE BLACKBIRD.}

Turdus merula.

'Tre Blackbird is a resident species, but, like so many of our birds, is also migratory to a certain extent. Towards the middle or close of September, and on through October, we receive considerable additions to the numbers of our Blackbirds. The corner of a field of standing beans sheltered by thick hedgerows is often found to be full of them, for the Blackbird loves concealment and is ever loth to fly far across the open; later in the season the hedges teem with numbers which resort to them to feed on the ripe berries. These migrants soon pass on, but leave always a good number to winter with us, far more remaining during that season than is the case with the Song-Thrush. The Blackbird is the earliest woodland bird to open song in the morning, and at that time seems to forget his shyness, as perched on the topmost twig of some tree or bush, he pours forth his mellow whistle-the mellowest song of all our birds, and heard to perfection on some still, warm, wet 'growing' day in May.

In the following pages $I$ shall make but little mention 
of the white, pied, or other abnormally coloured varieties of birds which have been procured in the county. The subject of abnormal variation is an extremely interesting one, but from a local point of view the mere enumeration of such varieties is quite valueless.

Blackbirds are peculiarly liable to variation of this kind, but a perfect albino of this species, which was caught near Shutford in August, I883, was such a beautiful bird as to be worthy of some notice. The plumage was snowy white and the feathers remarkably delicate; irides, feet, and legs pale pink. The bill was the only part showing normal colouring, and the yellow of this was curiously suffused with a pink tinge. I may add that albinisms (i. e. examples in which the irides, bill, and legs are pink or deficient in colour) are much more rarely met with than birds which merely exhibit variation in the plumage, while retaining the normal colours in the soft parts.

\section{THE RING OUZEL.}

Turdus torquatus.

Tue Ring-Ouzel is a passing visitor in spring and autumn. At those seasons, the Messrs. Matthews write, it may frequently be met with on the hills near Stokenchurch belonging to the Chiltern range (Zoologist, p. 254I). The Rev. Murray A. Mathew has seen it at Eynsham (in lit.), and Mr. Prior in the gorse at Milcombe (Banbury Guartian). In spring it generally appears about the end of April. A specimen was procured at Epwell on the 26th of that month in 1880 , and others at Williamscote and Banbury on the 24 th and 27 th in 1884. In 1886, however, a male was shot at Headington Hill near Oxford quite early in the month. In autumn it has been less often observed, but it probably occurs more frequently than is supposed, as young birds of the year at that season are only indistinctly mottled on the under parts with grey and light brown, the white gorget being wanting, and in that 
stage of plumage might easily be overlooked from their resemblance to Blackbirds. A young male in this dress, which came into my possession in the flesh, was shot at Hook Norton on the 22nd November, 1887 , which is a late date for it to remain with us. Others have been obtained in antumn in the neighbourhood of Banbury, on the I8th October, 1876 (C. M. Prior), and in 1878 .

\section{THE HEDGE SPARROW.}

Accentor modularis.

The Hedge Sparrow is a common and familiar resident, breeding early in the year in a great variety of exposed positions, so that its blue-green eggrs often fall a spoil to the birds'-nesting boys, by whom it is invariably known as the 'Billy.' It is a hardy little bird, and its cheery song may be heard on almost any fine day in winter.

\section{THE REDBREAST.}

Erithacus rubecula.

The Redbreast, or Robin, is resident as a species, but at the same time it is partially migratory, some of the birds which are bred here moving southward in autumn, their places being taken by others from further north. Speaking of this internal migration, Mr. W. W. Fowler writes, 'At Parsons' Pleasure I have seen the bushes literally alive with them in October and November, in a state of extreme liveliness and pugnacity.' (A Tear with the Birls, p. 6.) For all its readiness to avail itself of human assistance the Robin is a hardy bird; a familiar resident for the most part in the neighbourhood of dwellings, it often takes up its winter quarters in the fields, where, protected by its thick fluffy plumage, it braves out the most rigorous seasons, picking up a precarious sustinence among the thick dead herbage in overgrown hedge bottoms and the cormers of plantations. It would seem curious that the Robin does not increase more, since it enjoys a singular 
immunity from human persecution, were not the depredations of the cat remembered. Even the bat-fowling boys, into whose nets it not infrequently falls, always restore it to liberty - perhaps from a superstitious fear of bad lnek, perhaps from affection-but it is all the same to the Robin. A very wet cold summer following a hard winter prolonged into spring, such as was experienced in 1879 , seems to have a disastrous effect also upon the Robin's numbers. In that year I made a note in Angust that I had not seen a nest that season, and not a dozen birds all the year. Like most of our warblers the Robin likes a little ripe fruit to help him through his moult in late summer, and may often be caught in the act of bolting red currants whole.

Singing constantly all through the year (some early hatched individuals, through their moult, striking up even in the silent month of August), its song is very sweet but has a certain sadness, and, drowned among the swelling chorus of spring and early summer, it is oftenest heard and best appreciated in severe weather in the early part of the year, when snow lies deep on the ground, but cannot silence the Robin; or in those calm quict days we sometimes get when autumn first begins to make its presence felt, and the little gentle lay seems so thoroughly in harmony with the fading year. It was such a day that Keble had in his mind:-

'The morning mist is clear'd away,

Yet still the face of heaven is grey,

Nor yet th' autumnal breeze has stirr'd the grove;

Faded yet full, a paler green

Skirts soberly the tranquil scene,

The red-breast warbles round this leafy cove.'

\section{THE NIGHTINGALE.}

Daulias luscinia.

TuE Nightingale is a regular summer visitor, arriving from the beginning of April onwards, and has been heard singing as early as the 7 th of that month by the Rev. T. IT. Falcon. 
In some years, however, Nightingales arrive at the latter end of the month; one which flew against a window in Banbury, and was picked up dead, on the night of the $24^{\text {th }} \mathrm{April}$, I 886, was evidently on migration.

The distribution of the Nightingale in this county is by no means general, Mid-Oxon and the Thames district having it in greater plenty than other parts of the county. About Oxford it is numerous, and also in the neighbourhood of Weston-on-the-Green (Zoologist, p. 2534), and it apparently breeds commonly in suitable localities all along the Thames valley. The extensive woods at Nuneham Park, with their luxuriant undergrowth of hazel, and glades blue with wild hyacinth varied with pink lychnis and white satin flowers, resound in May with the song of many Nightingales. In the bare beech moods of the northern Chilterns it is, however, scarce (B. D'Oyly Aplin). About Kingham it is much less common than at Oxford, breeding only in a few known spots (W. W. Fowler). In the northern division it is rather scarce. Certain localities, where some five-and-twenty years ago it was to be heard commonly, have of late years been entirely deserted, its strange disappearance being remarked upon by many who in former years listened to it annually. During many year's' residence at Bodicote $I$ never heard it; neither have $I$ yet met with it in this parish. In the neighbourhood of Great Bourton, however, two or three pairs were to be found annually, and it is probably sporadically distributed over the district in an extremely irregular manner.

Seldom heard after midsummer day at the latest, it probably leaves us early in September; but the Messis. Natthews say that it sometimes remains unusually late in autumn, and they instance a freshly-killed female brought in by a cat on the Ioth November, I836. (Zoologist, p. 2534.)

The song of the Nightingale differs greatly from that of any of our other birds, and though many unobservant people, waking in the early hours of a May morning, and eatching 
the first few notes of a Blackbird or Thrush saluting the dawn, fall asleep again with the calm assurance that they have heard the Nightingale; yet the full, rich, clear, highpitched notes once heard by those who have an ear for birdmusic will never be forgotten or confused with those of even our sweetest warblers.

\section{THE REDSTART.}

Ruticilla phonicurus.

Trie Redstart is a common summer visitor, arriving about the second week in April and leaving in the latter part of September. Breeding freely in suitable spots all over the county, it frequents gardens and ornamental grounds to a large extent. It is perhaps the most beautiful, and certainly the most showy, of all our warblers. From its habit of perching in an exposed position, its sprightly actions, and the incessant and vociferous repetition of its alarm note when its nest is approached, it is a very conspicuous bird. Although now numerous it was much less plentiful a few years ago. The Redstart usually builds in a hole in a tree or wall, but I have known the nest placed in a crevice in the face of a stonepit, open to the sky, and in May, I888, I saw a nest of this species built in a thick honeysuckle trained on a trellis on the house at Nuneham.

In the spring of 1883 I examined a Redstart, shot near Banbury soon after the arrival of these birds, which was in almost exactly the same plumage as a male after it has completed its autumn moult. It is possibie that this bird may have been bred in the Redstart's winter quarters.

\section{THE BLACK REDSTART.}

Ruticilla titys.

THe Black Redstart is an occasional visitor, and, unlike the common species, should be looked for in winter. Lord Lilford has an adult male which was killed near Oxford a day or two 
before the 24th March, 1852 (Zoologist, p. 3476), and Mr. W. Warde Fowler (who is familiar with this species in the Alps) watched one, at a distance of a few yards, enjoying the sumshine on some walls and heaps of stones close to Kingham on the 6th November, 1884 . It appeared to be an old male (in lit.). On the 5th November, 1888, Mr. Forvler again met with the Black Redstart at Kingham, near the Chipping Norton Junction railway station. When first seen it was sitting on the top twig of a hedge, but afterwards flew to the signalman's cottage garden, where it was watehed for some time through the binoculars as it sat on a new stone wall bounding it. Mr. Fowler thinks it was a bird of the year. 'Head, neck, breast, and back were all brown, but suffused with black; and there was dusky white on the wing. It was quite tame' (in lit.). Unfortunately I just missed seeing the bird, having only left Mr. Fowler an hour before. Other instances of its occurrence have been reported, but are not satisfactory.

\section{THE STONECHAT.}

Saxicola mbicola.

THE Stonechat is a resident species, but is much less common in winter. From the fact that its summer haunts are then for the most part deserted, and that there are some parts of the county where it is never seen during the winter months, it has been much overlooked at that season, and is generally believed to be a summer visitor only. As a breeding species the Stonechat is very local. Rather high ground, more or less covered with gorse or juniper bushes, seems essential to it in the nesting season, and in summer it is rarely found away from such spots. It breeds on Wigginton and Hanwell Heaths, on Tyne Hill, and on the top of Shotover Hill. In the first-named locality it is less numerous now than a fer years since, consequent upon the heath land being gradually brought into cultivation, or converted into rough pasture. 
In 1886 a pair nested on the steep bank by the side of the road between Banbury and Southam, where it rises at Hardwick Hill, but such occurrences are rare. It breeds numerously on the Chilterns, which appear to be its true home in the county. Here high up on the breezy hillsides, covered with short slippery turf and dotted with stunted juniper bushes and lumps of white chalk glistening in the sumlight, as you listen to the monotonous song of the Yellow Hammers and the twittering of the Linnets as they fly backwards and forwards from bush to bush, you cannot fail to notice the handsome male Stonechat as he sits in a conspicuous position on the topmost twig of some low bush flirting his tail and uttering his sharp chut, chut, his clear-cut black head, white collar, and rufous-tinted breast contrasting in a most pleasing manner with the peculiar dull green of the surroundings. In winter the birds which remain with us come down to lower grounds, often frequenting meadows, and sometimes ploughed fields, and they are then more generally diffused, being naturally more common in the low-lying country about the Isis.

\section{THE WHINCHAT.}

Saxicola rubetra.

THE Whinchat is a regular summer visitor in varying numbers, and is very common in some seasons. Found always on Wigginton Heath and similar situations, it usually prefers a lower elevation than the Stonechat: thus it is found on the lower part of Shotover Hill, and along the foot of the Chiltern range. It is, however, pretty generally diffused irrespectively of any particular kind of country. It is found on the higher com lands and in low-lying meadows; but it seems partial to the works of man, being very fond of railway banks and often taking up its quarters on the hedge bank by roadsides and footpaths, and along the Oxford and Coventry Canal. But the Whinchat never looks prettier than when sitting, as 
it often does, on the broad white flower panicle of some umbelliferous plant in the midst of a sea of meadow grass, swaying in the wind.

\section{THE WHEATEAR.}

Saxicola onanthe.

Tre Wheatear is a passing visitor at the periods of migration, occasionally remaining to breed. In spring it arrives from the end of March, appearing on the arable fields, and is seen until the end of April, the same individuals not remaining long. The autumn passage commences at the end of August or early in September, and Wheatears are occasionally seen in the early part of October; as late as the $3^{\text {th }}$ of that month in I 880 one was shot while sitting on the ridge of a barn roof at Bodicote by the Rev. B. D'Oyly Aplin. During their stay with us they haunt the ploughed fields, bare upland grassfields, and downs, as well as the rough meadows, and are often seen on the railway banks in small parties of up to a score in number. At such times they have been noticed about Weston-on-the-Green, Kingham, Oxford, Chinnor, and Ewelme Common, when they are sometimes in numbers ( $\mathrm{W}$. Newton, jun. in lit.). Also commonly in parts of the north of the county, where they are known to agriculturists, and were well described to me as arriving about the time of barley sowing upon the fallows, sitting out on the clods of earth, and showing white on their backs when they flew. The Rev. H. A. Macpherson thought the Wheatear bred in some fields about Marston Ferry, near Oxford, which they frequented in May and June, I878, I879, and I880. The Messrs. Matthews also say that it did so occasionally in their neighbourhood (Zoologist, p. 254 I). An egg taken near Barford in I 885 was shown to me, and in the early part of July, 1888 , I saw near Nether Worton a Wheatear which I had no doubt had a nest in a heap of stones by the side of the field road between that place and Hempton. I have also met with individuals 
in May and early in August, which doubtless nested with us. Examples procured in autumn have, as far as I know, always been of the larger race; in spring small birds occur, but one which I observed on the 27 th March, I88I, at Adderbury, sang from the topmost twig of a tall hedge, a characteristic, according to some writers, of the larger race.

\section{THE REED WARBLER.}

Acrocephalus streperus.

TuE Reed Warbler is a regular summer visitor, but of local distribution. The Messrs. Matthews say that it was met with in one small covert near Weston-on-the-Green (Zool. p. 2533); and in various localities along the Thames valley it is always to be found. A few bred above Godstow, and perhaps more below Sandford (H. A. Macpherson), and on the reed- and willow-clothed banks of the upper Isis in the neighbourhood of Bampton I have found Reed Warblers common and even numerous. In the Parks at Oxford it is always to be found on the banks of the Cherwell at the spot known to Oxonians as 'Parsons' Pleasure,' where, in company with Mr. Fowler, who has paid considerable attention to this species, I have seen it in fair numbers. In the Botanic Garden and in Christ Church Meadow also I have listened to its song. The Rev. F. O. Morris was informed by Mr. J. Dalton that the Reed Warbler bred in Worcester College Gardens, and other localities about Oxford might be enumerated. Mr. H. Gale informs me that it used to breed numerously in a tributary of the Thame, near Cuddesdon, but has decreased of late years. This falling off in their numbers Mr. Gale is inclined to attribute to the fact that Cuckoos' eggrs are so often deposited in the Reed Warblers' nests, a state of things of course resulting in the birds so visited rearing up the young parasite instead of four or five of their own species. So commonly was the Reed Warbler's nest selected by the Cuckoo, that upon discovering a nest of the former it was more usual than not to 
find a Cuckoo's egg in it. In the north of the county it is rare, but $I$ have observed it in the large bed of rushes at the upper end of Clattercote Reservoir, and in an osier-bed at the mouth of the Swere.

Found usually only where a thick growth of reeds and rushes affords it congenial shelter, it occasionally wanders from its usual haunts, and a bird 'sang away all the Summer Term of 1884 in the bushes behind the Museum, nearly half a mile from the river, and probably built a nest among the lilac bushes which there abound.' (A Iear with the Birls, p. 34.) The nest of this species is a most beautiful basket-like structure, suspended between the upright stems of three or more reeds or twigs, and formed mainly of the upper portions of reeds or of long grasses wound round so as to include the supports in the walls of the nest; it is very deep in proportion to its width.

Being a shy bird, the Reed Warbler is more often heard than seen. Its song resembles to some extent that of the Sedge Warbler, from which, however, it is easily distinguished. Delivered in a more leisurely fashion, and in a lower tone, it has greater sweetness and more melody, and wants the harsh chattering notes of the Sedge-bird; the opening notes of the song churra churra churra are quite characteristic.

\section{THE MARSH WARBLER.}

Acrocephalus palustris.

TnE Marsh Warbler, which has of late years been proved to be a rare summer migrant to some parts of England, has visited Oxfordshire in one year at least, a nest and eggs presented to the British Museum by Mr. B. M. Davies, of Broughton Grange, having been taken near that place in $\mathrm{I} 886$. In reply to my enquiries $\mathrm{Mr}$. Davies informs me that the nest was found in a withy bed, 'fastened in what I believe is the usual manner between some reeds.' He adds, 'I am sorry I cannot give you the date, but I have little doubt that it was 
in the month of June' (in lit.). In appearance this species is very similar to the Reed Warbler, but its song is said to be more melodious, and its eggs are described as having a whiter ground colour.

\section{THE SEDGE WARBLER.}

Acrocephalus schonobcenus.

The Sedge Warbler is a regular and abundant summer visitor, breeding commonly on the banks of all our streams where any cover is to be found, and frequently along hedgerows in the meadows and low grounds, a preference being generally, but not always, shown to those furnished with a wet ditch. A veritable mocking-bird, its hurried chattering song, made up of a mixture of its own rather harsh notes with those of numerous other birds, is one of the commonest sounds in our valleys in early summer, the footsteps of the passer-by rarely failing to awaken it even at midnight. The Sedge W arbler arrives about the middle or end of April, and leaves again in September; but in I 886 one was seen by Mr. A. H. Macpherson near the river above Oxford in cold weather as late as the 26th October.

\section{THE GRASSHOPPER WARBLER.}

Acrocephalus novius.

The Grasshopper Warbler is a regular, but far from abundant, summer visitor of very local distribution, breeding regularly in certain localities. The Messrs. Matthews found it by no means rare about Weston-on-the-Green, and give a figure of the male, female, and nest in their Account of the Birds of Oxfordshire, the male being represented in an attitude which they had often seen it assume when running up a twig in the act of singing. (Zoologist, I 849, p. 2425.) The male, as the Rev. A. Matthews informs me, was drawn from life, and the nest on the ground was figured in the situation in which he found it. In the neighbourhood of Oxford the Grasshopper Warbler is rare, but the Rev. Murray A. Mathew 
has in his collection a elutch of eggs taken at Water Eaton about I857 (in lit.), and I have heard it at Wootton, near Woodstock. In the Chilterns it has been observed on one occasion among the ling and bracken by the Rev. B. D'O. Aplin. On Wigginton Heath, where I have often heard it singing among the broom, my brother and I procured a young' one in 1880 , and three nests were discovered there in 1874 (C. M. Prior). On Hanwell Heath I observed it in the years $188_{3}$, 84,85 , and 86. From this spot it strays into the meadows below, apparently nesting in the hay-grass. Some pairs seem to breed casually in other localities in the north of the county, and $I$ have heard its song at Bloxham and Cropredy. Mr. W. Warde Fowler has observed it on the edge of Bruern Wood, near Kingham, a charming account of its habits being given in $A$ Year with the Birds.

The Grasshopper Warbler is one of the shyest of birds, rarely leaving the thick cover during the day time, but creeping about among the furze or other bushes in a mouselike way. Its curious song, which has been likened by some to the chirrup emitted by the Grasshopper, but from which it may at once be distinguished, is delivered in a continuous trill, producing a sound somewhat similar to that given out when the line is drawn rapidly off a fisherman's brass reel. Except in the early morning it is seldom heard before sunset, and for some hours after in early summer the bird sings almost incessantly, continuing even at midnight, the 'reeling' song being heard at a considerable distance in a still summer night. After dusk I have crept within a few yards of the bird in thick furze and timed the spells of song to last nearly six minutes, with only almost imperceptible breaks; at a little distance the trills appeared continuous. During the delivery of its trill the bird's beak is opened to its widest stretch, the mandibles remaining motionless. The rentriloquism in the song of the Grasshopper Warbler, often remarked upon, appears to be due to the bird turning its haad slowly round 
from side to side when singing, and to the varied pitch at which the song is delivered.

\section{THE DARTFORD WARBLER.}

Melizophitus undatus.

The Dartford Warbler is a scarce and local resident in England, being chiefly confined to the heaths and commons of the southern counties. In Oxfordshire it has been observed on two occasions at least, and it is probably a scarce resident in the county. The Messis. Matthews write, 'In June, I 834 , a pair of these birds were killed near Stow Wood, in the parish of Beckley, in this county, by Mr. Burney, of Exeter College; on the same occasion he observed several other specimens, and also found a nest with eggs belonging to this species....... Although we have repeatedly searched the locality in which they were seen by Mr. Burney, we have not hitherto been successful in finding any.' (Zoologist, 1. 2597.) 'In June, I878 or 79,' writes the Rev. H. A. Macpherson, 'I found, after a very long search, and much expenditure of quiet watching, a nest on the side of Shotover nearest IIorspath. I saw at least one bird well.' (MS.) Mr. J. R. Earle and I unsuccessfully searched this locality on the I th June, 1883 , but a few days after Mr. Earle received an egg taken there by a boy which appeared to belong to this species.

From the difficulty of detecting such a small bird in the dense masses of furze which form its usual haunt, it may easily be overlooked, and the Dartford Warbler may yet be found to inhabit this county in small numbers. Numerous it probably never was, or will be, the severity of Oxfordshire winters being unfavourable to the increase of such a delicate non-migratory bird in the open situations which it affects.

\section{THE GREATER WHITETHROAT.}

Sylvia rufa.

Tre Whitethroat is a regular and abundant summer visitor, arriving about the second or third week in April and re- 
maining until September. A common wayside bird, the 'Nettlecreeper' is rather less shy than its congeners, and may generally be seen creeping in and out of the hedge, or fluttering about the top, uttering its rather harsh chattering song, and often mounting in the air to deliver it on the wing.

\section{THE LESSER WHITETHROAT.}

\section{Sylvia curruca.}

The Lesser Whitethroat is a regular summer visitor, generally distributed, and locally abundant, arriving about the end of April. It is a very shy bird, and a difficult one to observe, only occasionally leaving the big hedgerows, which are its chosen resort, to flit up among the branches of some spreading oak or other leafy tree. Up and down the hedgerows you may follow the Lesser Whitethroat for hours as it creeps among the twigs in the very middle of the hedge, pausing every now and then to utter its curious song, often within a few feet of the observer. The song consists of a preliminary subdued warble, followed by a succession of highpitched metallic notes all in the same pitch. The Lesser Whitethroat continues in song until late in summer, and during a sultry evening in July it seems peculiarly happy, the song then being often incessant.

\section{THE GARDEN WARBLER.}

Sylvia salicaria.

The Garden Warbler is a fairly numerous and generally distributed summer visitor, seldom arriving before quite the end of April or the beginning of May, when the hedges are usually in full leaf. Then it generally makes its presence known by its sweet rich warbling song, for it is a very shy bird, seldom in the breeding season leaving its favourite haunts-thick hedgerows with plenty of bottom growth and tangled brambles, and the edges of thick woods, spinneys, and extensive shrubberies. In late summer it comes with its congeners to the kitchen-gardens for fruit. 


\section{THE BLACKCAP.}

Sylvia atricapilla.

THe Blackcap is a common summer visitor, arriving in April and remaining well on into September. It is a hardy bird; I have heard it singing actually during a snowstorm on a bitterly cold morning in early May, and the Rev. A. Matthews has recorded the fact of a male having been seen, apparently in good health, near Weston-on-the-Green on the Ist December, 1850, the weather then being very severe for the season.

The Blackeap is fond of breeding in gardens, where there is shelter suitable to its somewhat retiring habits. At the end of summer numbers come to fruit gardens to partake of the remains of the currants and raspberries; for it is one of the fruit-eating warblers, and though feeding its young, and subsisting itself, on insects during the summer, it will on its arrival in spring, when such food is scarce, eat ripe ivy berries.

The Blackeap is one of our finest song-birds, surpassed by none save the Nightingale, and in one characteristic its song is perhaps unrivalled. No one who has listened to its 'full, sweet, deep, loud, and wild pipe,' as White of Selborne most aptly describes the song, should grudge the Blackcap his reward of wasting fruit.

\section{THE WOOD-WREN.}

\section{Phylloscopus sibilatrix.}

The Wood-Wren, or - Warbler, is a summer visitor, but of extremely local distribution. The Messrs. Matthews record that a few specimens have been killed near Oxford, but they only once met with it in the neighbourhood of Weston-on-the Green. Mr. J. R. Earle has taken the nest of this species in one or two instances near Oxford. In the north of the county I have never heard its song, although in the oak woods on the 
slope of Edge Hill, a few miles over the Warwickshire borders, a pair or two may always be found. On the 19th May, I880, however, I observed a pair at Bloxham Grove. In Churchill Heath Wood, near Kingham, Mr. W. Warde Fowler observed it in May, I888. Mr. Warner, who is acquainted with its habits and appearance in Berkshire, has never met with it in the neighbourhood of Standlake. The only locality in Oxfordshire frequented by the Wood Wren in any numbers appear: to be the extensive woods at Nuneham Park, where I found a great many pairs in May, $\mathrm{x} 888$, and in company with Mr. R. S. Batson found a nest containing seven eggs in the Lock Wood on the 27 th of that month.

The habits of these delicate little birds form a most interesting study in field ornithology. I first became acquainted with them in some of the great woods of Sherwood Forest, under the able tutorage of my friend Mr. J. Whitaker, who has paid great attention to the natural history of this species, and who, I believe, first noticed the fact that the nest lining consisted of dead grass and not of hair. This lining serves to distinguish the nest of this bird from those of the Chiffchaff and Willow-Wren, both of which invariably line theirs with feathers.

The song of the Wood-Wren is very peculiar and distinctive, and can be heard at a considerable distance, so that if a wood is inhabited by a pair of these birds no one acquainted with their notes could fail to detect their presence on searching for them in early summer.

\section{THE WILLOW-WREN.}

Phylloscopus trochilus.

The Willow-Wren, or -Warbler, is a regular and abundant summer visitor, and in some seasons perhaps our commonest warbler. 'In Oxford alone there must have been two or threc' hundred pairs in the spring of 1885 .' (A Iear with the Birls, 
p. 25.) It arrives about the second week in April, and its silvery song is one of the commonest sounds on sunny days in springin the vicinity of sheltered spinneys, osier-beds, and big hedgerows; again in the latter part of August it is heard more sparingly. Previous to their departure in autumn, especially in the hazy September mornings, Willow-Wrens often swarm in kitchen gardens, where they do considerable good in ridding the plants and bushes of aphides and other insects.

\section{THE CHIFFCHAFF,}

\section{Phylloscopus collybita.}

The Chiffchaff is a regular and common summer migrant, but is not nearly so plentiful as the Willow-Wren. It is one of the earliest to arrive of our summer migrants. I have observed it as early as the 15 th March, and it probably always reaches us during that month; but as it generally first makes its presence known by its song, and in cold springs is silent on its first arrival except on very sunny days, it is often overlooked until April. The Chiffchaff often remains here until October, its autumn song being heard in fine seasons through September and up to the middle of the former month. An individual remained with us during the whole of the mild winter of $\mathrm{I} 88 \mathrm{I}-2$. It was heard on several occasions by $\mathrm{Mr}$. F. C. Aplin in his garden at Bodicote in December, more particularly towards the end of the month, and he obtained a

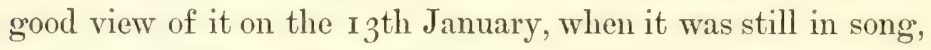
and frequently also later in the month. In the same garden, which is well supplied with evergreens and coniferous trees, he again observed a Chiffchaff in song on the 26th and 27th February, I 887 , two bright and sumny days. The season had been very severe, yet it is pretty certain that this individual was not a migrant, but had braved the frosts and snow of winter. 


\section{THE GOLDEN-CRESTED WREN.}

Regulus cristatus.

The Golden-crested Wren is a resident species, breeding regularly, but not commonly except in certain spots, in fir woods and spinneys, also in gardens, a preference being given to those which abound in conifers and yew-trees, in which it builds its wonderfully constructed nest suspended beneath the outer branchlets. In the beautifully planted grounds of Nuneham, where I have seen the nest, it breeds regularly and plentifully (E. W. Harcourt), as many as seven nests having been discovered in one year. There it usually builds in yewtrees, but one nest was found in a box-bush.

In winter, when the Gold-crest joins together in little bands, it is probable that we are visited by migratory individuals. A dozen were observed together in the larches on Chinnor Hill on the 9th February, I880, and I have several times seen them in little flocks. In the early part of December, 1883 , Golden-crested Wrens were unusually abundant; most of them were doubtless immigrants from a distance, one having flown through a window in Banbury, and several other's being captured about the same time.

\section{THE FIRE-CRESTED WREN.}

Regulus ignicapillus.

The Fire-crested Wren is an occasional visitor of very rare occurrence. An adult male, now in Mr. F. C. Aplin's collection, was killed near Banbury in December, I88I; another was seen by Mr. A. B. R. Battye twisting about in a yew-tree in the Botanic Garden, Oxford, on the 16th February, I883. In a case of locally common birds, set up some years ago by a working man in Banbury, I detected a male Fire-crest. While unable to obtain any precise information as to where they were killed, I have little doubt but that they were all procured in the immediate neighbourhood. 


\section{THE WREN.}

Troglodiytes parvulus.

THE Wren is a common resident, and, as far as I am awre, not here at all affected by migration. Always brisk and lively, even in the hardest frosts and most Siberian seasons, it seems to defy winter, and, among birds, is the personification of self-reliance and independence. It needs but a few gleams of sunshine and the semblance of a less rigorous condition of things to bring forth its song, loud, rapid, cheery, and sprightly, typical of the bird itself; but one cannot but wonder where the sound comes from in so small a bird.

\section{THE TREE-CREEPER.}

Certhia familiaris.

Tire Tree-creeper is a common but not numerous resident. From its quiet and unobtrusive habits it is but little observed when the trees are in full foliage, but in winter and early spring it is often to be seen creeping about the trunks and larger branches especially of orchard trees and pollard willows, to which it is very partial.

\section{THE NUTHATCH.}

Sitte cresice.

Tire Nuthatch is a resident in some numbers, but somewhat local in its distribution, especially in the breeding season, when it chiefly frequents wooded parks, ornamental grounds, and other situations which afford large timber. In such localities in the parks at Broughton, Wroxton, Great Tew, Wickham, Sarsden, Nuneham, and Blenheim, and at Bloxham Grove, the Nuthatch is numerous, and also abont many villages where old elms are found, such as Kingham, and Bodicote, where it is a frequent visitor to my brother's garden. A cedar of Lebanon there is a favourite feeding spot, the erevices in the bark being stuck full of the shells and husks of various large 
seeds and oats, on which they feed in winter. The Nuthatch also breeds in Christ Church Meadow, and in the gardens of St. John's College, Oxford. A suitable hole, when found, is resorted to year after year. A clutch of eggs was taken in May, $\mathbf{1} 886$, from a hole in a tall elm, into which $I$ had seen the old birds carrying materials, from which I had eggs more than a dozen years previously. I have known the Nuthatch dispossessed of its chosen breeding-hole by Starlings. In autumn and winter it wanders from its summer haunts for food, entering gardens, and being often seen feeding on the roofs of thatched buildings and on the ground, but it is seldom found far from trees. The Rev. H. A. Macpherson writes, 'In October, 1877 , an example flew into the house of Bryant the bird-catcher at New Hinksey, through a space of six inches; not only was it curious that it should select a fowler's house, but there were no trees near, and the house was one of a row in a double street' (MS. notes).

\section{THE GREAT TITMOUSE。}

Parus major.

THE Great Titmouse is a common resident. Its ever welcome spring note falls pleasingly on the ear, as one of the earliest sounds of the opening year, in the first mild days of January.

\section{THE BLUE TITMOUSE.}

Parus comileus.

Tri Blue Titmouse is resident, and the most abundant of the genus.

\section{THE COAL TITMOUSE.}

\section{Pamis ater.}

Tre Coal Titmouse is resident and tolerably abundant. In common with the species next to be treated of it affects a vegetable diet to a considerable extent, and is especially fond of the seeds of the sunflower. 


\section{THE MARSH TITMOUSE.}

Parus palustris.

TIE Marsh Titmouse is a resident and tolerably abundant, by no means confined to low-lying ground (as its name would imply) but found equally in more elevated situations. In winter this and the three preceding species join together, often in considerable bands, and haunt the beech woods and spruce and larch plantations.

\section{THE LONG-TAILED TITMOUSE.}

Acredula caudata.

The Long-tailed Titmouse is a resident, and although by no means numerous, is far from an uncommon bird. The large oval-shaped nest of this species, so conspicuous in late springs on account of the retarded foliage of the hedges, is eagerly sought for by the birds'-nesting boys, who always consider the 'Bumbarrel' or 'Bottle Tit's' nest as a great prize. In winter little family parties may be seen about the tall hedges, plantations, and rows of trees, carefully searching every branch and twig for their insect food, and following one another from bush to bush until they come to the hedge end, or to a break in the trees, when they take wing one after the other, each uttering its soft twittering chirp. When thus feeding they are very tame and often come within a few feet of the observer. So they continue the livelong day, and gather together at evening to roost in the tall thorn hedges, where the bat-fowlers find them huddled together in a ball-like cluster. At that season it is possible that we may receive additions to our numbers of this species, for on the roth December, I 878 , I counted fifty in a flock in the rookery elms at Bodicote.

\section{THE BEARDED TITMOUSE.}

Panurus biarmicus.

The Bearded Titmouse, or Bearded Reedling as it is more appropriately called, its relationship to the Titmice being very 
remote, formerly bred, according to Yarrell, in most of the south-east and eastern counties of England, and was probably at that time an inhabitant of, or a constant visitor to, the reed beds along the Thames and its adjacent tributaries in Oxfordshire. Dr. Lamb, about the year I8I4, wrote that it was frequent on the banks of the Kennet between Reading and Newbury, undonbtedly breeding about the latter place (Ornithologia Bercheria), and in 1840 it was included in the History of Banbury list on the authority of Mr. Loftus. But in I 849 the Messrs. Matthews mention only one specimen (on the authority of Mr. Roundell), which was shot some years before near Oxford, and preserved by $\mathrm{Mr}$. Wheeler of that place (Zoologist, p. 2597), showing that by that time it had become undoubtedly rare. The statement in the last edition of 'Yarrell' that the Bearded Reedling used to be found up the valley of the Thames as far as Oxford (vol. i. p. 520) was, as the Editor kindly informs me, founded on the above note of the Messrs. Matthews. As a wanderer it has occurred in Oxon so recently as 1883 , on the 22nd of February, in which year a Bearded Reedling was seen clinging to a branch just over the ditch which separates Christ Church Meadow from the inner gravel walk by the barges at Oxford. The bird was seen by a perfectly competent and accurate observer, then a member of Oriel College, who has communicated the particulars to me, but who prefers to remain anonymous.

\section{THE WAXWING.}

Ampelis garrulus.

The Waxwing, sometimes called the Bohemian Waxwing or Waxen Chatterer, is a rare and occasional winter visitor. The Messrs. Matthews state that several had been killed in the neighbourhood of Weston-on-the-Green, one in their collection being shot in Kirtlington Park (Zoologist, p. 2597). This last, as the Rev. A. Matthews recently informed me, was shot about the year 1830 . During the great immigration of this 
species in the winter of $1849-50$ only one specimen, according to the Rev. A. Matthews, was killed in Oxfordshire (Zoologist, p. 2799). An example shot many years ago in an orchard at Standlake is now preserved in a house in that place (Warner IISS.), and another was shot close to Banbury about twenty years ago (W. Wyatt), probably in I 866-67, in which winter there was a notable immigration of Waxwings into England. On the $13^{\text {th }}$ of February, 1886 , one was watehed for half an hour, while frequenting some thorn bushes in the grounds of a house on the outskirts of Banbury, by Mr. W. Wyatt, who is acquainted with the bird from having preserved specimens of it, and who communicated the fact to me two days later.

\section{THE PIED WAGTAIL.}

Motacilla lugubris.

Tпе Pied, or Water, Wagtail is resident as a species, but by far the larger proportion of individuals are migratory. A few always pass the winter with us, remaining even during the most severe seasons. At that time they haunt the pens where sheep are folded on the turnips, the straw yards where cattle are wintered, and, occasionally, the borders of streams so long as these remain unfrozen; in hard frosts they may often be seen running about the village streets, or fluttering up under the eaves of the cottages in search of any insects harboured there. 'Towards the latter part of February, if the weather is open, we first notice some movement among the Wagtails, and their clear ringing cry often draws attention to birds passing high overhead, singly for the most part, but often following closely one upon another. By the third week in March the migration is in full swing, and little parties of Wagtails, the males in beautiful fresh spring dress, haunt the fields where spring ploughing is in progress, their bright black and white plumage contrasting pleasingly with the deep red of our rich arable land as they run nimbly over the newly-turned furrowslices, and their sprightly actions and sharp lively notes, 
together with the rather Pipit-like song of the males, adding a charm to many a bright morning already teeming with signs of the opening year. Along the banks of the streams too, where these present suitable shelving under-banks of mud, numbers may sometimes be seen. But they are nearly all gradually passing on, and although for the short time the migration lasts their places may be taken by others, yet where you have seen dozens one day you may not see a bird the next. In April our breeding birds have settled down, and build their nests in a variety of situations, often in close proximity to human dwellings. The young, after they have left the nest, keep with the parent birds in family parties until the latter part of September draws them together in larger bands in riew of migration. Then again in the fine quiet days of early October, as in spring, we hear their cries as they fly overhead, little parties haunt the autumn ploughings, and our home-bred birds gather together to roost in some favoured spot in an osier-bed by the water side. Here at sundown the birds come flying in and either pitch directly into the osiers, or perch temporarily in some taller willow near at hand, the call-notes of the late arrivals sounding from afar as they approach the roost. I have counted as many as seventy fly in in a very short time. The roost is occupied for a week or two, and then by about the third week in October those that intend to winter south have chiefly taken their departure, and only our few winter residents remain.

Young birds on leaving the nest have the forehead, throat, and breast tinged with buff. The individual peculiarity exhibited by some young moulted birds in their first autumn, which have the forehead and cheeks suffused with pale but bright gamboge yellow, has come under my notice in Oxon on one occasion, viz. in October, 1886 , when I procured an example from a little flock at Great Bourton; another bird shot at the same time had not a trace of the yellow colouring, although otherwise in precisely the same stage of plumage. 


\section{THE WHITE WAGTAIL。}

\section{Motacilla alba.}

The White Wagtail, which on the continent takes the place of our Pied Wagtail, is a searce summer visitor to England, and has been detected in Oxfordshire on three occasions. On the I 7 th May, I884, I watehed through a strong field glass a White Wagtail, apparently a male, in a grass field at Great Bourton, and on the 27th September in the following year clearly identified two examples among a party of some nineteen black and white Wagtails, in various stages of plumage, in a field at Clattercote Reservoir. Mr. A. H. Macpherson saw a White Wagtail on the river bank above Oxford on the $4^{\text {th }}$ May, I886. In breeding plumage the adult White and Pied Wagtails may be distinguished by the colour of the back, which is of a clear pearl grey in the former, and either black (male) or sooty grey mottled with black (female) in the latter.

\section{THE GREY WAGTAIL.}

Motacilla sulphurea.

Tue Grey Wagtail is for the most part a winter visitor, instances of its breeding in this county, or being seen in summer, being rare. It arrives in autumn at the end of September or the beginning of October, remaining during the winter, and is usually observed singly or in pairs, but occasionally several may be seen together. The generally sluggish nature of our streams makes the Grey Wagtail a more local species with us than it would otherwise be, for its love of rushing water takes it to weirs, lashers, and the neighbourhood of water-mills, and thus certain spots are found to be invariably tenanted by them, and if there is a Grey Wagtail in the district you may be pretty sure to know where to find it. The author of $A$ Tear with the Birls gives as a frontispiece to his volume a drawing of the Weir on the Cherwell at Oxford, 
'A winter haunt of the Grey Wagtail,' and truly remarks' $\mathrm{He}$ is content with sluggish water if he can find none that is rapid; but the sound of falling water is as surely grateful to his ear as the tiny crustaceans he feeds on are to his palate' (p. II). At the periods of migration it is more generally diffused. Soon after the beginning of March the Grey Wagtail leaves us, and the instances in which it has been seen in late spring or summer are easily enumerated. One which had assumed the black throat of summer was killed at Weston-on-the-Green in the spring of I 846 (Zoologist, 2.536). In the summer of 1875 , Mr. C. M. Prior repeatedly saw a pair in an osier-bed on the banks of the Swere in the parish of South Newington. They frequently carried food in their beaks and were much agitated when he came close, but he was unable to discover the nest (Zoologist, I 879, p. I79). The Swere is a rather rapid stream in places. A pair seem to have remained during the summer of 1884 in the stream at Kingham, where they were seen in mid July, and possibly nested somewhere about the mill flood-gates (W. W. Fowler in lit.). On the I I th April, 1885, I saw a pair at a spring in a railway cutting near Adderbury, and Mr. A. H. Macpherson saw a single bird on the banks of the Cherwell near Islip on the 26th June, I 886. Writing to me on the is th August, I 884, Mr. Fowler reported that they had a small visitation of Grey Wagtails haunting the Kingham brook; these must have been unusually early migrants, and came probably from the Cotswold streams.

\section{THE YELLOW WAGTAIL.}

Motacilla raii.

RAY's, or the Yellow, Wagtail is a common summer visitor, arriving about the second week in April and leaving before the end of September. Showing less preference for the vicinity of water than do its congeners, this species is often locally known as the Land Wagtail, and though often to be found in the 
lower grounds, the greater number breed in the dry corn-fields. A little party of these birds, with their brilliant yellow colouring, on their arrival in spring, whether on the red-brown ploughings, or the fresh green pastures, is a pretty sight. Occasionally Yellow Wagtails arrive in very large numbers. Mr. W. W. Fowler wrote to me of an assemblage seen in Port Meadow on the 26th April, 1887, 'At every step they flew up from under the bank, and as I looked ahead with the glass the bank was dotted with them. I should say there were five hundred in half a mile of river' (in lit.). They congregate again before their departure in autumn, and it was doubtless to this species that Gilbert White referred in his third letter to Daines Barrington, "I saw at the time mentioned [July] many hundreds of young Wagtails on the banks of the Cherwell, which almost covered the meadows.'

\section{THE TREE PIPIT.}

Anthus trivialis.

Tne Tree Pipit is a summer visitor and fairly abundant, arriving about the second week in April. Preferring perhaps the slopes of the hills, and the bottoms of the smaller valleys, it seldom wanders far from its chosen haunt, and having once fixed upon some row of elms or spreading oak, near which upon the ground its mate will have her nest, the male may be seen uttering his sweet song from its topmost bough, or springing into the air to deliver it in his characteristic fashion, day after day all through the late spring and early summer.

\section{THE MEADOW PIPIT.}

Anthus pratensis.

The Meadow Pipit is a resident species, but comparatively few pairs remain to breed; those that do so seem to prefer the higher grounds, and I have noticed that the fields in the neighbourhood of Tadmarton Heath especially are frequented 
by Meadow Pipits in summer. Nevertheless breeding pairs may occasionally be found in various situations, and examples are observed in Port Meadow at all seasons (H. A. Macpherson, MS.). The Meadow Pipit passes us on migration in spring in small flocks, remaining but a short time, and in autumn in greater plenty. An extract from my note-book for 1886 gives some idea of this migration. On the 26 th September, and all the fine week following, 'Neadow Pipits have been passing over the village. They seem to rest and feed during the day, and about an hour before sunset you may see them in small parties, and singly, rising from the turnip-fields, and after attaining a certain height, go off south. This afternoon more than fifty passed in a very short time, many rising singly.' On the 2oth October in the same year the Cherwell meadows were full of Meadow Pipits in large flocks, but they had almost all disappeared a week later. A certain number remain during the winter months even in the most severe weather, frequenting the wetter parts of the meadows as long as any unfrozen ground exists, and the banks of the streams, and being always found on Port Meadow; at that season also they are constant attendants on the sheep folded on the arable land, where they become very familiar, running about in the pens close to the observer and often settling on the bars of the hurdles.

\section{RICHARD'S PIPIT.}

Anthus richardi.

RichaRd's Pipit, a rare visitor to the shores of England in autumn, has occurred in this county in one instance. Rennie, in his edition of Montagu's Ornithological Dictionary, published in 1831 , mentions that a specimen was taken alive at Oxford.

\section{THE SKYLARK.}

Alauda arvensis.

THE Skylark is an abundant resident, breeding very numerously, especially on the high corn lands, where in spring their 
song is heard on all sides. In autumn they resort largely to the wet meadows, and in winter flock together on the stubbles, especially those which are planted with clover to follow, and at that season their numbers are often augmented by the arrival of migratory flocks from other parts of the country; should, however, the weather be very severe, these, and, to a considerable extent, our own birds also, leave us. The Messrs. Matthews state that, "At the commencement of very severe frost vast flocks of larks leave this part of the kingdom for the south; on some days, from light to dark, the air is never free from them; the multitude which pass during that time is almost incredible.' (Zoologist, p. 2429.) Many of these flocks may have consisted of birds merely passing over the county and coming from further north. Larks do an enormous amount of good, and hardly any injury, to the agriculturist; all that can be alleged against them being that they are apt to do a little damage among newly-sown oats, as they have acquired a bad habit of digging them out of the drills.

\section{THE WOODLARK.}

\section{Alauda arborea.}

The Woodlark is a resident, but of extremely local distribution, being found only on certain parts of the Chiltern Hills, although a few are said to breed in the neighbourhood of Bablock-Hithe Ferry, near Standlake, and a female was brought thence to the Rev. H. A. Macpherson in January, I88. (MS. notes); it must, however, be very uncommon in this locality, as Mr. Warner never met with it. In the Chilterns, from the Messrs. Matthews' observations, the Woodlark appears to be found very sparingly near Stokenchurch and in a few other spots on the range, where it breeds and is resident all the year, being occasionally seen in small flocks of five or six together. (Zoologist, pp. 2597, 2736, and A. Matthews in lit.) The Rev. B. D'Oyly Aplin has also seen it near Chinnor, at the foot of the hills, in 1880. 


\section{THE SNOW-BUNTING.}

Plectrophanes nivalis.

The Snow-Bunting is an occasional winter visitor of rare occurrence. The Messrs. Matthews record it as 'seldom making its appearance except in the severest seasons,' and of late years two occurrences only have been reported. A birddealer in Oxford purchased a female from a local bird-cateher a few years ago (H. A. Macpherson MLS.), and on the 8th December, I 878, Mr. C. M. Prior shot an adult specimen at Bloxham, where it was feeding in a stubble field in company with Chaffinches (in lit.). About a month after, an adult male was shot in Northamptonshire at Aston-le-Walls, but a short distance over the county boundary.

Considering the abundance of the Snow-Bunting on the east coast of England (the shores of the Trash in Lineolnshire for instance, where $I$ have seen as many as five hundred in a flock), it is curious that it does not visit us more frequently, but it seems that the Snow-Bunting rarely wanders far inland in winter, and even in North Northamptonshire the visits of this species are rare (Lord Lilford, Notes on the Birts of Northamptonstire, p. I06).

\section{THE REED-BUNTING.}

Emberiza schoniclus.

The Reed or Black-headed Bunting is a resident, breeding commonly along the sides of our streams and pools wherever reeds and aquatic herbage or bushes and osiers are found, and is naturally more abundant in the larger valleys, where such conditions exist in greater profusion. Here in summer the male, with his russet plumage, black head, and white collar, is a conspicuous object, as, perched on some twig overhanging the water, he chants his attempt at a song, consisting of only a few unmelodious and rather monotonous notes. In winter the Reed-Buntings still haunt the streams to some extent, but range in the daytime over the higher arable fields where, and 
round stackyards, they feed, in company with the other smail birds, always retiring at sundown to roost among the dead rushes and rough hedges in the valleys.

\section{THE BUNTING.}

Emberiza miliaria.

The Bunting, or Corn-Bunting, is a common resident, breeding usually on the high-lying arable lands. All through the summer (for it is one of the few birds that will sing on until mid-August and even later), in such localities, you may hear its harsh, stridulant song, as it sits on the top of some low tree, hedge, or stone wall amid the corn-fields. In summer they are rarely found away from such spots, but in early autumn they flock together and resort to the lower grass-fields to some extent. In winter again they consort with other small birds on the stubbles, and round stack- and cattle-yards, and retire at sunset in little flocks to roost on the ground in grass-fields and rough hassocky meadows; this I believe is their invariable custom, as I have often flushed them from such situations after dark, and the batfowlers do not take them in the hedges. The Oxfordshire name for this bird is 'Buntlark.'

\section{THE YELLOW BUNTING.}

Emberiza citrinella.

The Yellow Bunting, or Yellow Hammer, is an abundant resident, nesting along almost every hedgerow, and gathering together in flocks in winter, wherever in field or farmyard there is promise of anything in the way of corn or seeds. A common wayside bird, its bright colours and drawling, monotonous song, heard from the first mild weather in February on through the whole summer, must be familiar to every one who cares for country sights and sounds. Although a very generally distributed species, the Yellow Hammer is most abundant on the upland arable country. 


\section{THE CIRL-BUNTING.}

Emberiza cintus.

TuE Cirl-Bunting has occurred in North Oxfordshire on several occasions both in summer and winter. It probably breeds in small numbers, but actual proof of this is, however, wanting. Mr. C. M. Prior has taken two nests, which he believed to belong to this species, in the neighbourhood of Bloxham, where he shot a female from a flock of Yellow Hammers in December, 1878 (in lit.). Mr. I. M. Bartlett informs me that at the end of May, I885, he saw two pairs of Cirl-Buntings near South Nerwington; he is acquainted with the appearance of the bird from having preserved specimens for me, and particularly noticed the black throats of the males. In January, I871, Mr. John Gardner shot seven or eight from a flock of ten which were feeding on some hayseeds in a field adjoining Banbury cemetery; two of these, a male and female, I have seen in his collection at Warwick. The Messrs. Mathews record that a few specimens had been brought from the neighbourhood of Osford to Mr. Forrest for preservation (Zoologist, p. 2597). In South Oxon, on the western slope of the Chilterns, the Cirl-Bunting is more numerous. A male was observed by my brothers at the foot of the hills near Chinnor on the I th July, I 879. Mr. H. Evelyn Rawson considers it fairly common in the southern corner of the county (in lit.), where it undoubtedly breeds.

\section{THE CHAFFINCH.}

Fringilla coelebs.

The Chaffinch is a resident, and one of our commonest birds. About the middle of February, if the weather is mild, the joyous, ringing song of the Chaffinch may be heard from many a roadside tree, and is one of the earliest signs of the approach of spring. Gathering together in large flocks in winter, and remaining in company to range the fields for food well on into spring, no bird is more regular in its attendance on the fie!ds 
newly drilled with spring eorn, where numbers in brilliant plumage may be seen scattered over the rich red-brown earth, together with Yellow Hammers, Corn Buntings, Larks, Greenfinches, Tree and House Sparrows, and a few Reed Buntings. With the present system of drilling, which effectually hides the seed in the ground, they cannot do much damage, and probably pick up only a little seattered grain; but when the corn was sown broadcast and afterwards less perfectly covered by the action of the harrow only, a considerable quantity was doubtless eaten by the birds, and one cannot help wondering if the tradition of good feeds on newly-sown fields has been handed down among them from pre-drilling days.

It was formerly believed that the sexes of the Chaffinch separated during winter, and this appears to be the case in Northern Europe but not generally in England. I have on one or two occasions in winter met with small flocks composed entirely of hen birds, which were probably immigrants from Seandinavia.

The Chaffinch is known in Oxon as the 'Piefineh,' from its pied plumage, and also as the 'Peafinch,' pronounced 'Payfinch,' perhaps from its occasional depredations among young peas. Any damage, however, that it may do, and it is very slight, the Payfinch makes good over and over again by destroying innumerable caterpillars (upon which it feeds its young almost entirely) and other insects; it is perhaps our most insectivorous finch, and one of our most useful birds.

\section{THE BRAMBLING.}

Fringilla montifringilla.

The Bramble Finch, or Brambling, is a winter visitor of irregular occurrence. In some years hardly any will be noticed, while in others very large flocks appear. On their first arrival Bramblings haunt the vicinity of beech trees, feeding greedily on the fallen mast, and it is said that in 
districts where the beech is a common tree their numbers in any year depend upon whether there is a plentiful supply of mast or not. Bramblings usually arrive in this county in October, but in this (northern) division, where the beech only exists as a planted tree, although an occasional bird may be seen in that month, the large flocks do not appear until about Christmas, when, the beech-mast being exhausted, they range widely over the country in search of food. Then they appear on the stubbles and ploughing's, consorting when few in number sometimes with Chaffinches and other birds, but when in large flocks generally keeping by themselves. When a flock is approached, and the birds flit on in front of the observer, they bear a striking resemblance to Bullfinches, the white patch on the lower back being very noticeable in flight. They remain with us often until the begimning of March, and I once saw a fine male on a nervly-drilled field at Great Bourton on the I6th of that month, a remarkably warm day, in 1884. Bramblings are very hardy birds, and some specimens which I examined during the severe frost of January, I88I, when many birds were dying of cold and starvation, were quite fat. Very large flocks sometimes visit us. About the end of February, I886, forty were taken one night in bat-fowling or clap-nets at Wroxton, and of one hundred and seventy small birds, killed at three discharges, near Balscott, in the early part of March that year, all but a few were of this species. It is worthy of note that nine-tenths of the Bramblings shot here are males, and a very large percentage of them are adult birds. In its ordinary plumage the throat of the male Brambling is of the same orange fulvous colour as the breast, but two peculiar varieties, or phases, of phumage have been noticed by ornithologists: in one the throat is more or less black, and in the other white. I possess Oxfordshire specimens exhibiting both these phases, which were procured in March, 1886, and January, 1888. 


\section{THE TREE SPARROW.}

Passer montanus.

The Tree Sparrow is a common resident, generally distributed, breeding in various situations but generally in holes of trees, especially in the apple and in pollard willows by the streams, nesting also in the roofs of cattle sheds or hovels, and, as Mr. C. MI. Prior has observed, in old Magpie's nests. In its breeding habits it is somewhat local, several pairs generally nesting in close proximity and often forming little colonies. The late Rev. T. W. Falcon at Charlton-onOtmoor noticed them 'breeding in small fraternities in holes of the thatch of outlying eattle sheds' (in lit.), and I knew of one such among the timbers of a girder bridge where the railnay line crosses the canal near Banbury, and of others in orehards, and rows of pollard willows. Mr. J. E. Harting writes of a colony existing for many years at Standlake. 'Of twenty nests taken there, one was in a faggot-stack, one in a hole of a decayed elm, two in holes of pollard ash, four in holes of pollard willow, and twelve in holes in decayed apple-trees in orchards' (Intullbook of British Birds, p. xvi). Mr. Naruer informed me that two broods were reared at that place in a small hole in an apple-tree in his orchard in $\mathbf{I} 883$ (MS.). In winter Tree Sparrows gather together in little flocks, and when joining other species prefer the company of Greenfinches to that of other birds. They are usually found roosting in the tall hedgerows and ivied hedgerow trees. Mr. Falcon wrote, 'In winter they come into my garden and roost, not with the other Sparrows in the ivy, but by themselves in solitary evergreens' (in lit.). I have also known them taken when roosting in holes along the eaves of cattle hovels in the fields. The Tree Sparrow is a shy bird, and when disturbed in the hedgerows generally flies up to the very top of the tallest tree near. 


\section{THE HOUSE SPARROW.}

\section{Passer domesticus.}

The House Sparrow is a resident, steadily increasing in numbers. The enormous amount of damage done by the swarms of Sparrows found in this agricultural county is perhaps hardly realized, although a walk down the side of a field of ripening wheat near a village or homestead will reveal plenty of evidence of the destruction wrought by them, in the shape of wheat ears as completely emptied of their contents as if they had already been through the threshing machine.

The Sparrow question is too long to be entered upon fully here, but those interested in the subject may peruse with advantage 'The House Syarrou', by MIr. J. H. Gurney, jun., Col. C. Russell, and Dr. Elliott Coues; 'The Sparrow Shooter,' by the Rev. F. O. Morris ; and 'On the Misdeeds of the Sparrow', by Mr. J. H. Gurney, jun. The first and last of these publications are against, and the second in favour of the Sparrow. It is sufficient here to say that the careful inrestigations carried out, chiefly in Norfolk, by Mr. Gurney, and communicated as above, and in a paper read before the Norfolk Chamber of Agriculture (Norfolk Chronicle, Ist August, I 885), prove that the customary food of old Sparrows consists of corn in every month of the year, varied in some months with vegetable matter and seeds. The young in the nest are fed upon caterpillars, beetles, and other insects, but also quite as much upon ripe and unripe corn, the soft milky grains of wheat and barley being found in their crops in July. Gardeners have plenty of complaint against the Sparrow, and few ornithologists have a good word for it. The rapid increase of the Sparrow must have the effect of checking that of some of our other small birds, and not only indirectly so, for it is not wholly guiltless of attacking and tyrannizing over weaker and more gentle birds; House Martins especially 
are frequent sufferers, being often ejected from their nests, and this in some places has been carried to such an extent as to seriously affect the numbers of these graceful and most. beneficial insect-eaters. The Sparrow is all very well in its place, but it has clearly increased out of all due bounds, and the sooner properly managed Sparrow Clubs are revived in every parish the better for the farmer, the gardener, and the bird-lover; combined effort alone can thin the Sparrow's numbers, and make way for an increase of other more useful species.

Many birds are taken in Oxfordshire at night with 'Batforwling,' or as they are always called with us, 'Clap-' nets, a name more properly applied to the nets spread on the ground and used with call-birds in the daytime. Bat-forling nets are figured by Tarrell (4th edition, vol. ii. p. 97), but as the mode of using them practised in this part of the country differs from that there depicted (which is, I believe, the most usual one, viz. with a lantern on a dark night), a description of the Oxfordshire method is here given.

A bright, clear, still, moonlight winter's night is chosen, the lighter the better, the few nights preceding the full moon being considered the most favourable, as the moon is then high early in the night. Four or five men or boys generally go out together. One carries the net, one is freehanded, being employed in taking the birds, when caught, out of the net, and the other's are furnished with long poles. Arrived at their humting-gromds, the great tall straggling hedges, unlaid for some years, which separate many of our pastures, the man with the net and his helper go on one side of the hedge, and the pole men on the other. 'The former, keeping the hedge as far as possible between him and the moon, and carrying the net open, the poles over his shoulders and his head inside the lower part of it (his hat being firmly tied on to prevent its being pulled off), proceeds quietly down the hedge side, and is thus enabled to see the birds as they sit at roost on the 
twigs, their dark forms silhouetted against the moonlight. When he sees a bird he lifts the net free of his head, and directs his assistants on the other side to beat with the poles; the frightened bird flying out is secured by a quick stroke of the net, which is clapped together. The birds sometimes sit so close that they have to be pushed off their perches. In this way the birdcatchers will take twenty or thirty birds, and often more, in a night. The species most commonly taken are Blackbirds, Song Thrushes, Redwings, Chaffinches, Greenfinches, Limets, Bullfinches, Tree Sparrows, and Long-tailed Titmice; occasionally a Magpie is secured. Fieldfares are very seldom taken, they are so wary, almost always flying out before they can be approached. Although Yellow Hammers roost in the hedges in hundreds comparatively few are caught, as they can seldom be induced to fly out at the side of the hedge but flutter up to the top before leaving it. House Sparrows are taken round the ricks, eattle hovels, and in ivied walls, being beaten out at random. Many villagers are extremely fond of this diversion, and after a long day at ploughing or other field work, will sally forth again in the evening and range the frosty fields until nearly midnight.

\section{THE HAWEINCH.}

\section{Coccothraustes vulgaris.}

THe Hawfinch was formerly considered to be merely a winter visitor to this county, but of late years it has been found to be a resident throughout the year, breeding sparingly in many localities; at the same time, as will presently be shown, in some winters, when they are unusually abundant, we are visited by migratory individuals.

In 1849 the Messrs. Matthews included the Iawfinch in their list of residents, with some hesitation on account of its rarity, but they mention its appearance at all times of the year, and that its nest had been found near Oxford (Zoologist, p. 2429). A Hawfinch's nest was taken many years ago close 
to Banbury, the young from which were seen by Mr. W. Wyatt, in a cage, and another was reported to have been found in a shrubbery at Bodicote in 1878 , since which date many instances of these birds having been seen in spring and summer have come under my notice. A pair stayed for some time in a garden at Kingham, but departed without breeding (W. W. Fowler, MIS.). In the neighbourhood of Standlake the Harfinch occurs frequently; a specimen was caught near Gaunt Ilouse in May, $188_{3}$, and a young bird of the year was brought in by a cat on the 16th July, I876 (W. II. Warner, MIS.). The late Lord Say and Sele's keeper at Broughton Castle told me in I88 I that Hawfinches had bred there for the last two or three years, and he had shot the young just after they left the nest, being requested to do so by the gardener, whose peas they had ravaged. It has been seen by the Rev. II. A. Macpherson in May in Wychwood Forest, where I caught a glimpse of one in June, I 882. At Shotover Hill a nest and eggs were taken by Mr. W. C. Darbey in s 885 , and a brood of young were reared close to the house at Nuneham Park in 1887 (E. W. Harcourt in lit.). At Bodicote I saw one in March, I887, and a pair shot there at the end of the month probably intended to breed. In the following year a pair were again observed in the same place on the I 5 th April, but the nest was not discovered.

In the winter of $1878-9$ a few specimens were procured in the north of the county, and in that of I $880-1$ they were unusually abundant, about twenty being taken to the Banbury birdstuffers, most of which were picked up dead in a starved condition. That these birds were migrants is tolerably certain, from the fact that all of them were very much more brightly coloured than our home birds, and this remark holds good of other specimens killed here in different winters. Where these immigrants can have come from is not clear, since specimens from Northern Europe are said to be dull coloured, and but slightly brighter than British examples, the very brightly coloured birds being 
found in Southern Europe (Yarrell, vol. ii. p. IO2), whence we should not expect the arrival of migrants in winter.

The Hawfinch feeds largely on the fruit of the hawthorn and cherry, and other stone fruits, but, unlike most fruit-eating birds, it rejects the pulp and confines its attention to the stone, which, with its wonderfully powerful beak, it splits with great ease, and devours the liernel. Of this remarkable fact there is abundant proof. Having on one occasion disturbed a Hawfinch from a hawthorn bush near Clattercote, in February 1884, I searched the ground underneath the tree, and found numbers of haws bitten open; none of the pulp was eaten, but the stones were split and the kermels extracted. I have also, on the few oceasions on which I have had an opportunity of examining the contents of these birds' crops, always found kernels of some kind in them. The keeper at Broughton, mentioned previously, who is a very observant man, told me he had seen the Hawfinches pick up damson stones under the trees, and turning them round in their beaks until they got them edgeways, split them with great ease. To any one who has ever tried to erack a haw-stone it is indeed surprising that this comparatively small bird should have sufficient strength in its beak to split them (vide Zoologist, I888, p. I 48). Hawfinches will also eat various seeds. In severe weather, in the early part of 1879 , a female bird came to feed on a patch of ground kept clear of snow, where I daily fed many birds, and was seen by my brother to attack and drive away a Blackbird from a meaty bone, upon which she sulsequently fed; a male bird joined her another day, remaining for some time, and a week or two later we enjoyed the rare treat of a lengthened observation of this shy and wary species peeking about on the lawn beneath a holly tree, doubtless in search of fallen berries and stones.

From its great shyness the Hawfinch easily escapes observation, and it is not unlikely that some numbers breed with us annually. The deep glades of Wychwood Forest about 
Cornbury Park, and the thicker portions of the Chiltem woods, where the hornbeam (the seeds of which are a favourite food of this bird) is a native, neither of which localities have been thoroughly investigated by the ornithologist, may be indicated as likely to harbour the Hawfinch in some plenty.

\section{THE GREENFINCH.}

Coccothraustes chloris.

TuE Greenfinch is an abundant resident, breeding freely in gardens and in the hedgerows, and is found in considerable flocks in the fields, and round stackyards, during the autumn and winter months. Greenfinches are remarkably fond of the seeds of the sunflower, and will sit by the hour on a large seed head quietly extracting and shelling the seeds one by one, and resorting daily to the same spot until the supply is exhausted.

\section{THE GOLDFINCH.}

Carduelis elegans.

TuE Goldfinch is resident as a species, but as to individuals it is migratory to a considerable extent. Two races of Goldfinches are well known to our bird-catchers, the large, handsome, light-coloured birds which appear in spring and leave us again in autumn, wintering in the sonth, and a smaller and more dusky resident race which remains here during the winter.

A few years ago the Goldfinch had become exceedingly searce in North Oxon in summer, and several years passed in which I did not see a single bird in the breeding season, but during the last three or four years it has been steadily increasing and is now almost common again. Last summer (I887), I noticed as many as four pairs in the course of a short walk in this parish. Mr. Fowler has also noticed an increase in the breeding birds at Kingham, where they were scarce. In some of the more sechuled parts of the county 
Goldfinches seem to have always kept up their numbers, as for instance about Standlake, where they were noticed as 'quite common' by Mr. Warner. The birds which have wintered in the south return early in March, and in September and October flights of large light-coloured birds haunt the thistle-grown pastures. At the latter season great numbers are taken by the professional bird-catchers. In the antumn of 1882 , no less than twenty-six dozen were netted by three Oxford bird-catchers (H. A. Macpherson, MIS.), and in I884 one Banbury man alone took one hundred and sixty Goldfinches in September and October; these were almost all of the large race, which this man states he never takes in winter. Those that remain with us during the latter season are generally seen singly, or two or three together, but occasionally in small flocks even in severe frost. About a score were seen on the hills above Chinnor on the 3 oth January, I 880 (B. D'O. Aplin in Tit.), and I have seen a 'charm' of five-andtwenty in December, I882. The Rev. H. A. Macpherson also has recorded a charm of fifteen seen by him during a protracted frost (Zoologist, I883, p. 337). These winter birds are invariably of the small dusky race.

The Goldfinch is subject to considerable variation in plumage, certain phases of which are well known. The Rev. H. A. Macpherson mentions in the Zoologist an old bird in black plumage taken by a Hinksey bird-catcher, also the capture in September, I877, of one with the breast tinged with golden yellow (1883, p. 337). Mr. Macpherson remarks in the same note that, as far as his observations went, the crimson band across the occiput occurs only in cage-moulted males, but I shot a male exhibiting traces of this peculiarity at Great Bourton in September, I885. I have not known the true 'cheverel' to occur in Oxon in a wild state, but some years ago I purchased of Mr. W. Wyatt, of Banbury, a good example of the 'pea-throat' or 'bastard eheverel.' 


\section{THE SISKIN.}

Cartuelis spimus.

THE Siskin is a winter visitor, appearing in small numbers in most years. During their stay with us they usually frequent the banks of streams, feeding in company with Lesser Redpoles on the seeds of the alder: when thus engaged they admit of a very close approach. In the winter of 1847 , Siskins were unusually abundant in the neighbourhood of Oxford, where several instances of these birds remaining to breed have been reported (Zoologist, p. 2429). This statement respecting their nidification was made upon the authority of Mr. Forrest, an Oxford bird-stuffer (Rev. A. Matthews in lit.). It is very possible that some pairs may remain in Oxfordshire to breed, and in 1879 I observed a small party of eight Siskins in some larches at Bodicote as late as the 2oth April.

\section{THE LESSER REDPOLE.}

\section{Linota rufescens.}

The Lesser Redpole is for the most part a winter visitor, but in several instances it has been observed during the summer months, and the nest and eggs have been taken on two occasions at least. The Messrs. Matthews on one occasion sarv a family of full-fledged young with the parent birds, and remark that Redpoles were common enough in winter (Zoologist, p. 2429). In May, I882, a nest containing two eggrs was taken at Marston, the old birds flying close up to the nest on the eggs being handled (Zoologist, I 883, p. 30), and in the same year Mr. Stephen Salter, who is well aequainted with this bird, wrote word to the Rev. H. A. Macpherson that he had seen on several occasions in the Parks at Oxford 'several large parties' of Lesser Redpoles in the middle of July (H. A. Macpherson in lit.). From the same locality my friend Mr. J. R. Earle had a nest containing five eggs in June, I 883 (in lit.), and Mr. W. W. Fowler saw a pair there 
in the summer of 1885 , which he believed were breeding. The Oxford Parks abound in birch and various other trees which are attractive to this species. In the north of the county the nest of the Redpole has not been discovered, but a female was shot at Bloxham Grove on the I4th April, 1887. In autumn the migratory Redpoles arrive in October, and are not at all uncommon on the banks of streams where the alder abounds.

The large light-coloured race of Redpoles has occurred in Oxfordshire, and some were in the hands of an Oxford birddealer in the winters of $1879-80$ and $1880-81$ (H. A. Macpherson in lit.).

[The Mealy Redpole (Linota linaria) has not, as far as I am aware, been procured in this county.]

\section{THE LINNET.}

\section{Linota cannabina.}

The Linnet is a common resident, a certain number breeding generally all over the county in hedgerows, and especially where furze bushes abound. In the breeding season, however, it is only in the wilder portions of the county that it is found in any numbers. On the slopes of the Chilterns, Shotover Hill, and similar situations, it is abundant, and on Wigginton Heath, when the broom is one mass of golden blossom, the Linnet is a characteristic feature, its sweet twittering song being heard all around. In autumn and winter the Linnets descend to lower ground, and flock with other small birds in the fields, and at that season they probably receive additions to their numbers from more northern localities, as considerable flocks of this species alone are sometimes seen. The Linnet is known as the 'rose,' 'brown,' or ' grey' Limnet, according to sex, and the plumage worn at different times of the year. Those old males in which the red on the breast and head is of a brilliant carmine tint, are seldom met with.

[The Twite (Linota flaviostris) is included in the History of 
Banbury list. It is quite possible that it may have occurred in winter, but I have never met with it, nor have I heard of any instance of its being procured in the county, and it is a bird which would not easily be overlooked by any one acquainted with its note and appearance.]

\section{THE BULLFINCH.}

\section{Pyrrhta europaed.}

THe Bullfinch is a resident, seen commonly about the tall hedgerows in winter, and in spring in gardens, but retiring to the roods and spinneys during the breeding season. At that time of the year therefore they are seldom observed, as they always choose the most secluded spots. In I 886, however, a pair, forsaking their usual habits, nested in a thick belt of yew trees which border a much frequented path in Mr. F. C. Aplin's garden at Bodicote, within a dozen yards of the house. In some years the number of our resident Bullfinches is augmented by an influx of strangers. This was the case in October and November, I 880, when many were caught by the bird-eatehers about Headington (H. A. Macpherson, MS.), and in the winter of $188_{4-5}$ when they were unusually abundant about Great Bourton, and numbers were taken by the bat-fowlers. Again, in October, I 887, Mr. W. Warde Fowler met with 'a little pack of Bullfinches, ten or twelve,' a circumstance which had only come under his notice once before (in lit.). At the end of December, I888, I observed a little flock of about a dozen Bullfinches, chiefly males, in this parish. A very beautiful male Bullfinch in my possession was taken at Great Bourton on the 27 th November, 1884. In this specimen the rose colour of the breast reappears in the form of a narrow edging to each grey feather of the mantle, producing a most beautiful appearance when the bird was fresh and before the tints had faded, as they always do in preserved specimens of this species. 


\section{THE COMIMON CROSSBILL.}

Loxia curvirostra.

The Common Crossbill is an occasional visitor of extremely irregular appearance, both in the season at which it visits us, and in the numbers which arrive. The Messrs. Matthews record that ' on the I9th July, 1838 , a small flock of Crossbills came to this village [Weston-on-the-Green], and remained here until the middle of the following December .... The plumage of the young birds, when they first appeared, was of a dingy green colour, speckled throughout, much like the common Woodpecker of the same age; the old males at that time exhibited their gayest tints of red and yellow.' (Zoologist, pp. 2597-8.) The appearance of the young birds in July must not be understood as affording any proof that they had been bred in the county, or even anywhere near, for the Crossbill goes to nest very early in the spring-almost in winter-and commences its wanderings over the country quite early in summer. From the evidence contained in a letter from the late Mr. W. Proctor, of Durham, to the late Mr. T. C. Heysham, of Carlisle, dated I 3 th December, 1839 (an extract from which has been kindly furnished by the Rev. H. A. Macpherson), there is some reason to believe, however, that Crossbills may have nested in Oxfordshire in I839. Mr. Proctor writes, 'I have just had a box from a correspondent from Oxfordshire, who obtained the eggs of the Crossbill this last summer. I have got three, but they are not blown, they resemble those of the green Linnet.' This evidence, it must be confessed, is merely presumptive. A flock of five Crossbills appeared in a larch spinney by the side of the canal, a short distance below Banbury, in December, 1873, and were all shot; and a male and female were killed near Broughton in the winter of 1878 or 1879 . In I866 a large flock of forty or fifty were observed on the I2th August, at Park Place, Henley-on-Thames, on the Berkshire side of the river, where they remained two or three days (Zoologist, ss. p. 523). 
I did not hear that any Crossbills were noticed actually in the county during the year I 888, when these birds were observed in unusual numbers in different parts of Great Britain, but three were shot close to our borders at the end of December; of these, two were obtained near Lechlade, and the third in the neighbourhood of Abingdon.

\section{THE STARLING.}

Stumus vulgaris.

The Starling is an abundant and increasing resident, breeding in numbers in holes in trees and buildings, alike in towns and villag'es, and in the fields and woods, and at the close of summer gathering together in flocks which, augmented by migratory individuals, haunt the meadows and open country in mild weather from autumn to spring; in severe seasons comparatively fer remain during the winter. The flocks sometimes seen in autumn are of vast size, and in March again they are even larger still, especially if the weather has been cold and stormy and the valleys flooded, when, together with Rooks, Pewits, and Fieldfares, they fairly blacken the meadows.

The flocks roost often on the fallows, and in plantations, and also in reed-beds, as at Clattercote Reservoir. 'Thither they resort about sundown, and after flying backwards and forwards over the water for a few minutes, and wheeling about with the greatest rapidity, the flock suddenly descends, and, as it were, pours into the reed-bed, whence instantly arises the chatter of hundreds of tongues, mingled with fluttering and shuffling of wings, which continues until all have found a convenient roosting-perch, when silence reigns again. Starlings do not usually leave their roost until broad daylight, when the Lark has been on the wing a full hour.

The enormous increase of this bird, not only here but almost everywhere in England, has been generally remarked upon. No bird does more good to the agriculturist, consum- 
ing as it does vast numbers of worms, grubs, and insects at all times of the year; but, if the Starling continues to increase at its present rate, it is not impossible that it may be forced to somewhat change its mode of living, and, should it begin to attack the crops to any extent, the consequences would be serious. At present a charge of occasional fruit-eating only can be brought against it; as for instance in the dry summer of 1887 , when the ground was baked so hard that worms could not be obtained, and the Starlings attacked the cherries. The rapidity with which they cleared the trees was astonishing. That they will eat corn in winter is quite certain, for I have found it in their crops. Some ornithologists are beginning to look askance at the Starling, firstly because it has been detected (as my friend Mr. Whitaker tells me) in the act of carrying off young Sparrows from the nest, and secondly from its habit of usurping every available breedinghole, to the exclusion of all other birds affecting such situations. No other bird is so aggressive in this particular, none so pertinacious and unwearying in its endeavours to attain the end in view. I have known a pair of Starlings spend hours in obtaining a desirable hole already occupied by some other bird, and at last carrying their point by wearying out the patience of the rightful occupant. They will even induce the house Pigeon to vacate in this manner. A very mocking bird, in addition to its own chattering song and long-drawn whistles, it imitates the notes of many birds. The Messrs. Matthews give the following: Peewit, Wryneck, Blackbird, Jackdaw, Kestrel, Thrush, Moorhen, Coot, and Partridge; I can add the keewak of the Barn Owl, and Mr. W. W. Fowler the Nuthatch.

\section{THE ROSE-COLOURED PASTOR.}

Pastor roseus.

THe Rose-coloured Pastor is a rare occasional visitor. First noticed in England in 1742, Shaw figured it in 1796 in the 
Naturalist's Miscellany, stating that one had been shot the year before in Oxfordshire. One shot near Oxford in the spring of 1837 was in the collection of Dr. Kirtland, who informed the Messrs. Matthews that another was shot in the same neighbourhood in February, 1838 (Zoologist, p. 2598). With reference to this occurrence the Editor of Iarrell's British Bimls remarks in a foot-note, "If there be no error the example may have been one that had wintered in this part of the world ' - the visits of the Rose-coloured Pastor to England having usually taken place in summer. I have seen an adult specimen in Mr. G. Arnatt's collection, which was shot by his brother at Stanton Hareourt, out of a flock of Starlings, 'about forty-five years ago' (in lit. I 888); and another procured at Ewelme, some five-and-twenty years since, is in the collection of Mr. W. Newton, jun. (in lit.)

\section{THE ALPINE CHOUGH.}

\section{Pyrhocorax alpinus.}

TuE Alpine Chough has oceurred in Oxfordshire on one occasion, namely, at Broughton, where a female was shot in the Park on the 8th April, I88I. It was sent to a village bird-stuffer in Bodicote, named Gunthrop, and I had an opportunity of examining it in the flesh the same day, and of dissecting the body after it was skinned.

The Alpine Chough has not been procured in Great Britain on any other occasion. It is an inhabitant of the larger mountain ranges of Europe, and is met with in Asia in the elevated portions of the Himalayas (Dresser, Birts of Europe). It has been stated that its habits are not in any degree migratory. At the time the Broughton example was recorded, it was thought that this was an extremely unlikely species to wander to our shores, and, having regard to the fact that these birds have been kept in confinement in England, many ornithologists were of opinion that the specimen in question 
was merely an escaped bird: I could not, however, hear of any caged examples having been lost about that time, and Lord Lilford, who had some at Lilford, informed me he had not lost any. In appearance our bird showed no signs of ever having been confined in an aviary. The umrubbed and beautiful condition of the plumage perhaps does not prove much, but the feet, which in caged birds are often affected, and almost always have long unworn claws, were those of a wild bird; the body was well nourished but not unduly fat. Above all, the food which I found in the stomach was perfectly consonant with the natural habits of this species, consisting of remains of small beetles and one caterpillar, entire, about an inch long. Since the occurrence of this specimen in Oxfordshire, the Alpine Chough, as Mr. J. Cordeaux kindly informs me, has been recorded to have occurred twice on the island of Heligoland, a spot noted for the numbers of rare spe ies, otherwise almost unknown in Western Europe, which have been procured there (Bulletin de la Société Zoologique de France, t. vii, 1882). Now this fact is very important; for the connection, in regard to the migration of birds, between Heligoland and the east coast of England is so intimate, and corresponding migrations affecting both localities have happened so often (vide J. H. Gurney, jun., Trans. Norfolk and Norwich Naturalists' Society, vol. iv. p. 52), that the improbability of the Alpine Chough visiting England as a casual wanderer is thereby greatly diminished. And it is submitted that the claim of this species to a place on the roll of our British Birds is at least as good as that of some others, the appearance of which in this country is equally unusual and improbable, but whose place among our avifauna has never been disputed. To some extent its claims have already been conceded; for Mr. Seebolim makes some reference to the occurrence, and figures the egg of the bird, in his History of British Birls (vol. i. p. 580), and in the latest revised list of British Birds it is included, in square brackets, 
in the same category with some other species whose right to inclusion is considered doubtful by the compiler.

The Broughton specimen was sold by Gunthrop to Mr. Wyatt, the Banbury taxidermist, and by him to Mr. J. Whitaker, of Rainworth Lodge, near Mansfield, in whose collection it now is, and to whose kindness I am indebted for a coloured drawing of it, by Mr. S. L. Mosley, from which the plate given as a frontispiece to this volume has been prepared by the same artist.

The notes in the Zoologist for I88I, pp. 422 and $47 \mathrm{I}$, and for 1882, p. $43 \mathrm{I}$, have reference to this specimen.

[The Red-Billed Conxisi Chough ( $P$.graculus) has not occurred in Oxfordshire.]

\section{THE RAVEN.}

Corvus corax.

Trre Raven is now quite extinet as a resident in this county, and even as a casual visitor its occurrence has, as far as I know, only been noticed in one instance of late years. Writing from Wreston-on-the-Green in I849, the Messis. Matthews say that it was then seldom seen, adding that 'a few years ago five passed over this place in company, and single specimens are still oceasionally met with. In 1834 four young birds were taken from a nest near Oxford' (Zonlogist, 1. 2598). Mr. C. E. Ruck-Keene informs me that he has a specimen which was shot at Swyncombe in I84I (in lit.). In former days the Raven must have been a common bird, and the name 'Raven Hill,' occurring near Deddington, seems to denote a former famous breeding haunt. A Raven was shot at Astrop, about a mile over the Northamptonshire boundary, near Adderbury, about the year 1877, but the last Raven killed in Oxfordshire of which I am arvare was shown to me in March, I888, at Burford, near to which place it was shot in the winter three years previously. 


\section{THE CARRION CROW.}

Corvus corone.

THe Carrion Crow is a resident for the most part, but leaves us almost entirely in severe weather. Its numbers depend locally upon the extent to which game preserving is carried on. In the north of the county, where the Crow has it all its orw way, it is particularly abundant, and here loses much of the solitary habit usually attributed to it, being seen commonly, except in the breeding season, in small flocks. On 18 th October, I883, I counted no less than thirty-two feeding in a stubble field at Great Bourton, and on the afternoon of the 28th December, I884, my brother and I saw an assemblage of Crows, which we calculated must have numbered 200 at the least, collected in some trees near a well-known roosting haunt. These I am inclined to consider consisted chiefly of passing migrants on their way south, as there were but few about the roost the evening before.

This particular roosting-place, a spinney of tall oak trees in this parish, has to my knowledge been resorted to regularly for the last ten years. About dusk the Crows collect in the outlying trees, arriving with much loud croaking, taking short flights, and often sailing over the spinney without alighting. As the darkness increases a few fly in and settle in the tree tops, to be followed shortly by the rest, and, noisy as they are outside, they always fly in quite silently; often as I have stood under the trees as they came in, I have never heard them utter a sound.

The Crow pairs rather early in spring, and on the wild windy days in March a couple of pairs may be seen disputing for the possession of some little grove or row of trees; wheeling round with loud and angry croaks, twisting in and out of the bare branches, and swooping down savagely as one or other settles for a moment. The observer can almost fancy the days of the Raven back again. Although pairing early 
the Crow is generally rather a late breeder, and is said to delay nesting until the end of April or the beginning of May; but here it often goes to nest earlier, and I have found eggrs much incubated by the 24 th of the former month.

There can be no doubt as to the destructive habits of this species, and the amount of damage which it does among game and wildfowl during the breeding season is very considerable: at that season the Crow may be seen regularly beating the fields, stream banks, and hedgerows in search of nests, the eggs and young birds being equally acceptable to it. In the summer of 1883 , I chanced upon the feeding spot of a pair of Crows which had reared their young at Clattercote Reservoir. Strewn around were the remains of several frogs and toads, together with a fledgling Finch, and a number of broken eggshells of the Partridge and Wild-duck. In the poultry-yard it is equally destructive, and I have seen a Crow carry off a duckling some th_ee weeks old, in spite of the old duck's gallant defence of her young.

It must be remembered, however, that during all the rest of the year the staple of the Crow's food consists of worms, grubs, and insects. Crows are fond of the large fresh-water mussels (Anorton and Unio), which they find cast up on the meadows after floods, and also search for in the mud at Clattercote when the water is low, reminding one strongly of the habits of their congeners, the Hooded Crows, on the coast.

I have been somewhat diffuse in describing the habits of this common bird in Oxfordshire, which may be easily observed, simply because in many parts of England, where game preserving is largely carried on, the Crow is really a rare bird, and at some future time may be so even in this district.

Distributed in some numbers all over the county, it is nowhere so plentiful as in the north. About Kingham it is 'hardly common' (W. W. Fowler, MS.), and it only occurs sparingly in the neighbourhood of Standlake (Warner, MS.). The usual local name is Gor Crow. A pair nest regularly in 
a tree in the grounds of the University Observatory at Oxford (W. W. Fowler).

\section{THE HOODED CROW.}

Corvus cornix.

The Hooded, Grey, or Royston Crow, is an uncommon winter visitor, arriving about the middle of October. A few examples only are noticed in any season, and in some none at all. In the cold spring of 1886 they remained unusually late, one being seen by Mr. A. II. Macpherson feeding with Rooks in Christ Church Meadow on the $13^{\text {th }}$ March; another was shot in the neighbourhood of Oxford two days later, and on the 3 oth a third was shot near Banbury. Early in the following September, a Grey Crow was shot at Oxford, and it is possible that this species, which has been known to breed no further from us than Warwickshire, may have nested somewhere in the vicinity of, if not actually in, the county that year. It is known in the upper Thames district as the 'Dun Crow' (Warner, MIS.).

\section{THE ROOK.}

Corves frugilegus.

The Rook is a numerous resident, almost every parish possessing its Rookery or Rookeries, the young, or 'branchers,' of which are shot in favourable springs on or about the 12 th May. In very severe weather with deep snow a partial migration of our Rooks sometimes takes place, and of those that remain some often die of starvation, as for instance in February, I888, when many were picked up dead.

It is not desirable to enter here at any length upon the much vexed question of whether the Rook is more injurious or beneficial to the farmer. The harm they do at times is sufficiently obvious to the agriculturist, but it is for a short season only that they can do any damage to the crops, and all the rest of the year they are performing services which they alone could render. The worms and grubs brought to their 
young alone must amount to an incredible number, and the great flocks of Rooks seen in our pastures and meadows during the greater part of the year, must rid them of countless destructive grubs and insects. Many a root crop too, attacked in early autumn by wireworms, and that dark grey grub which is so injurious, is saved by the Rooks. I am glad to think that most Oxfordshire agriculturists seem fully aware that when the balance is struck between the good and evil done by the Rook, it is largely in its favour.

The good deeds of this bird were not, however, recognized in former days. By the Statute, 24 Henry VIII. cap. Io ( 1532 ), all persons occupying lands were enjoined to kill and destroy all choughs, crows, and rooks which did ' yearly devour and consume a wonderful and marvellous great quantity of ' 'orn and grain of all kinds.' And the Act provides that every parish should provide 'one net commonly called a net to take choughs crows and rooks,' and lay the same at the times and places convenient and expedient for the destruction of the birds. The Crow-net is figured in Tillughby's Omithology (I678). Dr. Plot, deseribing the 'arts' relating to corn in this county, writes, 'If the Crows towards harvest are anything' mischievous, as they many times are, destroying the corn in the outer limits of the fields, they dig a hole narrow at the bottom, and broad at the top, in the green swarth near the corn, wherein they put dust, and cinders from the Smith's forge, mixt with a little gunpowder, and in and about the holes stick feathers (Crow-feathers if they can get them), which they find about Burford to have good success' (Natural History of Oxon, ch. ix, §98). But whether this was to frighten the Rooks, or to catch them, does not appear.

\section{THE JACKDAW.}

Corvus monedula.

THE Jackdaw is a common resident, breeding numerously in the hollows of old elm and other trees, and also in buildings, 
and the towers and steeples of many a village, town, and city church; in this parish for instance, where the Daws may often be seen circling round the spire quite up to the summit, nearly two hundred feet high, where they look no bigger than Starlings. In Oxford it is a well-known resident.

Jackdaws and Barn Owls sometimes quarrel for the possession of a convenient hollow tree; at Bloxham Grove one of the latter birds was (whether intentionally or not it is difficult to say) built into a large hollow in an old elm in front of the house. The presence of the Daws in that particular tree being undesirable, a man was sent up to remove the mass of sticks deposited in the hole, at the bottom of which he found a Barn Owl in a very weak state, and only just able to fly away. I once saw a Jackdaw's nest built under the eaves of a wheat rick, in a hole apparently excavated by the birds, a most unusual situation. In winter Jackdaws are seen in little flocks accompanying the Rooks to their feeding-grounds.

\section{THE MAGPIE.}

Pica mistica.

The Magpie is a resident, and probably in few parts of England is it so abumdant as in the north of the county in this neighbourhood. When the leaves are off the trees in winter, the large domed nest of the Magpie is a common and conspicuous object, both in tall trees, and in the thorn bushes and big hedgerows. At that season Magpies are more or less gregarious, and always so at roosting-time. It is no uncommon sight to see as many as a dozen birds together even in the daytime; I once indeed counted twenty-six as they flew one after another out of a row of trees on the $24^{\text {th }}$ December, I 88I, and Mr. C. M. Prior saw thirty-four in a stubble field in November, I 875 (Zoologist, ss. 1. 4879). The abundance of the Magpie in this district is owing to the fact that strict game preserving is almost unknown, and many a Partridge's nest is harried by these worst of egg-stealers. The Magpie is 
a common bird all over the county, though generally speaking not so plentiful as in the district already spoken of, and in some parts it is far less so.

Robert D'Oyly the second founded Osney Abbey, near Oxford, because 'a company of Pyes' which had repaired to a certain tree standing in the meadows there, were 'alwaies so clamorous' when the Baron's wife passed the tree, and she consulting with one Radulphus, Canon of St. Frideswide's, was advised by him that it signified that she should build some Church or Monastery where the tree stood. (Plot's Natural History of Oxfordstire, p. I69.)

\section{THE JAY.}

\section{Garrulus glandarius.}

'T'He Jay is a common but not abundant resident, breeding only in the roods, but generally diffused from autumn to spring, when it is a regular visitor, in small numbers, to some districts in which it does not breed.

In the autumn and winter of I 882, Jays were unusually abundant, a dozen or twenty together being noticed on several occasions in localities where the Jay is usually a scarce bird. It is probable that these were migrants from the European continent, as a flight of Jays passed over Heligoland in October of that year, and they were observed in unusual numbers in many parts of England (vide Zoologist, I 883).

\section{THE SWALLOW.}

Hirundo rustica.

The Swallow is an abundant summer visitor, arriving about the second week in April; in the north of the county the $I 7$ th is the average date on which I have noticed it during the last eleven years, but at Oxford it is a little earlier.

When the first broods are strong on the wing they flock 
together, and roost in osier-and reed-beds at the water side, often in very large numbers. On the Igth July, I 883 , I found a vast concourse, calculated at about fifteen hundred birds, roosting in the reeds at Clattercote Reservoir. During severe weather, after their arrival in spring, Swallows often perish from cold or starvation, as in $\mathbf{1} 886$, when many Swallows and Martins died after four days of N.N.E. wind and heavy cold rain. At the close of summer that year, the devastation effected could be clearly traced in the small numbers to be seen in the air after the second broods had flown, when in an ordinary year they should have swarmed.

A considerable portion of our Swallows depart at the end of September, but in varying numbers some remain until mid October and even later. Many instances of Swallows being seen in November are on record; thus, four were seen at Chinnor on the and in 1880 (B. D'O. Aplin), two at Bloxham Grove on the 16 th in the same year, one at Stanton Harcourt on the 18 th in 1877 (W. H. Warner), and individuals by Mr. J. Goatley on the Ioth, I2th, and $24^{\text {th }}$ in I 830 (Loudon's Magazine of Natural History, I831). At Weston-on-the-Green a Swallow was seen on the 28th February, I846, and three more on the following day (Zoologist, I 849, p. 2535). These can hardly have been early migrants, and must have wintered somewhere in England.

The arrival of the first Swallow, although accompanied, as it too often is, by bitter east winds or wet stormy weather, when flying scuds of rain and hail-perhaps snow-are alternated with fitful gleams of chilly sunshine, is eagerly looked for by many to whom, however ungenial the weather is at the time, the sight of the Swallow's form flitting over the surface of the river, or skimming quickly past us in the fields, speaks more forcibly than can any almanac of the near approach of the short English summer.

Again, in the still autumn days, though the sun may shine warm and bright, yet mellowed by the slight haze which fills 
the air, making the sunshine still more golden as it gleams on the yellow stubble and the hedge-maple, already turned, and flaming out gorgeously in its dress of red and gold ; still when

$$
\text { '... gathering swallows twitter in the skies,' }
$$

or congregate on the sloping roofs or the topmost twigs of some spreading walnut tree, we feel instinctively that it cannot be many weeks before the leaves will have fallen, the fields will be wet and sodden, the air cold and raw, that November will be come,-November with all its sportsman's joys, which nevertheless must always be to the majority of people our dreary season, from which the Swallows fly, as in spring they fly from the dust and heat of those southern lands, where they have passed the winter months, back to the fresh green island, their home.

\footnotetext{
'And something awoke in the slumbering heart of the alien birds in their African air,

\section{THE HOUSE MARTIN.}

\section{Cheliton urbica.}

The House Martin is an abundant summer visitor, arriving from the second to the last week in April, but sometimes not until May. Although the greater number have left by early October, a few are often seen up to the end of that month, and I have known young Martins (probably a third brood) still in the nest on the I 7 th. In November they have been observed by Mr. T. Goatley on the 18 th in 1830 (Loudon's Magazine of Natural History, I831, p. 431), and the 28th in 1837 (Zoologist, p. 2535). In December one was seen at Henley-on-Thames as late as the 18th in I880 (Zoologist, I 88I, p. 62). Martins always linger very late at Oxford. 
Gilbert White (who was at Oriel College, about the years I739 to I755) mentions seeing one on a very warm sumn morning flying about Christ Church quadrangle on the 2oth November, and Mr. W. Warde Fowler writes, 'In some years they may be seen on sunny days, even up to the end of the first week of November, hawking for flies about the meadowfront of Merton, probably the warmest spot in Oxford' ( $A$ Year with the Birds, p. 5).

\section{THE SAND MARTIN.}

Cotile riparia.

THE Sand Martin is a common summer visitor, arriving about mid April and learing in September. Breeding generally in colonies in the face of sand-pits, railway cuttings, and such like places, it is naturally somewhat local in its distribution in the nesting season, but on its arrival in spring, and again previous to its departure in autumn, it betakes itself to the neighbourhood of rivers and pools, where it may be seen skimming over the surface of the water far from its breeding haunts. Certain spots are annually affected by them, the young appearing there in July. Both the Swallow and Martin are partial to the vicinity of water, because insect life is more plentiful there than in drier situations, but the present species is even more so, and in the height of the breeding season, especially if the weather should be cold, many of our rivers and streams are frequented by these delicate little birds, which must have come from some considerable distance from their colonies for the sake of feeding over the surface of the water.

\section{THE SWIFT.}

Cypselus apus.

THe Swift is a summer migrant, arriving generally in the first or second week in May, and the bulk of them leaving us by the middle of August; in some seasons a few remain until 
the end of that month and even on into September, as in I 881, when they stayed in small numbers unusually late, and I saw one on the I I th September. In I 830, Mr. T. Goatley, writing of the late stay of Srallows that autumn, mentions a Swift seen on the 27th of that month. The earliest date for its arrival in spring that I am aware of is the 27th April, on which date $I$ saw one at Bodicote in 1885 .

As suitable nesting sites are not plentiful, many pairs often resort to such when found, forming little colonies, which return year after year, and many observers will be able to recall buildings which, on a quiet summer evening, would seem incomplete without the screaming Swifts dashing past the holes containing their sitting mates, whose faint answering scream may be heard under favourable circumstances. There is a little colony in the chapel quadrangle, at Trinity College. At Chinnor the Rev. B. D'Oyly Aplin noticed Swifts nesting under the low eaves of the thatched cottages.

Two nestling Srifts brought to me on the 28th July, I 880, although fledged, were unable to fly, or indeed to do more than push themselves about on their breasts, but after being crammed with a paste of exg, beef, and breadcrumbs until the 3 Ist, both flew away on the evening of that day.

[The Alpine Smift (Cyjsellus melba) is a rare visitor to this country. One was shot near Reading in August, I84I (Harting's IIandbook of British Bimls, p. I 26). In reply to my euquiries, Mr. J. E. Harting writes, 'With regard to the Alpine Swift killed near Reading, I am unable to say at this lapse of time (if indeed I ever knew) on which side of the river it was killed . . . Considering the insectivorous habits of the bird, and the usual abundance of insects near water, it is highly probable that it crossed and recrossed the river repeatedly in search of its natural food before it was shot' (in lit., 9th November, 1887).] 


\section{THE NIGHTJAR.}

Caprimulgus europaus.

Tire Nightjar is a summer visitor, but not at all a common one, and in the north of the county it is even rare. It breeds regularly on Shotover Hill, the keeper pointing out the spot to me in 1884 , and describing the grey-marbled eggs aceurately. Mr. Warner did not meet with the Nightjar in Oxon, but was informed by a friend that he had listened to it many times in Cokethorpe Park (in 7it., Jan. I6th, I 888), and Mrr. G. Arnatt has in his collection a pair, with two eggs, which were procured in Coggs Wood, near Witney, in May, 1882. In the north of the county I have no note of its having nested, and have seen the birds on one or two occasions only. The Nightjar is common in Bagley Wood, on the Berkshire side of the river, near Oxford (A. H. Cocks in lit.).

\section{THE CUCKOO.}

Cuculus canorus.

The Cuckoo is a common summer migrant, the numbers which visit us varying, however, in different years. The Cuckoo is usually silent, or broken-roiced, by the middle of June, but in the cold wet summer of 1879 , when everything was retarded, I heard it in full song on the 4 th July, and again in the somewhat similar season of 1888 on the 5 th of that month. The Messrs. Matthers mention that on the $23^{\text {rd }}$ and $24^{\text {th }}$ September, I 848 , a Cuckoo was heard singing in the early part of the morning. By the early part of August the old birds have left us, the youmg remaining a week or two later. The Messrs. Matthews indeed state that they will occasionally remain here as late as the end of October; but this is most unusual.

A letter addressed by MIr. E. TV. Harcourt to the Editors of the Ilis, and published in that periodical (1884, P. 467), contains an interesting account of an experiment carried out at Nuneham, which, as far as the single instance goes, proves 
that the graminivorous Linnet is incapable of rearing the young of the insectivorous Cuckoo, notwithstanding what has been stated by some naturalists to the contrary. A Cuckoo was observed by Mr. Harcourt to visit a Pied Wagtail's nest, built in the creepers on the balcony near the window of the chief drawing-room, and a Cuckoo's egg was subsequently found in the nest. Four days later the nest was deserted. The Cuckoo's egg was then put into the nest of a Limnet containing five fresh eggs, two of which were removed to make room for it. In thirteen days both the young Limnets and the Cuckoo were hatched. By the third day after, the former were all expelled from the nest, and, on being replaced, were expelled again. At the end of a week, however, the young Cuckoo died, apparently of starvation, and the old Linnets 'perched mournfully' on a rail, as if perplesed by the miscarriage of their matrimonial arrangements.' A young Greenfinch, of the same age as the former occupants, was then placed in the nest, and was successfully reared by the Linnets.

\section{THE HOOPOF.}

Upupa epops.

THe Hoopoe is a rare summer migrant to this country, and has occurred several times in Oxfordshire. First recorded as a British bird by $\mathbf{M e r r e t t}$ in 1667 , one of the earliest notices of it in this country is giren by Dr. Plot, who, ten years later, wrote- 'Other Birds there are here that are but rarely seen, yet breed in this Country, and are continually with us, and therefore to be numbered amongst those we eall perennial. Such are the $C_{l}^{\top}$ "lja, the Hoopoe, or Hooping-bird; whereof I saw one alive on Otmoor, and another was given to me for the Repository of the Bodleyan Library (killed somewhere about Cassenton) by one Mr. Painter, Alderman of Woodstock. A bird it is to admiration beautiful, being curiously deck'd with feathers of divers colours, and with a large crest on its head, as it is exquisitely engraven both by Dr. Charleton and 
Mr. Willughby; but like the Diabolus marinus, never appearing or being heard (as the vulgar will have it) till immediately before some approaching calamity.' (Natural IIistory of Oxfortshire, ch. vii. § 10.) Several instances of the Hoopoe breeding in England are upon record, and, if unmolested, there is little doubt but that some individuals would do so annually. It is interesting to find Plot stating so plainly that they bred with us in his day, although, as will be seen, he was mistaken in considering it a resident species. Near Eynsham a Hoopoe, which passed into Dr. Kirtland's collection, was shot in 1840 (Zoologist, p. 2598), and on the 25th September in the following year, as recorded by Mr. T. Goatley, one, which had been seen in the vicinity of Great Rollright for three or four days, was flushed from a wet furrow in a wheat stubble, and shot in an adjacent field. (Annals and Magazine of Natural History, vol. viii.) The remains of a fifth, which was picked up in a partly decomposed state on the railway near Heyford, about I 850 , came into my possession many years after, and Mr. A. H. Cocks has a note, dated 3 rd December, 1878 , of seeing a Hoopoe at Smith's, the bird-stuffer, in St. Ebbe's, which he was informed was killed at Headington Quarries in the previous summer (in lit.). Others have been procured at Claydon in I 864, at Eynsham about 1866 or 1867 (G. Armatt), and at Cropredy Lawn, the last named being shot in a turnip field (C. M. Prior). In more recent years, a Hoopoe was seen by a competent observer near Elsfield on the 26th April, I886 (A. H. Macpherson, MS.), and lastly a female, a very fine example, was shot at Waterperry on the 7 th May, I 888 .

\section{THE ROLLER.}

Coracias garrulus.

T'me Roller, which is a rare visitor to this country, has occurred in Oxon on one occasion only, namely, at Balscot, on the 29th May, I869. 


\section{THE KINGEISHER.}

Alcedo ispida.

Trie Kingfisher is resident in some numbers. No bird perhaps has greater difficulties attending its increase, and having regard to its comparative abundance under these cireumstances, there is no doubt that with favourable seasons and exemption from persecution, the Kingfisher would in a few years become a very common bird in most parts of Oxfordshire, which, with its many streams having high earthy banks suitable for the excavation of nesting-holes, presents many attractions for this beautiful species. Not only, however, is it shot or captured on every opportunity, but it also suffers greatly from severe winters. When our streams are bound in the grip of frost the Kingfisher is cut off entirely from its food supply, and must starve. The Rev. H. A. Macpherson believed that one Oxford bird-stuffer received hundreds in the winter of $1878-9$; and again after the great frost and snow-storm of January, I 88 I, when the Chervell was frozen and choked up with snow, numbers were found dead in the river after the ice had broken up. Although generally dropping upon its prey from some branch or root overhanging the water, the Kingfisher is occasionally observed to hover like a Kestrel. The following extract from my notebook relates to an early morning visit to Clattercote Reservoir. Whilst watching some birds on the opposite bank, a Kingfisher crossed the range of the glasses and splashed into the water, whence it rose with a small glistening fish; it settled on the wooden frame-work, now some feet above the surface of the water. After sitting motionless for a short time, it suddenly took wing, rose in the air, and remained poised on rapidly-beating wings for perhaps a quarter of a minute or twenty seconds, then dropped like a stone into the water, rose, and flew off. When thus poised the vivid beauty of the bird was past description; hanging in mid-air 
over the sparkling water, and illuminated by the brilliant sunlight, it shone like a living gem (August 4th, I884). The so-ealled small Kingfishers, distinguished in some parts of Oxfordshire by their shorter bills, are merely young birds of the year, in which the bill is not nearly so long as in the adults.

\section{THE GREEN WOODPECKER.}

Gecinus viridis.

Tre Green Woodpecker is a resident, and in some parts of the county is not at all uncommon. About Oxford it is tolerably plentiful (H. A. Macpherson, MS.), and in Nuneham Park, where old timber abounds, it is particularly numerous ; but in the neighbourhood of Standlake, Mr. Warner does not remember having heard its cry more than once or twice during his eight year's' residence in that village. In the north of the county it is far from uncommon, especially in and about the various parks and park-like grounds. At Kingham, Mr. Fowler notes it as resident and apparently commonest in autumn; this is the case in other parts of the county, and is doubtless owing to the fact that it is more generally diffused at that season, and more observed. Shy and unobtrusive in the breeding season, and naturally to a certain extent restricted to the more wooded situations, retiring into the woods themselves in those districts which afford them, it wanders freely in autumn and winter in search of food, and its laughing cry is then a not at all uncommon sound.

The Green Woodpecker obtains a large proportion of its food upon the ground, and may be observed in grass-fields, often at a little distance from trees, and especially in those scattered over with ant-hills, into which the Woodpecker thrusts its beak and face up to the eyes in search of the insects. It is certainly their habit to feed thus in winter, and not in summer only as stated by some writers; of the number of specimens I have handled in the former season 
I have rarely seen one which had not some earth clinging to its beak. For this reason they suffer greatly when snow lies deep on the ground, and many succumb in prolonged hard weather, as for instance in January, I 88I, when a great many were bronght to the stuffers, and in the last ten days of 1886 , when no less than fifteen were taken to one man alone. The larger number of these last had been shot, for inconspicuous as the Green Woodpecker is under ordinary circumstances, it is otherwise when snow covers the ground, and hunger has rendered them less shy than is their wont. The presence of a hole oceupied by Woodpeckers is often discovered from the heap of chips of freshly hewn wood, strewn round the foot of the tree, catching the eye of the passer-by.

All three species of Woodpecker are known in Oxfordshire by the name 'Hickle,' a corruption of 'Hickwall,' which is used by Willughby in the seventeenth century.

\section{THE GREATER SPOTTED WOODPECKER.}

Dendrocopus major:

Tine Greater Spotted, or Pied, Woodpecker is a scaree resident, found most commonly in our wooded parks. The Messrs. Matthews state that its nest has been found near Oxford, and the Rev. H. A. Macpherson informs me he has seen it at Shotover. In Nuneham Park it is resident in small numbers, Mr. R.S. Batson informing me that he sees perhaps one in every month. On the 26th May, r888, Mr. Batson discovered a hole in the trunk of an oak in the Black Wood in which a pair of Pied Woodpeckers were nesting, and an hour or two later I visited the spot with him. Mr. H. Gale having ascended the tree, a piece of bark was carefully taken out, and sufficient wood cut out with a chisel to enable him to reach the bottom of the hole. Unfortunately one egg only was found to be deposited, and, as it was desirable to obtain a pair for the Park collection, we decided to try and induce the hen bird to return to the hole. The egg was therefore put 
back, the abstracted wood made good with some clay, and the bark neatly replaced and nailed on. Te then lay down in the wood to await the return of the old birds, which could be heard tapping on the neighbouring trees. After a short interval the hen bird came to the tree, but detecting a slight movement on our part (consequent upon the attacks of swarms of most rapacious midges), darted away again. A little later she again settled on the tree close to the hole, but appeared to see that something was wrong and flew off. The male afterwards arrived and hammered away for a fer minutes on a partly rotten bough at the top of the tree, but as the hen did not return we left the place. On revisiting the spot the next day we failed to detect the birds, which, however, were heard 'jarring' in the vicinity. Nevertheless the hen bird must have returned and laid on that day, for, on the hole being examined on the zoth, five eggs were found to be deposited, and the male bird was captured in the hole, showing that incubation had commenced. This incident is interesting, because it illustrates the extreme attachment of Woodpeckers to the nesting-hole they have selected. Two more nests, containing young birds, were found in the park in July of the same year, Mr. Gale's attention being called to them by the chattering of the young birds inside the hole. Mr. Batson, in communicating the discovery, remarks-' this is incessant, and varies somewhat with the position of the young birds, as they occasionally come to the mouth of the hole and then retire well inside, but can still be distinctly heard' (in lit.). In Broughton Park the Pied Woodpecker probably breeds, as I have seen several specimens both in the adult and immature plumage which had been procured there. In Mollington Wood the Rev. H. Holbech eaptured a young bird, hardly able to fly, in June, I882, and Mr. W. Wr. Fowler observed one in Churchill Heath Wood, near Kingham, in May, 1888, where they are not uncommonly seen by the keeper. In autumm and winter it is more generally diffused, and a year seldom passes 
without several specimens being sent to the bird-stuffers; at the latter season I have twice seen it in the wooded fields of Bloxham Grove.

That an immigration of this species to the eastern side of England from some part of Europe occasionally takes place in autumn is well known, and a male procured near Bodicote on the 3 rd December, I887, which had the under parts of a deeper tint than usual, and exhibited traces of red markings on the breast, was probably of continental origin (cf. Yarrell's History of British Birls, vol. ii. p. 475).

\section{THE LESSER SPOTTMD WOODPECKER.}

Dendrocopus minor:

The Lesser Spotted, or Barred, Woodpecker is a resident, and is not at all uncommon, but, from its diminutive size, and its habit of frequenting the upper branches of tall forest trees, is senerally overlooked. In such situations, when climbing on the upper side of a branch, it easily escapes the notice of an observer from below, who, unless attracted by the sound of its tapping, its rarely uttered cry, or the curious noise to be refered to presently, would probably pass it by. Even when its presence is detected by any of these signs, it is no easy matter to get a clear sight of the bird. Its distribution over the county appears to be subject only to the presence of a sufficiency of timber trees, although its requirements in this way are not so extensive as those of its larger relative. The Barred Woodpecker often enters villages, even in summer, and in June, $\mathbf{1 8 8 0}$, a shot fired at some Sparrows in a row of scarlet-rumner bean sticks, in a garden at Bodicote, resulted in the death of an immature bird of this species. Mr. E. W. Harcourt informs me that it has bred recently in the park at Nuneham, and it probably does so annually at Broughton, Wroxton, Great Tew, Bloxham Grove, and in many other localities. In winter it is widely distributed wherever hedgerow timber is found. 
The curious 'jarring' note produced by this bird in spring was long agro noticed by Plot, who writes, 'A little Bird, sometimes seen, but oftner heard in the Park at Woodstock, from the noise that it makes commonly called the Wood-cracker: Described to me (for I had not the happiness to see it) to be about the bigness of a Sparrow, with a blue back and a reddish breast, a wide mouth and a long bill, which it puts into a crack or splinter of a rotten bough of a Tree, and makes a noise as if it were rending assunder, with that violence, that the noise may be heard at least twelve score yards, some have ventured to say a mile from the place.' (Natural History of Oxforlshire, p. 175.) The bird he describes was evidently the Nuthatch, and according to the editor of 'Yarrell' (vol. II, p. 477), Plot seems to have been the first to promulgate the mistaken opinion as to the origin of the noise. In the second edition (I705) of his work, however, he inserts the note, 'Quaere, whether this be the Picus Martius of Mr. Ray mentioned in the Phil. Trans. pp. 1043, 1044.' Onithologists do not appear to be entirely satisfied as to the manner in which the jarring is effected, but on the only occasion on which I have had an opportunity of clearly observing the bird while in the act of producing the noise, it certainly seemed to be the result of a succession of exceedingly quick taps on the branch; when the sound was heard, the bird's head moved with inconceivable rapidity, and the noise, which could be heard at a considerable distance, was louder when the bird operated on some boughs than on others.

\section{THE WRYNECK.}

\section{Iynx torquilla.}

THE Wryneck is a summer visitor, arriving at the end of March, or early in April, and generally making its presence known by its resonant cry, que que que, repeated many times in succession. It is not at all a common bird with us, and there is some evidence to show that it has become rarer of 
late years. The Rev. Murray A. Mathew informs me that it was very common about Oxford in his time ( $1855-60$ ), and that he took its nest close to Magdalen Bridge (in lit., June I 5 th, 1886), but the Rer. H. A. Macpherson (1877-82) notes it as by no means plentiful in that neighbourhood. In the north of the county, in my own experience, it is certainly less often heard than was the case some years ago. Although accurately described by an old keeper to $\mathrm{Mr}$. W. Warde Fowler (A Year with the Birls, p. I04), he has failed to detect the Wryneck about Kingham, but I easually observed one by the roadside near Enstone in June, I882. On the other hand, it appears to be not uncommon at Standlake, where it is a regular visitor, appearing about the second week in April, and being locally known by a name often bestorved upon it in various parts of the country, namely, 'Cuckoo's mate' (Wamer, MLS.). At Cuddesdon also, as Mr. H. Gale informs me, it is tolerably common.

\section{THE RING DOVE.}

\section{Columba palumbus.}

Tue Ring Dove, or Wroodpigeon, is a common and slightly increasing resident, breeding alike in woods and spimneys, and in hedgerow timber and isolated thorn-bushes, at various elevations; a nest on Hanwell Heath was placed in a low hawthorn not more than three feet from the ground.

In winter considerable migratory flocks occur; two such on the 30 th January, 1886, winging their way to roost in the woods at Aynho in. Northamptonshire, must have numbered two hundred birds at least in each. These flocks are sometimes scen well on into spring. As late as the I8th April, in I 887, I observed at Hook Norton a flock of fifty, which were doubtless passing migrants; our home birds being paired before that date, and eggs having been found in some years as early as the last week in the previous month.

Varieties of the Ring Dove are not common. In February, 
I 886, Mr. A. H. Macpherson saw, among a flock near Oxford, one which appeared nearly pure white, and on the 26th October, in the same year, a very pretty variety (now in MLr. J. Whitaker's collection at Rainworth Lodge, near Mansfield) was shot near Banbury and brought to me. In this specimen the mantle and wings are dove-coloured, mottled with a little white, tail brownish, and the lower part of the back a delicate lavender; otherwise the plumage is normal and the metallic sheen on the neck is very fine.

\section{THE STOCK DOVE.}

Columba wnas.

The Stock Dove is a resident species, locally common, breeding numerously in the wooded parks at Blenheim, Nuneham (where it is exceptionally abundant), Sarsden, Broughton, etc., and freely also in all the well-timbered parts of the county. It is rather a familiar species in the breeding season, frequently nesting in hollows in the ormamental timber which stands round so many of our country houses; a few pairs inhabit the gardens of St. John's and Trinity Colleges in Oxford, breeding in the former, while others find a home in the old elms round Kingham Church (W. W. Fowler), and numerous other similar localities could be cited. With us the Stock Dove usually deposits its eggs in hollows in timber trees, and in the heads of pollard ashes and willows, going to nest early in the spring.

Although often seen in winter, even in severe weather, it is probable that the larger number of these birds leave us at that season.

The range of the Stock Dore in England has become more extensive of late years, and its numbers have increased considerably in many parts of the country; to some extent this appears to have been the ease in Oxfordshire. The Messrs. Matthews, writing in 1849 , say that it was 'occasionally seen in this neighbourhood at all seasons, and its nest has sometimes 
been found.' Mr. T. Goatley informed them that it bred at that time in holes of trees in Heythrop Park, and was resident. (Zoologist, p. 2432.)

On a cold frosty day in October, I 887 , when fishing in the Swere at Barford just before sundown, a Stock Dove flew close past me and alighted on the water, which was about two feet deep at that spot, the banks being quite steep. It settled with outspread wings, drank, and then, rising without difficulty, flew off. It would have been easy for the bird to have gone to one of the several shallow eattle waterings in the meadow.

Early in September, I 886, two varieties of the Stock Dove were procured on Shotover Hill. One, a very pretty bird, mottled with cream-colour, is now in Mr. J. Whitaker's noted collection, a coloured plate of it being given in Mr. S. L. Mosley's work on British Birds; the other had nothing abnormal about it except the primaries and rectrices, which were of a rusty brown. It is probable that these two birds were hatched together.

\section{THE ROCK DOVE.}

Columba livia.

Tue Rock Dove has been included in the list of Oxfordshire birds as an occisional visitor. The Messrs. Mathews wrote'Sometimes seen in this neighbourhood during the autumn, but it is a very uncertain visitor' (Zoologist, p. 2598). Concerning this note the Rev. A. Matthews informs me that although he never shot one, he had seen specimens in the late Mr. Forrest's shop (in lit.). The Rock Dove has been recorded as breeding in inland situations in several instances; but a suspicion that they are merely dovecot pigeons which have reverted to a feral state always attaches to these individuals, and to such those that have oceurred in Oxon may possibly be referred. The Rock Dove is included in the Ilistory of Banbury list, as an 'oceasional visitor,' on the authority of Busby, a former keeper at Broughton, but as keepers often 
call the Stock Dove the 'Rockier,' it is probable that a confusion of the two species arose.

\section{THE TURTLE DOVE.}

Turtur communis.

Tre Turtle Dove is a regular summer visitor, breeding commonly, but not very numerously, in woods and plantations, and in tall hedgerows, all over the county. Arriving about the second week in May, it is rarely seen after the early part of September, when they are sometimes met with by sportsmen in the stubbles and turnip-fields; in 1879 two were seen, and one shot, in a turnip-field at Adderbury on Michaelmas day.

For several years a pair of Turtle Doves nested in the top of a large old iry-clad weymouth pine in my brother's garden at Bodicote.

\section{PALLAS'S SAND-GROUSE.}

Sym.haptes paradoxus.

The Sand-Grouse is a native of the Asiatic steppes, where it rears two, and sometimes three, broods in the season, and increases very rapidly. It is liable to sudden movements in large flocks ( $f$. Yarrell), and has visited Europe, spreading westward across the continent to the shores of Great Britain, on several occasions. The first memorable invasion of Lingland by this species occurred in $186_{3}$, when a great number were killed in this country, but, as far as I know, none were seen in Oxfordshire in that year. In the spring of 1888 , however, another, and still larger, immigration took place, and SandGrouse were observed in several parts of this county.

On the 2oth May, some Sand-Grouse were seen near Bensington, as recorded by MIr. W. Nerwton, jun. (Field, 26th May), who has kindly furnished me with the following particulars. They first made their appearance on a piece of ground drilled with swede turnips (which were not then 
showing above ground) on the top of Harcourt Hill, near Swyncombe, where they were seen by Mr. Nervton, in flocks of from five to six- or seven-and-twenty, during the months of May and June and as late as the first week in July. The ground they frequented was very bare and of a dry sandy nature, and the birds were extremely wary. A male and female were secured on the and May; the female contained a number of eggs, some of which, in the opinion of Mr. J. Gardner, of Oxford Street, would have been laid in a few days; but no eggrs are known to have been actually deposited in this locality.

Mr. W. Padbury King, writing from Lower Heyford to the Stamlard for the 5th September, stated that the SandGrouse had been there since early spring. The first that were noticed were a flock of fourteen which were seen by Mr. King's shepherds, but he himself did not see any until the date of his letter, the 3 rd September. He writes-'I saw them fly swiftly over my head, with a sharp continual ery like tack, tack, tack. They were a mottled colour of bay and grey, with marvellously pointed wings.' In reply to my enquiries, Mr. King kindly wrote me word that they were first seen on the 12 th May, and frequented the light stonebrash land on the higher ground, taking long flights over the Cherwell valley (where they had never been seen to settle) to the ploughed fields at Rousham, also on the stone-brash. In September they were found in a turnip field. On the 2.5th October, Mr. King wrote to me that the Sand-Grouse had not been seen for a fortnight, and had not bred there, confirming the author's conviction that these desert-loving birds would gradually disappear from this county at the approach of winter, being unfitted to withstand the cold combined with the damp of our autumn and winter climate.

On the high ground near Fyficld, to the north of Burford, a flock of nine were seen early in July, by an old gamekeeper, who got within twenty yards of them, and described them as 
dirty-brown birds, making a curious noise, and looking as if they had webbed feet-an appearance which their curiouslyformed feet would be very likely to present to an olserver; another flock of five were seen by a farmer in the same neighbourhood (W. W. Fowler in lit.).

\section{THE BLACK GROUSE.}

\section{Tetrao tetrix.}

THE Black Grouse has occurred as a casual wanderer. In October, 1836 , a Grey-hen was shot near Forest Hill, but the MIessis. Matthews, who recorded it, thought it not improbable it might have escaped from some aviary, although its plumage showed no appearance which would lead to such a conclusion (Zoologist, p. 2598). On the end May, I880, I examined at a bird-stuffer's in Banbury a fine Blackcock, freshly stuffed, which was said to have been shot at Tackley, near Woodstock, three weeks previously; its owner, in face of the flagrant infringement of the Game laws, would not allow his name to be disclosed, and I was unable to gain any further particulars of the occurrence.

Examples, descendants of the race of Blackgame reintroduced into Wolmar Forest, Hants, appear to have strayed into the heathy portions of Berkshire; and in Surrey, where they were also introduced, they have been found about Leith IIill and Guildford (Yarrell); it is also found very sparingly in Wiltshire. The examples procured in Oxfordshire may have wandered from any one of these localities.

\section{THE PHEASANT.}

Phasianus colchicus.

The Pheasant was introduced into England at some very remote period, probably by the Romans, and had become naturalized and sufficiently abundant to be used as an article of food before the times of the Norman conquest (vile Yarrell's History of British Birls). 
The nature of this county in most parts is well adapted to the requirements of the Pheasant, and a certain number maintain themselves in an independent condition, many a 'nide' being hatched out in the hedgerows far from large covers, and in localities where no especial protection is afforded them; of the large numbers reared and maintained under more or less artificial conditions on some well-preserved estates it is unnecessary to say anything.

The typical $P$. colchicus, the original stock brought into the country, is now rarely found, having been largely erossed with the Chinese Ring-necked Pheasant, P. torquatus, the cock of which possesses a white ring round the neck, and by far the larger number of birds now killed in the county have this mark more or less developed.

The variety of the Pheasant in which the whole of the body below the neck is of a pale buff or stone-colour with dark markings, and known as the 'Bohemian' Pheasant, is occasionally killed, as also are pied birds, while pure white examples, both cocks and hens, are sometimes met with. This last variety has long been known in Oxfordshire, for Plot mentioned, in 1677 , 'a sort of white and yyed Pheasants, kept by the Right Honourable James Lord Norreys, of Ricot.'

\section{THE COMMON PARTRIDGE.}

Perdix cinerea.

The Common, or Grey, Partridge is such a well-known resident in this highly-cultivated district that little need be said as to its distribution, but, as a proof of how eminently adapted our county is to its requirements, it may be stated that, in the north of the county, where, except from diurnal poachers, the Partridge has but little protection from its numerous enemies, being exposed to the unchecked ravages of innumerable exg-stealing Crows and Magpies, as many as twenty or thirty brace can be bagged in a day. With the 
disappearance of the long wheat stubbles the difficulty of killing Partridges (in a country where 'driving' is impracticable) was greatly increased, and sportsmen generally have noticed that the birds have become much wilder and more difficult of approach of late years, flying also, when put up, to a greater distance before alighting. A considerable change in this respect has certainly taken place even within the last ten or fifteen years, turnip fields often failing now to give the close shots which were once assured, and, save in exceptional cases, it is in standing corn alone that the birds will lie well.

The variety of the Partridge in which the chestnut of the 'horse-shoe' mark on the breast is replaced by white, which is not very uncommon in some parts of England, has only once come under my notice in Oxfordshire, namely, in September, I 888, when I saw one shot at Barford, but MIr. J. Hyde tells me he has killed one or two at Bloxham. In I885, I shot a remarkably fine example within a quarter of a mile of the county boundary, in Northamptonshire, and had noticed for two or three years previously that the birds on a farm at Adderbury, not far from where the above bird was killed, had a good deal of white mixed with the ordinary chestnut. The proportion of white appeared to be on the increase each year, and some birds killed in that autumn showed nearly an even amount of chestnut and white. I have since seen other similar examples shot near Bloxham, the variety being evidently on the increase.

Abnormal varieties of the Partridge are uncommon, but a pied specimen which was shot at Standlake some years ago is still preserved there, and another nearly white bird was seen at the same place in September, I883 (W. H. Warner, MS.).

\section{THE RED-LEGGED PARTRIDGE.}

Caccabis rufa.

The Red-legged, or French, Partridge is stated by Daniel; in his Rural Sports, to have been turned down at Windsor in 
the time of Charles II, but they were supposed to have mostly perished a few years afterwards. In I770, however, it was introduced in larger numbers into Suffolk, whence, spreading south and west, it has come to Oxon by way of Buckinghamshire.

Its first appearance in this county seems to have been in the Chiltern district, where, as stated by the Messrs. Mattherrs, a pair were killed on the hills near Stokenchurch in 1835 , and on the 21st September, I848, a covey of six were found in the same locality by Mr. Willoughby Beauchamp. (Zoologist, p. 2598.) In this locality the Rev. B. D'O. Aplin found it common in 1879 , frequenting the rough ground at the top of the hills, and being often found in the tall ling, from which I flushed one in June, I 880, when investigating with him the natural history of the district. About Thame, however, it continued rare, or unknomin, for many years subsequent to 1848 .

In the neighbourhond of Oxford no information as to the date of its first appearance has been available, but at the present day it is not uncommon, breeding, among other places, at Nuncham and Forest Hill, some numbers being annually brought into Oxford Market.

Passing up the east side of the county, where it is now well established, the Red-legged Partridge continued rare in the northern division until comparatively recent years. My late father, whose shooting days extended over a period of more than forty years, from about 1836 , and who during that time shot in many parts of the north of the county, among other places at Heythrop for ten or twelve years, only shot one of these birds until the last year or two of his shooting. This was at Heythrop prior to $\mathbf{x} 860$, and he always considered it had been mischievously introduced (a supposition rendered highly probable from the fact that these birds are hardly established in that district even now), 'Frenchmen' being held in great disfavour in those days. At Arncot, near Bicester, 
and near Thame in the east of the county, he never met with it. It was about 1879 that the Red-legged Partridge was first noticed as becoming common in North Oxon, since which date they have increased rather rapidly, being now very generally met with during the season, and seen in steadily increasing numbers hanging in the game-dealers' shops in Banbury.

Into the north-west of the county, about Chipping Norton, it does not appear to have penetrated naturally. Mr. W. Warde Fowler informed me in 1887 , that Mr. E. D. Lockwood had shot in the neighbourhood of Kingham on and off for the last thirty years, he thought, without finding one, and they were quite mknown to old keeper Cook. In 1868 , however, they were introduced by the Earl of Ducie at Sarsden, where they seem to have thriven, as shown by the following particulars kindly communicated to Mr. Fowler by Mr. W. C. Carnegie, Lord Ducie's agent. From fifty egg's the keeper reared thirty-eight birds, which were turned down, and, from his game book, it appears that during sixteen years, I 87 I to I 886 inclusive, sixty-eight birds were shot, giving an average of four and a quarter birds per year; none, however, were shot in 1878,1879 , or 1883 , while in 1885 nineteen were bagged. From this it appears that they are now thoroughly established, and a pair which Mr. Forwler and I saw in March, 1888, in a rough grass-field at Idbury, were doubtless descendants of the Sarsden birds.

At Shipton-under-Wychwood, I heard in I 888 that they were not uncommon.

In the neighbourhood of Stonesfield, where the limestone slabs known as Stonesfield slates have been quarried for ages, the Red-legged Partridge finds a congenial home, and is met with in some abundance, as shown by the following extract from an interesting letter written, in March, 1888 , by Mr. John Worley to the Rev. J. W. B. Bell:- They seem to enjoy very uneven ground where there is a quantity of stones, and a whole covey will often settle on a wall and run 
along the top of it. I once killed a leash at a double shot out of a covey rising from a large heap of slate chippings at Fawler, and I have seen more there than anywhere else, entirely in my opinion owing to the quantity of stony, uneven ground caused by the digging of slates.'

At Burford, I was informed in I 888 that the Red-legged Partridge was often killed in the neighbourhood, but it is still discouraged there, the eggrs being destroyed when found.

At Brize Norton, Mr. John Worley reports them not uncommon, mentioning three coveys on his own land in 1887 (in lit. to Rev. J. W. B. Bell).

About Bampton, from evidence adduced by the Rev. J. II. B. Bell in 1888 , it is rare, though a specimen was killed as long ago as twenty years previously, and a covey was found at Aston some ten years since.

From information olstained by Mr. W. H. Wrarner it seems to be still quite rare in the neighbourhood of Standlake, but a singie one was shot in September, 1887; others have been killed at an earlier date at Stanton Harcourt.

Such, so far as I have been able to discover, is the present distribution of the Red-legged Partridge in Oxfordshire, but there is little doubt but that before many years have clapsed it will become numerous in all parts of the county, although naturally more abundant in those districts best suited to its habits.

The Red-legged Partridge is more commonly found in rough pastures, on grassy hill-sides interspersed with patches of gorse, jumiper, or ling, and at the edges of thin woods, than on the corn lands; to this circumstance may in part be attributed its abundance in the Chilterns, and also to some extent its delay in pushing on into the north-western part of the county, where the bleak, open corn-fields presented but few attractions to this handsome bird. Althongh usually placed upon the ground, the nest has in several instances in Oxfordshire been found on the top of a corn- or straw-rick. 


\section{THE COMMON QUAIL.}

Cotumix communis.

Tre Quail is a summer visitor, but several instances, to be enumerated presently, of its occurrence during the winter are upon record. Always irregular in its appearance, at the present day it visits us in fewer numbers and more intermittently than was formerly the case-a circumstance noticed by ornithologists in many parts of England. Old keeper Cook told me that in his young days he has seen four or five 'beries' in a day on Kingham open fields, where they ar' now rare, and many sportsmen speak of the scarcity of these lirds as compared with former years. A few pairs doubtless still come to us annually, and breed in various parts of the county. Mr. Warner writes of Standlake, 'a pair or' two of these birds occur in this neighbourhood most seasons' (IIS. notes), and the late Rev. T. W. Falcon informed me that Quails, in some seasous, were very common about Charlton-onOtmoor (in lit.). In the north of the county I have heard of a few nests being mown out at various times, but, save in exceptional years, it is uncommon. Mr. T. D. Denchfield tells me he has met with them in one or two years recently at Barford and Bloxham. In certain seasons, however, a considerable immigration of Quails takes place. The year 1870 appears to have been a noted Quail season, and several examples were preserved by the bird-stuffers. After this date no visitation of this species in any numbers occurred for fifteen years; and, although we met with a single bird at Bloxham in September, 1878 , in which parish one was shot in the October following (Zoologist, I879, p. I29), and another was procured at Brize Norton in September, I 880 (G. Arnatt, $M S_{\text {. }}$ ), yet when writing in the spring of $\mathrm{I} 885 \mathrm{I}$ could state that I had seen no eggs taken in the county during the last ten years. The year I 885 was, howerer, a great Quail season, though the birds do not seem to have been noticed in the 
spring; one which I heard calling in a clover field at Great Bourton on several evenings in May, was the only one I had notice of. In September that year we flushed two from some standing oats, in the same field where we saw the single bird seven years previously, and others were subsequently found at Adderbury, Barford, Sibford, Hook Norton, 'Edward's Field' (Standlake), Burford, Cowley, and at one or two spots on the Northamptonshire boundary ; about thirty or forty being killed, and others seen. In a letter from the Earl of Ducie to Lord Walsingham, communicated by the latter to the Ilis (I886, p. IOI), it is stated that the keeper, early in September, put up at least thirty in one day on the Sarsden estate (where there were generally two or three bevies in the season), and that Quails were killed in unusual numbers that year in the district between Chipping Norton and Oxford.

The Quail arrives here in May, the $5^{\text {th }}$ being the earliest date of which I have notice, and remains sometimes until October, its stay being affected by the state of the harvest; the partiality of this species to standing corn inducing it to linger in late seasons. From the difficulty of flushing Quails they no doubt often escape observation, and even where put up they are occasionally mistaken for 'squeaker' Partridges, and allowed to escape, their rapid and direct flight being unnoticed until the bird is out of range.

Two instances of the Quail having been found in Oxfordshire during the winter were communicated by Mr. Goatley to the Messrs. Matthews, who also mention occurrences on the Ioth November, I 846 , and the 9th December, I 848 (Zoologist, p. 2535). A clutch of nine fresh eggs was taken in September, I886, near Standlake, not far from Witney, whence a bird, shot in severe weather on the 15 th of the following January, was sent up to Oxford Market; another was shot in that neighbourhood about the end of the same month, as I am informed by Mr. A. H. Macpherson, who, near Nuneham, saw two Quails, which passed close to him, in severe weather, on 
the 2nd February, I888. A late Quail's nest, containing nine slightly addled eggs, was found at Deddington in the first week of September, I 888 .

That the Quail was formerly well known in this county is shown by the fact that it is locally called, both in North Oxon and on Otmoor, by the onomatopoetic name of 'Twit-medick'; but in the curious call-note the stress is laid on the first syllable, which is uttered slowly, the last two syllables following quickly after a slight pause. 'Twit-mı̌ddı̌ck' would therefore express the sound better.

\section{THE ANDALUSIAN HEMIPODE.}

\section{Turnix syluatica.}

The Andalusian Hemipode is an accidental visitor. In the Annals of Natural History (vol. xiv, p. 459), appeared the following letter, addressed to the editors:-

\section{Gentlemen, -}

I have recently received a bird which appears to me to be new to this country; it is a Quail, having no back toe, and is not mentioned, I believe, in any work on British Ornithology to which I have access; but in Dr. Latham's 'General History' it is described as the Perdix Gibraltarica, with which my specimen appears to agree. The bird was shot by the gamekeeper on the Cornwell estate in this county, about three miles from hence, and has been kindly presented to me. It was found in a field of barley, of which grain, by-the-bye, hundreds of acres are still standing, with no prospect of being harvested in a proper state. Before I proceeded to preserve the bird I took the measure of its various parts, the colour of its eyes, bill, and feet, its weight, etc., after which I found its description in the work before alluded to. It was shot on the 29th of October last, since which time another has been killed near the same spot by the same person, but its head was shot off, and otherwise so mutilated as to be unfit for preservation : this might probably complete the pair, mine being the male bird. It had in its gizzard two or three husks of barley, several small seeds similar to charlock, some particles of gravel, and was very fat. It was considerably injured by the shot, but I have set it up in the best manner I could, and consider it a valuable addition to my small 
collection of British Birds. Should this prove to be the only instance of the capture of the bird in Britain, I shall feel glad in having saved it from oblivion.

I am, Gentlemen,

Your obedient Serrant,

Thos, Goatlex.

Chipping Norton, Oxon.

Nov. II, 1844 .

[The bird in question is the Hemipodius tachidromus of Temminck, which is figured in Mr. Gould's 'Birds of Europe,' vol. iv, plate 264. Mr. Gould, to whom we have shown Mr. Goatley's letter, considers this one of the most interesting additions to the British Fauna that has occurred for many years.-En.]

This specimen, then in the collection of the Rev. H. Roundell of Fringford, was figured by the Messis. Matthews in the Zoulogist for 1849 , and it was also drawn and engraved for Yarrell's Ilistory of British Birls. Mr. Edward Newman, to whom Mr. Goatley sent the bird, accompanied by a photograph, had the pleasure of showing both to the London ornithologists, and published full particulars of the specimen in the Zoologist for 1845 , p. 989.

Upon the evidence of $\mathrm{Mr}$. Goatley's letter this species was included among the British Fama, and, with the exception of another said to have been taken in Yorkshire in 1865 , it has never been procured in Great Britain since.

The Andalusian Hemipode inhabits parts of southern Portugal and Spain, Sicily, and, in North Africa, parts of Moroce, Algeria, Tunis, and Tripoli, as far as the confines of Egypt. It is very local in its distribution, and has never been proved to wander to any extent. (Yarrell, ed. H. Saunders.)

\section{THE IAND RAIL.}

Crex pratensis.

The Land Rail, or Corn Crake, is a regular summer visitor, and although the numbers which arrive vary somewhat in different years, is commonly distributed throughout the county, being perhaps less plentiful in the bare arable parts 
than in the river valleys; Mr. Fowler reports it as not abundant in the neighbourhood of Kingham. Arrivingabout the end of April, sometimes before the herbage is sufficiently advanced to afford it cover, it is usually the middle of May before it makes its presence generally known by its wellknown ery, best heard in the stillness of an early summer night, when I have sometimes listened to four or five 'craking' at the same time.

An early mention of the Corn Crake in Oxfordshire occurs in the Pinax Rerum. Naturatim Britannicamm (1667), of Christopher Merrett, one of the earliest faunal works relating to Great Britain, wherein the author calls it the 'Daker-hen,' and believes he heard it at Theatley, four miles from Oxford.

Although best known as a summer resident, and to sportsmen in the early part of the shooting season, the Land Rail has several times been met with in mil-winter. Mr. Roundell informed the Messrs. Mattlews that in the winter of $\mathrm{I} 846-7$, during a severe frost, with snow on the ground, a Land Rail was constantly seen feeding with fowls in a farm-yard, in the parish of Fringford; the same authors also mention occurrences in the parish of Weston-on-the-Green in December, I841, and 1848 , and at Fringford in January, I 844. (Zootogist, p. 2535.) The Rev. H. A. Nacpherson has knomn it to occur at Oxford in the early winter of 1882 (MS. notes); Mr. A. H. Macpherson purchased a Land Rail in Oxford Market, which had been sent up from Standlake, on December Ist, I887, while two or three others, procured during the winter months, in the north of the county, have come under my own notice.

\section{THE SPOTTED CRAKE.}

Poizana manuetta.

The Spotted Crake is a spring and autumn migrant, oceurring in March, and again occasionally in August, but more commonly in September and October. The Ioth March, 
on which day, in 1887 , an example struck the telegraph wires at Oxford, and came into the possession of $\mathrm{Mr}$. A. H. Macpherson, is the earliest date for its arrival in spring of which I am aware; another met the same fate near Banbury on the I 4 th of that month in I88I. In autumn Spotted Crakes are occasionally met with in some numbers; the Hon. T. L. Powys noticed them unusually abundant in 1853 , mentioning six or seven in Oxford market in September and October. (Zuoloyist, 1854.) Although often oceurring up to the middle of October, I have no note of its having been obtained later than the Igth of that month.

There is some reason to believe that the Spotted Crake may breed in Oxfordshire, the occurrence of immature examples in August rendering the supposition more probable; among other instances, an entry in Mr. Beesley's note-book, relating to one shot on the 19th of that month in 1849 , may be cited. From its skulking habits it rould easily escape observation in the height of summer.

The Spotted Crake has quite a penchant for immolating itself on the telegraph wires, a large proportion of the examples procured having been killed in this manner.

\section{THE LITTLE CRAKE.}

Porzana parra.

Tre Little Crake is a rare visitor, on migration, to England, having perhaps remained to breed in some instances. Mr. C. M. Prior was informed that a specimen was shot at Cropredy. (Banbury Guardian.)

\section{THE WATER RAIL.}

Rallus aquaticus.

The Water Rail is a resident species, generally distributed in fair numbers along the banks of our streams and sheets of water, which have a sufficient growth of rushes and tall water-plants to afford it shelter. Although entered here as 
a resident, I am only aware of one instance of the nest of this species having been actually discovered in the county. The record of this is contained in a note in the Zoologist, dated September IIth, I863, by Mr. C. Stubbs, of Henley, who writes, ' $\mathrm{I}$ this year found the nest of the Water Rail, with eggs ; it was built amongst the sedge and composed of the dead leaves of the sedge' (p. 868I). In I879, however, I examined a young bird in black down, one of a brood captured in the Cherwell below Banbury, which was believed to be of this species. In summer indeed the Water Rail is seldom seen, but, from the notes of its occurrence which I have by me, it can hardly be considered as otherwise than a resident, and the Rev. A. Matthews informs me he considered it as such in the neighbourhood of Weston-on-theGreen, where it was very common (in lit.). A considerable number of Water Rails are, however, killed by flying against the telegraph wires, presumably when on migration; I lnow of an instance of one being killed by coming in contact with a railway truck in motion.

Severe weather, when it is frozen out of its usual haunts, is the time when the Water Rail is most often seen, for it is one of the shyest of birds, and, under ordinary conditions, extremely difficult to flush.

The Water Rail varies considerably in size; I have noticed as much as two inches difference in the total length of adult specimens, a corresponding variation being observed in the size of certain bones, those of the sternum for instance. (Zoologist, 1886, p. 338.)

\section{THE IMOOR-HEN.}

\section{Gallinula chloropus.}

TuE Moor-hen is a common resident, found along all our streams, and on the larger ponds, a preference being naturally shown, at the breeding season, to those that are bordered with rushes and a thick growth of aquatic herbage to shelter its nest. 


\section{THE COOT.}

\section{Fulica atre.}

Tre Coot is a resident, breeding, among other places, in abundance on Clattercote Reservoir, and the lake at Blenheim; a few pairs also breed on a piece of water near the Great Western Railway Station at Oxford, and Mr. Warner was informed that it did so on the Isis in the neighbourhood of Stanton Harcourt (in lit.).

The Coot builds a bulky nest, always at a little distance from the bank, often quite floating and merely moored to the rushes and water-plants, and constantly adds to the structure during the progress of laying and incubation. The prettiest nest I have examined was moored in water about two and a half feet deep, and was composed externally, almost exclusively, of the fresh flowering plants of Nasturtium amplitizm, together with a few of Rannnculus sceleratus; more frequently it is composed of dead flags and reeds. Two broods are probably reared in the season; I have seen eggs as early as the I 5 th May, while Mr. A. B. R. Battye and I, in the same year, found three fresh eggs on the 7 th July, at which date half-grown young were to be seen on the water.

I have counted as many as eighty-four Coots on the open water at Clattercote in September, but their numbers are always greatly reduced hy the following spring, especially after a severe winter, when, the water being frozen, the Coots migrate, or wander away down the streams, and get killed. One such frozen-out bird was captured in a garden in Banbury, in January, 1886, and came into my possession. On the Thames about Henley, it is seldom that even a stray Coot appears (A. II. Cocks in lit.); but they are common in winter and early spring on the upper Isis about Newbridge (W. II. Warner in lit.).

Contrary to the opinion sometimes expressed, Coots are perfectly at home on dry land, and in the early morning may be 
seen on the grassy bank of the reservoir, actively pecking about like so many barn-door fowls. When walking in autumn down a stubble field, divided from the pool by a tall straggling hedge, some ten or twelve feet high, I have seen the Coots rise one after another like Pheasants, easily clearing the hedge, and dropping with a heavy splash in the water beyond.

The various stages of plumage which the Coot undergoes in its progress to maturity, appear to be but little known. The young when first hatehed are elothed in blackish down, with a considerable amount of chestnut about the head, the forepart of the face and head being nearly naked and of a reddish tinge; when half grown they are dark grey, with the throat, neck, and breast nearly white, losing the white as time goes on, so that by the middle of September it is unusual to see more than merely a little grey on the throat.

\section{THE COMMON CRANE.}

Grus communis.

The Crane was formerly not uncommon in Britain, but at the present day is only a very rare visitor. A female was shot at Chimney-ford, near Standlake, in the spring of 1829. (Zoologist, p. 2600.)

\section{THE GREAT BUSTARD.}

Otis tarda.

The Great Bustard formerly inhabited 'most of the open countries of the south and east parts of this Island from Dorsetshire as far as the Wolds in Yorkshire' (Pennant), and in those days, previous to the time of the Enclosures, it was doubtless found upon the open downs of Oxfordshire. From the Lambourn Downs in Berkshire it disappeared soon after I 802 (Om. Bercheria), from the plains of Wiltshire a few years later, while in Norfolk, where it lingered late, probably the last indigenous bird was killed in 1838 (Sterenson.) I have 
been unable to discover any record of the actual occurrence of the Bustard in Oxfordshire, the statement in Morris' IListory of British Bimls being erroneous; but a specimen in the possession of Mr. W. P. King, of Lower Heyford, bought by him some forty years ago at a Mr. Bates' sale at Middleton Stoney (in lit.), was probably obtained in the county a long while ago.

\section{THE LITTLE BUSTARD.}

Otis tetrax.

Tre Little Bustard, a rare visitor to England, generally in the winter, has been procured in Oxfordshire in three or four instances. A female shot in November, 1835, by Mr. Aldworth, a farmer at Garsington, and then in his possession, is recorded by the Mesis. Mathews, who also mention another, on the authority of the Rev. II. Roundell, which was said to have been killed on Denton Common in December, I 830 (Zoologist, p. 2600). Mr. William Hewet, of Reading, gave the Rev. F. O. Morris information of one shot on a farm called English, between Ipsden and Nettlebed, in 1849 (History of British Birds, vol. iv), and the Rev. Murray A. Mathew in the Zuolngist (1).6780) has recorded the occurrence of a young male shot near Oxford in October, I 859, which, as he recently informed me, he examined in the flesh.

\section{THE STONE-CURLEW.}

Edicnemus scolopax.

The Stone-Curlew, Thicknee, Norfolk or Great Plorer, as it has been variously termed, is a summer visitor, but of only very local distribution. Its favourite haunts are sheep downs, heaths, and open stony arable land-such a country as that found in parts of the north-west of the county, about Burford, and on the chalk hills in the south-but I am not aware of its breeding in more than one locality in Oxfordshire at the present day. The Burford Downs are now entirely 
under the plough, and from enquiries made in the neighbourhood the bird seems to be now unknown. The Stone-Curlew undoubtedly bred at one time in Mid-Oxon, the Rev. A. and H. Matthews including it in their list as a summer visitor, and giving the date of its arrival as from the second to the fourth week in May, and of its departure the first to the third week in September. The former gentleman also wrote me word that (previously to his leaving the county in I 854 ) it bred regularly in their own parish, Weston-on-the-Green. The Stone-Curlew formerly also bred annually in the wide, stony, arable fields on the hill above Sarsden, near Chipping Norton. In I 887, old keeper Cook, of Kingham, then over eighty, remarked to me in conversation, that we had no 'Curloos' now, and stated that when he lived at Sarsden, fifty years ago, they came regularly and bred in these fields. He described the birds very accurately, saying they were very noisy at night, and could run very fast, much faster than a Pheasant, and laid two eggs, which were very hard to find, on the bare fallow, with perhaps a few blades of squitch-grass (Triticum repens) gathered together round them. A few pairs still breed on the wide arable fields on the western slope of the Chilterns, north of Goring. In I 886 two broods of young were discovered there on the I Ith May, and on the 26th a nest containing eggs was found in the same locality. The birds were observed in the same spot the year following, and it is believed that they breed there annually. (H. Evelyn Rawson in lit.)

Occasionally specimens are procured in other parts of the county; as, for instance, one at Tangley some ten years ago, and another, now in my possession, at Great Bourton in May, I87I. 


\section{THE DOTTEREL.}

\section{Eudromias morinellus.}

The Dotterel, at the time the Messrs. Matthews wrote their account (I 849), visited us sparingly in spring and autumn, when on its passage to and from its breeding-grounds, and they gave the dates of its appearance as the fourth week in April to the second in May, and the first to the third week in October. Wherever the Dotterel appears on passage in England a great diminution in its numbers has been noticed of late years, and the only locality in Oxfordshire, as far as I am aware, now risited amnually by them, is Puddock IIill, near Crowmarsh, information respecting which has been kindly communicated by Mr. W. Newton, jun. They arrive in spring about the latter end of April or the first week in May, returning from their breeding haunts as early as the end of August, or the beginning of September, in some years, but in others not before the end of the latter month. During their stay, which rarely exceeds six or seven days, and is often shorter, they usually frequent fallows, invariably resorting to such, or to other bare ground, on being disturbed. On the spring migration the 'trips' seldom exceed fifteen or fiveand-twenty in number, but in autumn Mr. Newton has seen as many as fifty or sixty on the wing. A few examples are shot at Crowmarsh in most autumns, and $\mathrm{Mr}$. Newton has a local example in his collection. During the present spring (I 888) none were observed, owing to the fact that the ground in question, and for more than a mile round, was under crops, and unsuited to the birds' requirements. Mr. C. E. RuckKeene has a Dotterel in his collection which was shot at Swyncombe in I 859 (in lit.). The Dotterel should be looked for on open downs and fallows on the Chiltern Hills, and on high-lying open arable land, about Burford, ete. 


\section{THE RINGED PLOVER.}

Egialitis hiaticula.

The Ringed Plover is an occasional visitor to the Thames district in spring and autumn, more rarely wandering up the tributary valleys. Two were seen, about the end of March, I 852, on the banks of the river in Port Meadow (Zooloyist, p. 3476), where the Rev. Murray A. Mathew has also shot one (in lit.). In the same place two in immature plumage were shot in August, or early September, 1885 (J. E. Kelsall in lit.), and two pairs were seen on the I8th May, 1887 (W. W. Fowler in lit.). Mr. G. Arnatt has one which was shot at Stanton Harcourt, on the 22nd March, 1883. At Standlake a pair were seen, and the male shot, on the banks of the Isis, on the 5th May, I885 (W. H. Warner, MIS.). In March, 1888 , one was shot at Oxford, and another was observed by Mr. W. Warde Fowler frequenting a flooded valley at Kingham from the 18 th to the 2 Ist of that month. In the same year one was shot on Port Meadow on the gth May. Near Banbury it has once occurred on the canal, some years ago. The Messrs. Matthers record that the Ringed Plover occasionally visited the county in winter. (Zoologist, p. 2537.)

\section{THE KENTISH PLOVER.}

Egialitis cantiana.

The Kentish Plover is a casual visitor of very rare occurrence. The Rev. A. Matthews has seen two examples in the flesh while in the hands of the late Mr. Forrest, of Oxford. These were shot, before the year I 849 , on the banks of the Isis in Port Neadow, either in late autumn or early spring (in lit.).

\section{THE GOLDEN PLOVER.}

Charadrius pluvialis.

The Golden Plover is a winter visitor, occasionally appearing in spring after it has assumed the black breast 
peculiar to the breeding season, and is pretty well known as the 'Whistling Plover.' Previous to the enclosure of the open and common fields, these birds were abundant in Oxfordshire. The late Mr. T. Goatley, of Chipping Norton, stated that they 'come in considerable flocks in November' and December, and spend some time during the winter months upon the higher grounds in the neighbourhood, particularly the fields of Chadlington and Dean, between this town and Charlbury, and leave again in early spring.' (Morris, Game Birds and Milifowl.) Mr. Warner writes of Standlake,_-Common as this bird was before the enclosure of the parish, it is now of only frequent occurrence, though small flocks occasionally pass over in the autumn season' (JIS.). Standlake was enclosed in 1848 . About Oxford a few appear most winters. In the neighbourhood of Kingham it is now rare (W. W. Fowler, MS.), but in the spring of $\mathrm{I} 888$, I was informed at the 'Merry Mouth' Inn that they still came in flocks to the arable fields on the high open ground about there, between Fifield and Tangley, several flocks having been observed in the previous winter. In the northern division of the county the Golden Plover is irregular in its appearance, though flocks may sometimes be seen flying over, and occasionally stay a few days in the Cherwell valley. The Golden Plover is very susceptible of changes in the weather, and their appearance with us is usually coincident with, or immediately previous to, stormy or bad weather. Thus at the end of December, 1885 , a flock of fifty or sisty appearing in the Cherwell valley foretold the severe weather we were to experience at the beginning of the new year. In cold snowy weather, on the $25^{\text {th }}$ and 26th Mareh, I883, I observed a flock of about five hundred Plover, consorting with some Peewits, in the Cherwell meadows near Bodicote, many of which had assumed the black breast of summer. The sun shining out for a few minutes displayed the pretty effect produced by the flock wheeling and twisting in the air with the greatest rapidity; 
one moment showing dark, and the next silvery white, as they turned up against a background of black storm cloud, and the white under-wing surfaces flashed in the sunlight. Again on the I6th March, I888, an extremely cold day, I found a little party of these birds in the same valley, under Little Bourton, approaching them pretty closely under cover of a thick snowstorm. Three or four had a patch of black on the lower breast, and one was in full breeding plumage. The latest date in spring at which I have known the Golden Plover to appear here is the 7 th April, on which date, in I888, I saw a little flock consorting with Lapwings in the Isis meadows, near Eynsham.

\section{THE GREY PLOVER.}

Squatarola helvetica.

Tue Grey Plover, which is a regular, but not abundant, visitor to the east coast of England, very rarely strays inland. The Rev. A. Matthews informs me that he saw in the late Mr. Forrest's shop a specimen which had recently been shot on the Isis at Oxford (in lit.).

\section{THE PEEWIT OR LAPWING.}

Vanellus vulgaris.

The Peewit is a resident species, breeding, in some numbers, alike on the upland fallows and corn-fields, and in the rough hassocky meadows, where they appear in pairs by the end of February if the spring is mild and open, but otherwise the flocks remain in the meadows until nearly a month later; migratory flocks may be seen in some seasons as late as April. When traversing one of the foot-paths which cross many of our arable fields, or walking by the river side, the wayfarer is often mobbed by day or night (unless it is very dark) by a pair or two of Peewits, whose young are hidden in the young corn or rough grass, the birds often swooping down within a few feet of his head and producing a loud and 
peculiar 'lhumming' sound with their wings. The earlier clutches of eggs, when laid on the arable fields, are liable to be destroyed by farming operations, in which case egrgs are sometimes laid very late in the season. In 1880 , I found two newly-hatched young as late as the II th $\mathrm{July}$, by which date the earlier young are on the wing. As a breeding species the Peewit is less numerous than in former years. Mr. Arnatt tells me that many year's ago, when the drags were being taken over one of his fields at Stanton Hareourt late in spring, no less than fifty nests were found in the thirty acres.

At the close of summer the broods gather together into flocks, feeding on the fallows and in meadows, and later in the autumn are joined by migratory bands, the flocks or 'congregations,' to use the old term, being then often of very considerable size. At the end of September, I885, I observed a flock in the valley, near Adderbury, which must have numbered twelve or fifteen hundred birds. In rarying and smaller numbers the flocks remain during the winter in the milder seasons only, disappearing entirely in severe weather, and returning usually within a few days of the breaking up of the frost. In some districts, especially the drier portions of the county, they never stay the winter; this is the case in the Chiltern district, where they were observed to reappear about the end of February (B. D'Oyly Aplin).

It does not seem to have been generally noticed that the colour of the Lapwing's legs varies in summer and winter. One killed on the I 7 th June had the legs and feet bright coral red; in an adult shot on the 24 th December these parts were dark purplish-brown, and rather paler in a young bird of the year procured at the same time.

\section{THE TURNSTONE.}

Strepsilas interpres.

THe Turnstone, a casual wanderer from the coast, has been procured twice close to Banbury, namely in 1860 , and in 
November, I874 (J. Gardner and W. Wyatt), and the Rev. A. Mattherrs has seen an example in the late Mr. Forrest's sh'pl which was shot on the banks of the Isis at Oxford (in lit.).

\section{THE OYSTER-CATCHER.}

\section{Homatopus ostralegus.}

Tre Oyster-catcher is a casual visitor from the coast. It is included in the list of visitors in winter by the Messrs. Matthews (Zoologist, p. 2535). One was shot on the Isis, at Bablock Hithe Ferry, near Stanton Harcourt, about October, 1878 (H. A. Macpherson, MIS.), another near Great Bourton in September, 1852 (W. Wyatt), and a third specimen, in Mr. G. Arnatt's collection, was procured at Stanton Harcourt on the I8th September, I879.

[The Arocet (Recurrirostra arocetta). Dr. Lamb records that six of these beantiful birds were killed at one shot while swimming on a pond at Sonning, near Reading, in April, I 794 (Ornithologia Berclieria). Sonning is on the Thames, chiefly in Berkshire, but partly in Oxon; and the occurrence is mentioned here because the birds were procured very close to, if not actually within, our borders.]

\section{THE BLACK-WINGED STILT.}

\section{Himantopus candidus.}

THE Black-winged Stilt, an accidental visitor to this country from Southern Europe, has occurred twice in Oxfordshire. Pennant, writing of the 'Long-legged Plover', mentions one 'shot a few years ago on Stanton Harcourt Common, near Oxford.' (British Zoology, I8I2, vol. ii, p. IOI.) Another, killed at Shiplake, near Henley, was for some time in the possession of Dr. Kirtland, who obtained it soon after its capture, and afterwards passed into the collection of the Rev. H. Roundell, of Fringford (Zoologist, p. 2602). 


\section{THE GREY PHALAROPE.}

Phalaropus fulicarius.

'The Grey Phalarope is a rather rare occasional visitor in autumn and winter. The specimens procured are usually in the immature, or adult winter dress, but in one instance an example which had partly attained its summer plumage, was brought to the late Mr. Forrest, of Oxford, from that neighbourhood, as recorded by the Messrs. Matthers, who note it as more frequent in its winter dress, and mention one in their collection, shot at Weston-on-the-Green in September, I823 (Zuoloyist, p. 2602). The following occurrences may be enumerated. One near Chipping Norton, 3ist December, 1831 (T. Goatley, Loudon's ILayasine of Tatural Itistory, I832). One, immature, September, and one in adult winter plumage, December, 1852 , Port Meadow (Hon. T. L. Powys, Zoologist, I 853 , 1. 3805). One on the Thames at Whitchurch, I 9 th September, I 866, during the memorable immigration of this species to England that autumn, recorded in a pamphlet upon the subject by Mr. J. II. Gurney, jun. One at Inenley, being the third shot there, 24th Octuber, I 870 (Stubbs, Zoologist, ss, p. 2442). One, immature, on the Cherwell at Franklin's Knob, below Banbury, in the winter of 1876 . One at Bloxham and two at South Newington (C. MI. Prior, Banbury Guardian). One, adult, on the Isis at Newbridge, I Ith December, I 88 I (Warner MIS.). One, in fine adult winter plumage, on the canal, a mile north of Banbury, 22nd December, I882. One in the same year on Port Meadow, Oxford, in Mr. G. Arnatt's collection. One, male, Bletchingdon, I8th October, I 886. One seen on Port Meadow, 2oth January, I887, by Mr. A. II. Macpherson, who approached within a short distance of it, as it stood in some shallow half-frozen flood-water bathing and trimming its feathers. 


\section{THE RED-NECKED PHALAROPE.}

Phalaropus hyperboreus.

THe Red-necked Phalarope has occurred on one occasion only, namely, in the winter of 1834 , when one was found in an exhausted condition on Shotover Hill, near Oxford (Zoologist, p. 2538).

\section{THE WOODCOCK.}

Scolopax rusticula.

Tre Woodeock, a regular and well-known winter visitor, is never very plentiful, and in some parts of the county it is even rare. About Kingham it is an occasional visitor only, and in the northern part of the county (except in one or two favoured spots) a few only are shot each year. The same may be said of the woods at Nuneham. In Coggs Coppice, near Witney, on a flinty soil, Mr. Harcourt tells me that Woodcocks are much more plentiful than in Tar Wood, near Stanton Harcourt, on the clay.

The Woodcock has remained to breed in Oxfordshire in several instances. Mr. Thomas Goatley, in a note dated the Ioth April, I848, and quoting probably from a local newspaper, says - 'A few days ago a Woodcock's nest, with four eggs in, was discovered in Waterperry Wood, near Oxford, belongingto J. W. Henley, Esq., M.P., by a gentleman residing' at Wheatley; the nest was built in a bank, and composed chiefly of dry moss. The old bird was sitting on the eggs when the nest was found.' Mr. Goatley also mentions two other instances which had come to his knowledge, one at Ditchley, and the other on the Eynsham Hall Estate, in both of which cases the young birds were shown to him (Zoologist, p. 2I48). Mr. Arnatt has two fledgling Woodcocks which were captured, some forty years ago, in the meadows at Eynsham, and Daniel mentions that 'a couple of young Woodcocks, about half-grown, were caught by a countryman in Shrub Wood, in the Parish of Caversham, Oxon, 
and exhibited as a curiosity to many inhabitants of Reading; a third was seen, but could not be taken.' (Rural Sports, Supplement, I813.)

On the I5th February, I 888 , the morning following the screre snowstorm, a half-stupefied Woodcock was picked up in the quadrangle of Wadham College (W. W. Fowler in lit.).

Two forms of the Woodcock are known to visit England in autumn, namely, a rather large greyish bird, and a smaller rufous-tinted form. I have examined specimens of both these procured in North Oxon.

\section{THE GREAT SNIPE.}

Gallinago major.

THe Great Snipe is only an oceasional visitor. The Messrs. Matthews record that' a ferr specimens have at different times heen killed in this part of the county. The last of them was shot on the banks of the Isis, close to the city of Oxford, in I 839.' (Znolongist, p. 2537.) One, weighing eight ounces, was shot at Oxford at the end of September, I85 I (A. M. Norman, Zonlegist, p. 3330). and it was probably this specimen which Mir. N. Rowe referred to when he informed the Rev. F. O. Morris that one was shot, in the winter of $185 \mathrm{I}$, in a sandpit on the road from Oxford to Botley. Mr. Norman also mentions another killed in the same place ten years earlier, which may be the one preserved in the University Museum, labelled Botley Meadow. The Hon. T. L. Powys (now Lord Lilford), recorded the occurrence of a Great Snipe, in the middle of September, I 853 , on the Buckinghamshire horders, near Waterperry (Zoulogist, I854). Another, in the possession of the Rev. Murray A. Mather, was shot on the (hrist Church cricket ground, Oxford, in I 857 (in lit.). Mr. IV. Newton, jun., has a Great Snipe which was shot in a piece of cow-grass, on Harcourt Hill, near Benson, on the 29th August, I868. At Bampton one was procured on the and 
September, I 878 (Zoologist, ı 879, p. r29). River-side gunners on the upper Isis speak of shooting 'double Snipe,' a name given by sportsmen to this species, but on enquiry Mr. II. II. Warner has always found that they mean the Common Snipe. The latter is properly termed the 'full,' and the Jack the 'half' Snipe. The Solitary Snipe visits England early in autumn, and should be looked for in drier situations than those affected by its congeners.

\section{THE COMMON SNIPE.}

Gallinago colestis.

Tine Common Snipe is usually regarded as a ninter visitor, but it is always more numerous at the periods of migration, and most so in autumn. There is no record of the Snipe having bred with us, although doubtless it did so on Otmoor in former years. Mr. Warner indeed was informed that it had been known to breed at Newbridge, but was unable to obtain satisfactory confirmation of the report (IIS. notes). After wet summer's Snipes sometimes arrive here in large number's in August. The Messrs. Matthews in that month in $18_{3} 8$ witnessed 'the passage of a flock which must have contained several thousands of these birds; they were at the time proceeding in a southerly direction, at a tolerably slow pace, and occupied a considerable time in passing.' (Zooloyist, p. 2537.) The late Rev. T. W. Falcon wrote me word of a great visitation of Snipes at Charlton-on-Otmoor; he says, 'Some years ago, after a slight flood in August, we were visited by thousands of Snipe, which covered my meadows as thick as ever you see Starlings. I used to watch them in the evening probing the soft mud, and if I clapped my hands the air was instantly filled with a long-billed crowd, which circled once or trice over my head and then settled again. They were mostly young birds and very tame. What direction they came from I know not; they remained here about ten days' (in lit.). After the wet summer of 1879 , when the 
meadorvs at the junction of the Sorbrook and Swere with the Cherwell stood a foot or eighteen inches deep in water, and were more or less covered with reeds, in places as high as one's head, I saw fire Snipe as early as the 8th August, and early in the following month flushed upwards of fifty couple from one small meadow. A few Snipe always put in an appearance in the early part of September, even in dry seasons, when they are usually found along the streams, but the main Hight occurs from the middle of October to early November, their numbers and stay depending entirely upon the state of the meadows. In varying numbers they remain the winter through, even in severe frosts, appearing and disappearing in greater plenty with changes in the weather.

In March birds on the return flight northwards are observed, especially if there is any flood in the meadows, while individuals are occasionally seen well on into April. When out with the Otter hounds, between Somerton and Heyford, in April, I875, I saw one which attracted the notice of many of the field, and Mr. A. H. Cocks reminds me that this took place on the 26th of the month. On the evening of the gth April, I884, I saw two flying over Great Bourton village. The Snipe has not, to my knowledge, been observed in May or June, but the Rev. B. D'Oyly Aplin saw one in July, at Bodicote.

The Snipe usually weighs about four, or four and a quarter, ounces, but, at the commencement of the frost in December, I 878, I shot one weighing a trifle over five ounces. Daniel mentions that the Duke of Marlborough's keeper killed twenty-two Snipes at one shot some years previously (Rural Sports, I807).

\section{THE JACK SNIPE.}

Gailinago gallinula.

THE Jack Snipe is a regular winter visitor in small numbers, usually arriving early in October. The earliest date for its 
arrival of which $I$ have a note is the 15 th September, in 1882 , when one was shot on the Cherwell, near Bodicote. In spring I once saw one near Adderbury on the I5th March, in I879, and when Otter liunting near Heyford, as late as the 26th April, in 1875 , the hounds flushed a Jack Snipe which was seen by Mr. A. H. Cocks. In October, 1880, when both Jacks and 'full' Snipe were unusually numerous, we bagged nine in one meadow during the first fortnight, but generally it is rather a scarce bird. Occasionally specimens are picked up under the telegraph wires, against which they have struck in the night, and, solitary as the Judcock usually is, two, which were picked up, lyiag togrether under the wires, on the I 8th November, I885, were apparently flying in close company. One of these birds scaled fully three ounces, which is the heaviest I ever weighed.

The Jack Snipe has not been proved to breed anywhere in Great Britain, but specimens have been seen and obtained in this county in summer. One was picked up on the railway at Oxford in August, I 882 (H. A. Macpherson, MS.), and another near Banbury at the end of July, I883; the latter was in a very emaciated condition, and was probably an injured bird unable to migrate. Mr. W. Warde Fowler mentions that in the summer of I 884 , a Jack Snipe was several times flushed by a good observer, who knew the bird well, in the Parks by the Cherwell at Oxford. (A Year with the Birds, p. I3.)

\section{THE DUNIIN.}

\section{Tringa alpina.}

The Dunlin, a common coast bird, is an occasional visitor to Mid-Oxon and the Thames district. The Messrs. Matthews stated in their list that it was a common winter visitor, occasionally met with after it had partly assumed its summer plumage, but at the present day it appears less frequently. On the 25th April, I 887, Mr. A. H. Macpherson saw forty or fifty on Port Meadow, some of them being in full breeding 
dress, and a specimen in remarkably fine plumage, now in his possession, was shot there on the 9th May, 1888. In the north of the county it has occurred more rarely. One was shot while wading in company with two others in a partlyflooded meadow at Souldern, on the 9th November, I883 (F. Stanton in lit.), and in severe weather, on the 20 th Mareh, I 888, Mr. W. W. Fowler observed a single bird in one of the Evenlode meadows (which had been artificially inundated) at Kingham. On the $4^{\text {th }}$ November, 1888 , I distinctly heard the whistle which the Dunlin utters on the wing, in some partly-flooded meadows at Kingham; the light was bad, and I could not detect the bird. A few minutes later a Curlew flew over.

\section{THE IITTLE STINT.}

Tringa minuta.

The Little Stint is a rare occasional visitor. The Messrs. Matthews record that several had been killed near Oxford, the oceurrences, as far as they remembered, being always in spring or autumn, and they particularize a pair shot by the late Mr. Pinfold, of Beaumont Street, in the spring of $1_{32}$ (Zoologist, p. 2602). The Rer. II. A. Macpherson kindly communicates the fact that among the correspondence of the late Mr. T. C. Heysham, of Carlisle, is a letter from the Rev. G. Clayton, of Marsh Hadham, Herts, dated 17 th December, 1832 , in which the latter mentions having shot a Little Stint at Oxford.

\section{TEMMINCK'S STINT.}

\section{Tringa temmincki.}

Temminck's Stixt is a spring and autumn visitor to the shores of Great Britain, but of much less common oceurrence than the preceding species. It has occurred in Oxon as an occasional visitor, but very rarely. A pair shot on Port Meadow, on the 24th August, 1848 , are mentioned by the Messrs. Matthews, who remark that it had been 'found in the 
same neighbourhood on other occasions, but rarely.' (Zoologist, p. 2602.) Another was shot in the same locality in September, I 852 (Hon. T. L. Powys, ib., p. 3805 ).

\section{THE CURLEW SANDPIPER.}

Tringa subarquata.

THe Curlew Sandpiper is an oceasional visitor of rare occurrence. An example seen in the flesh at the late $\mathrm{Mr}$. Forrest's shop by the Rev. A. Natthews, which had been shot on the banks of the Isis at Oxford, is the only instance of its occurrence that I am aware of. It was procured at one of the periods of migration (in lit.).

\section{THE PURPLE SANDPIPER.}

Tringa striata.

The Purple Sandpiper is rarely seen inland. The Rev. A. Matthews saw an example in the flesh, while in the late Mr. Forrest's hands, which was shot on the river at Oxford (in lit.).

\section{THE KNOT.}

Tringa canutus.

THE Knot is an occasional, and uncommon, visitor from the coast in winter. Some examples in winter dress were shot some years ago by professional gunners on Otmoor, and taken to the Rev. A. Mattherws (in lit.). It has also been met with at Oxford (Zoologist, p. 2537).

\section{THE SANDERLING.}

Calidris arenaric.

The Sanderling rarely wanders inland, being, as its name denotes, devoted to the sands, and during its stay on our coasts is seldom seen far from the tide edge. As a casual visitor it has occurred in Oxon on one occasion, when a specimen was shot by a professional gunner on Otmoor, and taken to the Rev. A. Mathews (in lit.). This is the 
only authenticated occurrence of the Sanderling in this county of which I have notice, the reports by sportsmen of their meeting with it on the banks of our rivers and streams having reference either to the Green or to the Common Sandpiper.

\section{THE RUFF.}

Machetes pugnax.

The Ruff and Reeve, as the male and female of this species have always been designated, formerly bred commonly in the fens of the eastern counties, but in consequence of the drainage of that part of the country, and the persecution which the birds suffered in the breeding season, they have for many years ceased to breed save in one or two favoured spots; at the present day it is best known as a passing visitor to England in spring and autumn.

It is quite possible that in former years the Reeve may have nested in this county, upon Otmoor, but there is no evidence of its having done so. The Messrs. Matthews wrote that it was often found in their neighbourhood in winter, but they never met with it in the summer plumage; a specimen of the Ruff, which they obtained at the end of April, showed no appearance of any change (Zoologist, p. 2537). In this record ' autumn' should be substituted for ' winter.' There is a specimen in autumn plumage, labelled 'Yarnton,' in the University Museum, and Mr. G. Arnatt has an immature bird, which was shot in the meadows at Stanton Harcourt on the 23 rd September, after the wet summer of 1879 .

\section{THE COMMON SANDPIPER.}

Totanus hypoleucus.

The Common Sandpiper, a summer visitor to Great Britain, breeding regularly in the north and west, is a passing visitor to Oxon in spring and autumn. At the former season it is occasionally observed in the last days of April, but as a rule its appearance may be looked for during the first week in 
May. In spring it stays but a few days, but on its return in autumn, which is sometimes by the last week in July, it remains longer, but never very late, and the $15^{\text {th }}$ September is the latest date on which I have myself met with it.

The Common Sandpiper, or Summer Snipe, may very possibly have bred in the county oceasionally. One instance of its so doing, about May, I 885 , has been communicated by the finder of the nest, Mr. A. F. Hall (then at Balliol College), to Mr. W. W. Fowler. The nest, a mere depression in the soil, with two or three dead stalks drawn together, was on a little island just past the junction of the Glyme with the Evenlode, and contained the usual complement of four eggs. I once saw a Sandpiper on the banks of the Isis at Nuneham as late as the 27th May, but it showed no signs of breeding there. The Messrs. Matthers observed a pair on the margin of the lake in Kirtlington Park, on the Ist July, I849, which, from their unwillingness to quit the spot, they were led to suppose had a nest not far distant.

The Common Sandpiper during its stay with us, frequents the low shelving banks of our rivers, canal, and larger ponds. A party of these little waders on a bright spring morning, running nimbly about on some grassy bank at the water side, with their delicate greyish-brown and white plumage, form as pretty a sight as the ornithologist can meet with. They are always in motion, their tails gently swaying up and down, their heads nodding-now darting forward with a quick run to pick up a worm in the grass, or wading into the shallow water to snatch a morsel from the surface, and then perhaps rising with their quick, shrill cry, 'weet, weet, weet,' to fly a short distance along the stream, exposing in flight the white on the wings and the barred outer tail-feathers. In stormy weather, on the 3 rd May, I884, when watching through my glasses a little party of half-a-dozen of these birds which were running about with some Yellow Wagtails on the grassy bank at Clattercote Reservoir, the wavelets lashed up by the strong 
wind frequently breaking over them when they ventured down the stones to the water's edge, I observed one draw out a worm from the turf with the exercise of some force, after the fashion of a Thrush. The Sandpiper always utters its cry on the wing, and the course of its flight is invariably along the middle of the stream, following its windings; when flushed from the banks of a sheet of water, it flies out a short distance before pursuing a course parallel to the shore.

The only instance of the Sandpiper visiting Oxon between September and the third week in Anril, of which I have had notice, happened in I888, in which year $\mathrm{Mr}$. W. C. Darbey informed me of two brought to him in the first fortnight of March.

\section{THE GREEN SANDPIPER.}

Totanus ochropus.

Tre Green Sandpiper is a spring and autumn visitor, occasionally remaining during the winter. On its autumn passage it often reaches us in July, the Igth of that month being the earliest date upon which I have met with it. The Messrs. Matthews observed a family of six of these birds, four young fully grom and the two old birds, by the side of a pond at Westun-on-the-Green on the $26 \mathrm{th}_{\mathrm{Ju}} \mathrm{J}$, I 838 ; nevertheless, there is no proof of its having bred in this county, or indeed anywhere in Great Britain. During August the visits of the Green Sandpiper are more frequent, but after the latter part of September it is less often seen, save in exceptional seasons. In I $88+$ many of these birds remained here very late; I saw five on the mud at Clattercote Reservoir on the Sth November, and a single one at the same place on the 22 nd of that month; one killed by the telegraph wires at Somerton on the I 9 th was received by me in the flesh, while $\mathrm{Mr}$. W. W. Fowler as late as the 24 th December observed two in the Evenlode, at Kingham. In I 879 I met with one in the Cherwell, at Bodicote, on the 2 and November, during the prevalence of severe frost, with two or three inches of snow on the ground. In February, 
the Hon. T. L. Powys (now Lord Lilford) shot one on Port Meadow on the and in 1853 (Zoologist, p. 3805 ), and the late Rev. T. W. Falcon, writing on the 3 rd of that month, I88 I, mentioned one brought to him 'the other day' (in lit.). In spring the Green Sandpiper is of less frequent occurrence; I have seen it twice in March, on the 15 th and 26 th in successive years.

During its stay with us it frequents the low under-banks of streams and ponds, where it feeds on various insects and worms: the stomach of one killed in Norember contained the elytra and other remains of numerous small beetles.

On the wing the present species may readily be distinguished from the Common Sandpiper by its conspicuous white upper tail-coverts, and nearly white tail, the latter being only barred on the distal half. When on the bank its larger size, and nearly white breast, will be noticed. The note of the Green Sandpiper is fuller and louder than that of its congener, and may be syllabled 'tul-a-vee-wee.'

The strong musky odour of this species has been remarked upon by some authors, but others have not noticed it (ef. Yarrell). An adult bird shot on the 21st August, I884, had hardly any trace of it, and the man who skinned it for me ate the body and said it was excellent; while in another, in immature plumage, procured a week later, the scent was so strong as to necessitate washing the hands after handling the bird, and the skin still retains it.

[The Wood Sandpiper (T. glareola), the nearest ally of the Green Sandpiper in the British Isles, has been included in the Ilistory of Banlury list, as 'an occasional visitor,' but as no mention is made of the latter species it is probable that the two were confused. In the event of the Wood Sandpiper occurring in Oxon it may easily be distinguished by the shaft of the outer wing feather, which is white instead of black.] 


\section{THE REDSHANK.}

Totamus calidris.

The Redshank is an occasional visitor. The Messrs. Matthews included it in their list of winter visitors (Zoologist, p. 2535), and the Rev. F. O. Morris mentions its occurrence near Bampton (History of British Birds, vol. iv, p. I 95). There is a specimen in summer plumage in the Oxford Museum, labelled Port Meadow, and in September, I886, one was shot at Chorton, near Islip.

\section{THE SPOTTED REDSHANK.}

Totanus fuscus.

TuE Spotted Redshank, a rare visitor, has occurred in four instances in Oxfordshire. In February, I 835, a female, and in the following February a male and a female, were shot on Otmoor (Matthews, Zoologist, p. 2537). A specimen in immature plumage, now preserved in Banbury, was procured, as I am informed by its owner, who shot it many years ago, on the Cherwell at Huskott Mill, near Banbury. After the exceptionally wet summer of I 879 , three Spotted Redshanks, in immature plumage, were shot at Stanton Harcourt on the 23 rd September, and are now in MIr. G. Arnatt's collection.

\section{THE GREENSHANK.}

Totanus canescens.

The Greenshank is an occasional visitor of uncommon occurrence. A pair in the Messrs. Matthews' collection were killed near Oxford in January, I 838 (Zoologist, p. 2537), and in the same periodical, Mr. A. H. Smee records that he saw one feeding with some Common Sandpipers in a shallow in the Isis, between Oxford and Eynsham, on the I 5 th August, I873 (ib., ss, p. 3803). An immature bird, exhibited at a meeting of the Oxfordshire Natural History Society, was shot on the river near Old Shifford on the Ioth November, I 882 (W. H. Warner, MS.). Mr. W. Newton, jun., has one 
which was shot at Bensington, and another, preserved in the Trout Inn, near Bampton, was procured at Radeot Bridge higher up the river some years ago. The Rev. F. O. Morris records the occurrence of others near Bampton and Brighthampton. (History of British Birds.)

\section{THE BLACK-TAILED GODWIT.}

Limosa agocephala.

Tre Black-tailed Godwit, at the present day only a visitor to our coasts on migration, though formerly nesting in the English Fens, has rarely occurred in Oxfordshire. The Messr's. Matthews record two or three specimens shot in the neighbourhood of Weston-on-the-Green, and also, on the authority of Mr. Roundell, one in summer plumage procured near Fringford, a few years previous to I849. (Zoologist, p. 2602.)

\section{THE BAR-TAILED GODWIT.}

\section{Limosa lapponica.}

The Bar-tailed Godwit is a common visitor to our coasts on migration. In Mid-Oxon, according to the Messrs. Matthews, it was often seen at the date they wrote their account of the birds of this county, but it is certainly much rarer nowadays, no instance of its occurrence having come under my notice in recent years. A specimen in the University Museum, procured on Port Meadow, was presented by the late Mr. A. E. Knox, and Mr. C. M. Prior records that three have been shot in the north of the county. (Banbury Guardian.)

\section{THE CURLEW.}

Numenius arquata.

The Curlew is an occasional and not uncommon visitor in spring and autumn, less frequently in winter, being usually seen in small flocks. Of recent occurrences may be mentioned : one shot from a flock at Deddington, in the winter of 1879 ; eighteen seen on Port Meadow, 26th November, I 885 (A. H. Macpherson); four seen at Kingham, I2th March, I886 (W. 
W. Fowler). One shot at Heyford, September, I886; one shot from a flock at Steeple Aston, and September, I 887 ; one seen in a flooded meadow in the Evenlode valley at Kingham, Igth and 2oth Mareh, I888 (W. W. Fowler). When I was walking with Mr. W. W. Fowler in the partly-flooded meadows along the brook at Kingham, on the $4^{\text {th }}$ November, I888, a dull cold afternoon following twenty-four hours of rain and wind from the sonth-east, a single Curlew passed twice over us, uttering its loud whistle, cour-lien, the second time quite low down. Another was seen in the Sorbrook valley, near Adderbury, a few days later.

\section{THE WHIMBREL.}

\section{Numenius phceopus.}

The Whimbrel crosses Oxfordshire on its vernal and antumnal migrations, occasionally alighting at the former season, when it has been procured in the county. In I880 one was shot at Bloxham on the 2yth April, but the second week in Nay is the more usual time of its appearance. In 1885 a Whimbrel remained at least two days, $9^{\text {th }}$ and Ioth May, at Clattercote Reservoir, attracted by the rank vegetation which had sprung up on the mud left dry when the water was drawn off the previous summer, and, on account of the small rainfall during the winter, still not entirely submerged. At Thame a female was shot on the 2ist May in the following year. In 1887 , I observed the Whimbrel crossing this parish on its passage both to and from its breeding-grounds. A little before midnight on the $5_{5}$ th May, the night being dark and cloudy, with a light wind from north-east, I heard several flying due north, constantly uttering their unmistakable seventimes-repeated whistle, 'tee-tee-tee-tee'; again, on the 2oth August, about the same time, a calm clondy night, I heard them passing in a south-westerly direction. No instance of the Whimbrel being shot here in autumn has come under my notice. 


\section{THE BLACK TERN.}

\section{Hydrochelidon nigra.}

The Black Tern is an occasional visitor to our rivers in spring and early autumn, one or more occurring every year. Adult birds in breeding dress generally appear in May, but in one instance I have known an example shot near Banbury in the last days of April, and Mr. C. E. Stubbs has recorded the occurrence of another at Henley in June (Zoologist, ss, p. 2684). In autumn it revisits us in August and September, young birds, with mottled heads and white underparts, being naturally more often met with then than the adults. Two specimens in the immature dress, procured on Port Meadow, are in the University Museum.

The following examples of the Black Tern have been procured during the last five years: one, adult, on the Isis near Kelmscott, May, 1884; one, immature, Wescot Barton, 21 st August, I 884; one, immature, Banbury, 9th September, 1885 ; one, adult, Banbury, 3oth April, 1886; one, adult, Oxford, 7th May, 1886; one, adult female (of two seen), Oxford, 3oth May, I887.

The Black Tern formerly nested in the English Fens, and the Rev. Murray A. Mathew was informed that it bred on Otmoor at the time he was in residence at the University, at Merton (1 855-60). He writes-'I never took the Black Tern's nest myself on Otmoor, but was told by several (old Osman among the number) that it was breeding there in my time' (in lit. I 5 th June, I886). Osman was an old and well-known Oxford bird-stuffer. Previous to his leaving the county in 1854 , as he kindly informs me, the Rev. Andrew Matthews had never heard of the Black Tern nesting in this locality, and I have been unable to glean any further information respecting it, but it is quite possible that it may have done so. 


\section{THE SANDWICH TERN.}

Stema cantiaca.

Tre Sandwich Tern is a rare visitor. The Messrs. Matthers mention, on the authority of Dr. Kirtland, that one was shot near Oxford on the 24th August, I 847, and also that it had been killed on Otmoor. The Hon. T. L. Powys (now Lord Lilford) recorded the occurrence of three adult specimens, which were shot on the Isis near Oxford, on the 23rd April, 1853 (Zoologist, p. 3946), and another found in a small birdstuffer's shop in Clifton Hampden, near where it was said to have been shot in 1879 , was exhibited at a meeting of the Oxfortshire Natural IIistory Society, in November, 1882 , by the Rev. H. A. Macpherson.

\section{THE ROSEATE TERN.}

Stema dongalli.

Tre Roseate Tern is a rare visitor. Mr. Thomas Prater, of Bicester, in a note dated I 7 th August, I 848, has recorded that a fine specimen was shot on a large piece of water in Tusmore Park, and was then in the hands of Mr. Osman, the Oxford bird-stuffer (Zoolngist, P. 223I), and Mr. T. Goatley informed the Messrs. Matthews that this beautiful species had twice been killed on the Isis, near Oxford (it., p. 2624).

\section{THE COMMON TERN.}

Sterna fuviatilis.

Tre Common Tern is a frequent visitor at the periods of migration, at which times it is its habit to wander up rivers. It is therefore naturally more frequently met with on the Isis and Thames than in other parts of the county, yet it often strays up the Cherwell valley to the extreme north. From the latter end of April its visits may be looked for, and in May small flocks even have sometimes been seen gracefully playing in the air over the Thames, but it is not often observed after that month, though instances of its occurrence 
in early June are not unknown. Previous to its departure from these shores in autumn it reaches us sometimes at the end of August; and even as late as the second week in October, in the exceptionally mild autumn of 1886 , large numbers visited Oxford (A. H. Macpherson).

\section{THE ARCTIC TERN.}

Stema macrura.

The Arctic Tern is an occasional visitor, but of much less common occurrence than the preceding species. In a few instances it has wandered to the north of the county.

A curious, and indeed, as far as England is concerned, mique, instance of this species breeding in an inland situation is recorded by the Messrs. Matthews. The nest, which contained four eggs (an unusual number), was found on Otmoor in the summer of 1834 (Zoologist, 2624). The Rev. A. Matthews, in reply to my encuiries, writes-' I did not see the nest in situ, for I only heard of the occurrence after Mr. Forrest had the birds and nest in his possession, but think he çould be trusted' (in lit.). Unusual, and even unlikely, as this event may at first sight appear, it must be remembered that the Arctic Tern is stated to breed on fresh-water lakes in Northern Europe.

\section{THE LESSER TERN.}

\section{Sterna minuta.}

The Lesser Tern is an occasional visitor to the Thames, occurring in most years in April, May, or June, but I have never heard of its appearance in autumn. In one instance only has it wandered to the north of the county, namely, on


Banbury; others occurred at Oxford about the same time. In the west of the county a Lesser Tern was shot, on the $4^{\text {th }}$ Nay, I888, at Little Milton, on a small tributary of the Evenlode. 


\section{THE SOOTY TERN.}

\section{Sterna fuliginosa.}

The Sooty I'ern, an accidental visitor from the warmer portions of the world, is of extremely rare occurrence. One of the only two well-authenticated instances of its being obtained in England is recorded by Mr. J. E. Marting, who examined an example, in the flesh, which was shot, on the 2 ist Jume, while flying over the Thames at Wallingford, Berks, which here divides that county from Oxfordshire. It was then in the possession of Mr. Franklyn (ville Field, 26th June, 1869 ).

\section{THE BLACK-HEADED GULL.}

Larus ridibundus.

THE Black-headed Gull is an inland breeding bird, and resorts to the land for food in winter to a larger extent than the other common species of Gull. Consequently it might be expected to visit this county more frequently than any other kind of Gull, but such is, however, haraly the case; nevertheless it is a pretty constant visitor at various times of the year. Joung birds in their first plumage have sometimes occurred. In July, I 885, three or four in this stage were procured in the northern division; these in all probability had not been to the sea, but had come to us from one of the Gulleries of Lincolnshire or Norfolk, by wandering along some river, which they are fond of doing at that season. The Ouse, the Welland, and the Nene, aided by eanals, form waterways along which Gulls could easily travel from those counties to North Oxon. The Black-headed Gull also often occurs in its winter dress, and in early spring, when perhaps driven inland by bad weather on the coast, or when following the line of the probable migration of Gulls, to be more fully spoken of when treating of the next species. During the cold, snowy weather of March, I 888, a considerable number of Gulls visited several parts of Oxfordshire, and, although only one specimen was 
procured, I have reason to believe that most of those observed were of this species. They were seen on the $15^{\text {th }}$ in the Cherwell valley, above Banbury; in large numbers in the Evenlode valley, near Yarnton (W. W. Fowler); and flying up the Windrush valley at Burford; one was picked up dead at Woodstock, and another was observed and identified at Kingham on the 18 th.

I am aware of but one instance of this species being shot in Oxon after it has assumed the characteristic brown-black head which distinguishes it in its summer dress; but four which were shot, out of a flock of forty or fifty, in the Cherwell valley, near Williamscote, on the 27th February, 1888, during the severe weather and deep snow which prevailed that month, were becoming dark about the head, and Mr. W. W. Fowler observed one in the Evenlode meadows at Kingham on the 18 th of the following March, which appeared to be considerably advanced towards summer dress.

\section{THE COMMON GULL.}

Larus canus.

Tre Common Gull is a frequent visitor to the Thames district between autumn and spring; more rarely in summer. It also often occurs in the north, and some other parts of the county. The dry north-west, where the valleys are smaller, naturally has less attractions for it, and, though Gulls are sometimes seen flying over, and this species has been killed on the uplands above Fifield, they rarely seem to linger here. In the wet weather of July, I882, however, a pair of Common Gulls stayed at least one whole day in the 'Yantle' meadow at Kingham, wading in the floods for food (W. W. Fowler, MS.).

Althongh Gulls are usually considered in the light of sealirds, they are in the habit of resorting in numbers to the land to feed, especially in bad weather; and I wish to point. out that the frequent visits paid to us by the present and allied 
species are far from being accidental, or the result of the birds having lost their way, or been storm-driven, as in the case of Petrels and some other birds. Stress of weather to some extent it doubtless is which brings them here, but they have only wandered rather further than usual while following their common practice of going inland for shelter and food, when stormy weather makes it impossible to fish in, or to sit on, the sea. Another reason for their presence with us must not be overlooked. It has been surmised that the Gulls we see flying overhead may be merely taking a short cut across a portion of England, from the Wash to the Bristol Channel, or vice versi. This cause seems the more probable from the fact that far more Gulls are noticed in spring and autumn, when their migrations would take place, than at other seasons. The flight from the Wash to the Severn in autumn would be an extremely likely movement, especially considering the prevalence of south-westerly winds at that season, and the partiality of Gulls for flying against the wind, as shown by Mr. J. H. Gurney, junr. (Trans. Norfolk and Norwich Nat. Society, vol. iv, p. 326.) I have many notes of Gulls in flocks, and singly, taking that direction in autumn, and the opposite course in spring.

\section{THE HERRING GULI.}

Larus argentatus.

The Herring Gull is an occasional, and not at all uneommon, visitor, generally in spring or autumn. It is seldom that these Gulls alight, and they are usually seen passing orer. On the 2nd September, I887, after a furious storm from the south-west the previous night, a flock of Gulls was seen by a friend of mine flying over Adderbury, against the south-west wind, which was still high; these had no doubt come from the Wash, and their line of flight would take them to the Bristol Channel. From the description given, they were probably of this species, and a Herring Gull which was picked up some 
days after, having died from shot wounds, a few miles off in Warwickshire, was doubtless one of the flock. I saw two immature Gulls, apparently of this species, flying over Bodicote in the same direction on the 7 th September, 1884.

Mr. Prior mentions a Herring Gull shot at Swerford in I 876 (Banbury Guartian), and others also have been procured in the north of the county. Mr. Fowler observed a Herring Gull in a flooded meadow in the Evenlode valley, at Kingham, on the I9th and 2oth March, I888.

\section{THE LESSER BLACK-BACKED GULL.}

\section{Larus fiescus.}

The Lesser Black-backed Gull is an occasional visitor, perhaps rather less common than the preceding species; in immature dress, however, they are very similar in appearance, and it is impossible to say to which species the flocks of this sized Gull (which are generally composed of individuals in this plumage), seen flying over, really belong. In stormy weather (wind north-east, backing to north-west) on the I th May, 1886, a flock of Gulls passed over Oxford, progressing in a northerly direction - an instance of the return journey over the usual route, but a little to the south of the direct line. These were probably Lesser Black-backed Gulls, as an example of this species was shot the same day on Port Meadow. In the same year two immature Gulls, of this size, were seen over the Isis at Sandford on the I $9^{\text {th }}$ June (A. H. Macpherson in lit.), a rather unusual time of the year for them to visit us. Other specimens have been procured in the Cherwell valley, near Banbury, and in the neighbourhood of Oxford.

\section{THE GREAT BLACK-BACKED GULL.}

\section{Larus marimus.}

THe Great Black-backed Gull is an occasional visitor. The Messrs. Matthews wrote of it as often passing over Westonon-the-Green in small flocks of four or five (Zoologist, p. 2625), 
but it is much less common than the other Gulls already mentioned. An example, in immature dress, was shot by $\mathrm{Mr}$. George Jackson, then of Greenlands, near Henley, in that neighlbourhood, on the 3 I st December, I 849 (A. H. Cocks in lit.), and a very fine adult specimen, captured at Stanton Harcourt on the I2th August, I882, is preserved in Mr. Arnatt's collection. I have examined but one of these magnificent Gulls procured in the north of the county, an immature bird, which was shot in the Cherwell valley, two or three miles below Banbury, about the year I 866.

\section{THE ICELAND GULL.}

Lams lencopterus.

The Iceland Gull has occurred in Oxfordshire in one instance, viz. in the spring of 1836 , when a specimen, in the plumage of the first year, was shot on Port Meadow. This sperimen was in the Messrs. Matthews' collection. (Zoologist, p. 2625.)

\section{THE KITTIWAKE.}

Rissa tridactyla.

Tue Kittiwake is an oceasional, and not unemmon, visitor, firm autumn to spring, perhaps oceurring in winter more often than at other seasons. In spring I have known it shot here as late as the 24th March.

\section{THE POMATORHINE SKUA.}

Stercorarius pomatortimus.

Tre Pomatorhine Skua is an aecidental wanderer from the coast. The Messrs. Matthews record two specimens, in immature dress, procured in the vicinity of Oxford; one in February, 1834 , the other in November, I 848 . The first was then in the collection of the late Mr. H. E. Strickland. (Zoologist, p. 2625.) 


\section{THE ARCTIC, OR RICHARDSON'S, SKUA.}

Stercorarius crepidatus.

Ricinardsox's SkUA, an accidental wanderer from the coast, has occurred on several occasions. The Messrs. Matthews record that immature birds had frequently been killed in the neighbourhood, but they only knew of one instance of its occurrence in full plumage. This happened on the 2 ; th June, I837, when an adult bird, flying N.-E., passed over their heads within gunshot of the ground. (Zoologist, p. 2625.) A young one was shot near Chipping Norton on the 28th September, I84I (Annals and Magazine of Natural History, i $84^{2}$ ), and another on the Buckinghamshire borders, near Waterperry, in September, 1853 (Zoologist, p. 4I65). At Milcombe, near Bloxham, a very fine adult bird was shot on the 15th October, 1879 ; this was a straggler from the great host of Skuas which arrived on our coasts during the memorable immigration of these birds, which took place that antumn.

\section{THE FULMAR.}

\section{Fulmanus glacialis.}

The Fulmar has occurred, as a storm-driven wanderer, twice in Oxfordshire. On the 2oth February, I839, a male was found alive near. Weston Wood, and taken to the Messrs. Matthews, who had another in their possession which was shot on Port Meadow, in May, 1836 . (Zoologist, p. 262j.)

\section{THE MANX SHEARWATER.}

Puffinus anglorum.

The Manx Shearwater is an accidental visitor, storm-driven from the coast. One was taken alive at Chipping Norton in September, 1839 (Zoologist, p. 2625); a second, at the same place, in the winter of $1872-3(i b ., 1878, p .135)$; a third at Framington, in September, 1877 (ib., I878, p. 220); a fourth at Wroxton (ib., I879, P. 457); a fifth at Stratton Audley, at the end of August or beginning of September, 1885 ; and a sixth at Cornwell in August, I887 (W. W. F.). 


\section{THE FORK-TAILED PETREL.}

Cymochorea leucorrhoa.

Tin Fork-tailed, or Leach's, Petrel, has wandered to this county on many occasions, being blown inland by storms. The following instances are on record:-One found dead in a turnip-field near Chipping Norton, I6th December, I8 3 I (Loudon's Magazine of Natural History, I832, p. 282). One found dead, in February, I838, at Weston-on-the-Green, where others have been picked up in a similar condition; one shot at Henley in 1847 (Zoologist, p. 2625). One found dead in Blenheim Park, in the winter of 1850-1, preserved in the Ashmolean Museum (ib., p. 3 3 I 8 ). One at the same place, November, 1859 (it., p. 6780). One picked up dead at Lower Heyford, early in December, I88I; many of these birds visited the English coast about that time, and this example was probably blown inland by the storm which oceurred at the end of November. As will be observed, most of the Petrels procured here had perished from exhaustion.

A specimen procured at Standlake, some twenty years ago, is preserved at Burford; and there ras an example in the collection of the late Mr. W. Phillips, of Salford, to which the marginal note, Chipping Norton Common, 1858 , in a marked printed list of British Birds with the collection, probably had reference.

\section{THE STORM PETREL.}

Procellaria pelagica.

The Storm Petrel is a wanderer, driven inland by bad weather. Lewin, at the end of the last century, mentions the occurrence of one at Oxford (Birls of Great Britain). Two were shot, from a little party of five, at Eynsham, in December, 1837 , and another was procured at Chipping Norton, in November, 1846 (Zuologist, 2625). The Rev. 
F. O. Morris mentions the occurrence of three near Chipping Norton (History of British Birls, vol. viii), and examples have been obtained in recent years at Headington, and on the Isis above Oxford, where one flew into Bossom's barge in bad weather (H. A. Macpherson, MIS.). The Storm Petrel has also occurred in the north of the county, near Banbury.

\section{THE RAZOR-BILI.}

Alcre torda.

The Razor-bill is an accidental wanderer from the coast. It has been procured on the Isis at Oxford in April, I 853 (Zoologist, p. 3946), on Clattercote Reservoir in December, 1878 , and at Nuneham (E. W. Harcourt, MS.).

\section{THE COMMON GUILLEMOT.}

Uria troile.

The Common Guillemot is an accidental wanderer from the coast. An example was shot on the Isis at Sandford in October, I 840 (Zoologist, p. 2623), and another was caught on a night-line set in the Cherwell, near Somerton, some years ago.

\section{THE LITTLE AUK.}

Mergulus alle.

The Little Auk is an accidental wanderer from the coast, generally after bad weather. The Messrs. Matthews record that several examples have been caught alive, the last of them being captured, in an exhausted condition, in Christ Church Meadow, in November, 1845 (Zoologist, p. 2623). Another was taken at Salford in December, 1847 (Morris, Mistory of British Birds, vol. vii), and Messrs. H. A. Macpherson and J. R. Earle found in a local collection belonging to a ratcatcher, at Clifton Hampden, a specimen of the Little Auk, shot in 1872 . 


\section{THE PUFEIN.}

\section{Fratercula arctica.}

The Puffin is an accidental wanderer from the coast. One was caught alive at Tackley, near Woodstock, on the 22nd November, I882, and sent to Mr. W. C. Darbey, of Oxford. who informed me that it was apparently not much exhausted by its flight. Another, described as a Little Auk, but, from the description given, evidently of this species, was recorded in the Leafield. Purish Magazine, for January, I883, to have been picked up by the road side at Fairspear, about the end of the same month. These two birds doubtless came inland together. An immature bird, with bill imperfectly developed, was taken alive at Fencot in Otmoor on October 9, I888, and was bought in the Oxford market by Mr. - Lambert (W. W. Fowler, MIS.).

\section{THE GREAT NORTHERN DIVER.}

Colymbus glacialis.

The Great Northern Diver, a casual visitor, has occurred in some half-dozen instances. The Messrs. Matthews reeord an immature specimen found in a garden on Headington Hill, Oxford, one morning after a remarkably stormy night in October, I824, which was kept alive at the Anatomy School during six weeks, and afterwards preserved there, the particulars of which were communicated to them by Dr. Kidd, the Regius Professor of Anatomy; also one shot at King's Weir, Oxford, in 1845 , and another on the Thames at Whitchurch (Pangbourne), in I794 (Zoologist, p. 2540). An example in the University Museum is labelled 'Cassington, 1828 ,' and another shot on the pond at Wroxton Abbey is preserved there. An immature bird, in the possession of a fisherman at Standlake, was shot on the Isis a few years before 1883 (W. H. Warner, MS.). 


\section{THE BLACK-THROATED DIVER.}

Colymbus arcticus.

THE Black-throated Diver is a casual visitor of rare occurrence. Dr. Kirtland informed the Messrs. Matthews of one, in immature plumage, shot near Cassington in the winter of I 828 (Zoologist, p. 2540), which, however, may have been the Northern Diver preserved in the Museum; and an entry in Mr. T. Beesley's note-book, under the date 3 Ist January, I 849, refers to another in the same dress shot on Clattercote Reservoir. A third was shot in January, I877, on the Cherwell, near Banbury, by a boatman named Hunt (C. M. Prior, Zoologist, I877).

\section{THE RED-THROATED DIVER.}

Colymbus septentrionalis.

THE Red-throated Diver is a casual visitor. In the neighbourhood of Weston-on-the-Green, according to the Messrs. Matthews, it was occasionally found during the winter (Zoologist, p. 2540). There is an example in the Museum, procured at Sandford in 1828 , and one was shot on the Thames below Henley, on the 9th February, I848, by Mr. G. Jackson (A. H. Cocks in lit.). The Red-throated Diver has also occurred at Over Norton (W. Wyatt). The last occasion on which it has been obtained was in March, 1888, when two were shot at Oxford, one on the river near the railway station, and the other near the mouth of the Cherwell; the latter, which I saw at Mr. Darbey's, was an adult in winter dress.

\section{THE GREAT CRESTED GREBE。}

Podiceps cristatus.

The Great Crested Grebe is a resident, from early spring until late autumn, on Clattercote Reservoir, where two pairs have bred for several years past. Even in the mildest seasons they do not pass the winter there; I have never seen them in 
autumn later than the I8th November, and they have usually departed before October is out. The return in spring depends upon the state of the weather; in I884 I observed a pair on the I 2 th February, but in I 886 they were delayed by the severe frost until the 28th March, the ice having broken up only a week before.

The time of nesting consequently varies in different years; for instance, in the two years just named, young birds onethird gromn were on the water by the I 9 th June in the former, while in the latter they were no further advanced nearly a month later. In 1883 again, after severe weather in Mareh, the young were but newly hatched by the middle of July.

The Crested Grebe is said to lay four eggs, but I have never known more than three young in a brood on Clattercote, sometimes only two; neither has the Rev. II. Holbech seen more than three there.

On the I 5 th July, I 883 , I watched an old Grebe, in a thim bed of rushes, carrying her young on her back, some portion of her wings (the secondaries or tertials probably) being slightly raised, forming a sort of cradle. Four days later both old birds had the young out on the open water, evidently giving them an early swimming lesson. When first noticed the young lirds were on the water between the old ones; one of the latter presently, sinking itself low in the water, came up under them, and so took them on to its back, then sinking again, moved away sideways, and left them floating on the surface; this was repeated several times until, taking the alarm, the old ones carried the brood off to the thick rushes.

The guttural note of the adults, often uttered when they are alarmed, is monosyllabic, and very difficult to describe; in 'Yarrell' it is called a croak. The young have a loud, shrill piping cry, which they utter constantly when following their parents for food. The Grebes (especially the hen bird when she comes off the nest) often indulge in an exhaustive wash, dipping and shaking their heads beneath the surface of the 
water, and splashing with their wings and feet in evident enjoyment. I have frequently seen them take wing, without any apparent difficulty, and fly for a considerable distance, an elevation of five or ten feet being occasionally, but rarely, attained.

The adult birds on their appearance in spring are in full nuptial plumage, with glossy blackish-brown erests, and rich chestnut tipped ruffs. By the 26th September they were far advanced towards winter dress, hardly a sign of the chestnut showing, and by the r6th October the winter plumage was fully assumed, the dark crests, retained at that season, contrasting with the plain white faces and greyer body tints than those worn in summer. The young in down have the face and neck streaked with longitudinal dark lines, which are retained until they are full grown, disappearing gradually in autumn.

On the 28th April, I884, there were two Grebes on the water, which had but very slight erests and no facial ruffs, heads and backs dusky, neck and underparts of a less pure white than in the adults; they did not remain here, and this is the only occasion on which I have known immature birds to appear in spring, those that arrive to breed being invariably in the adult stage of plumage, although the bright colours are not always fully developed when their arrival takes place at an early date.

About the end of July, I 888, four Great Crested Grebes were said to have been killed among the rushes in the Cherwell at Stone-bridge, about two miles above Banbury, by some men who were mowing the hay-grass; the river is there rather sluggish, and choked up with rushes. I examined one of these birds, which was an adult in full breeding dress, and it seems probable that they were two breeding pairs whose young escaped observation.

The Great Crested Grebe occasionally appears on the Thames in winter, and the Messrs. Matthews write of it as 
sometimes found in their neighbourhood. On the 7 th March, I886, a specimen, in nuptial dress, probably on its way to its breeding haunts, was shot on the Isis at Sandford (A. H. Macpherson); another was obtained close to Oxford in March, I 888.

The Great Crested Grebe also breeds annually upon Wormleighton Reservoir, about two miles from Clattercote, and only just over the Warwickshire borders.

A note on the breeding and habits of this bird will be found in the Midland Naturalist for I882, p. 275.

\section{THE RED-NECKED GREBE.}

Podiceps griseigena.

The Red-necked Grebe is an occasional winter visitor of rare occurrence, wandering inland, in England, less frequently than either of the two species next to be mentioned. In November, 1881, an example procured at Oxford was taken to Mr. Darbey (H. A. Macpherson, ILS.), and Mr. Prior records une shot on one of the canal feeders near Banbury (Banbury Gucrdian). It is included in the History of Bantury list as 'an occasional visitant, very rare,' on the authority of Mr. Abbott.

\section{THE SCLAVONIAN GREBE.}

Podiceps auritus.

The Sclavonian, or Dusky, Grebe is an occasional visitor. The Messrs. Matthews record that several have been killed near Oxford, in winter dress (Zoologist, p. 2623). Mr. Arnatt has a specimen in this plumage which was shot on the Isis, at Stanton Harcourt, and another was procured on the Cherwell, at Islip, in March, I888. 


\section{THE EARED GREBE.}

Podiceps nigricollis.

The Eared Grebe is an occasional visitor. The Messrs. Matthews record that a specimen in full summer plumage was shot on the Isis, near Sandford, in June, 1847, and that it has also been procured in the winter months. The Rev. H. A. Macpherson, in I882, found an Eared Grebe in a local collection at Clifton Hampden. Mr. Prior records one of these birds procured on the Cherwell in the north of the county. (Banbury Guardian.)

\section{THE IITTLE GREBE.}

Podiceps fluviatilis.

The Little Grebe, or Dabchick, is a resident in some numbers, breeding on most of the reedy ponds and larger sheets of water which afford it sufficient cover, and in suitable places along the Isis, and other rivers, where it is fond of haunting the mouths of the back-brooks and larger overgromn ditches.

The powers of flight of the Little Grebe, said by some authors to be limited, can be studied to advantage at Clattercote Reservoir, where, not only in spring, but at other seasons, these little divers may often be seen to rise from the water, and fly for a considerable distance on rapidly-beating wings.

In the case of a shy bird like the present, opportunities of observing it at close quarters are seldom enjoyed, and the following note by the late Rev. T. W. Falcon will be read with interest. 'Water Rails and Dabchicks frequent our very sluggish river Ray; I have often watched the latter feeding her young. The latter swim about in shelter of thick flags, and the mother dives after the fry, I think, of roach, and having caught one, pokes no more than her head above water, gives it to one of her brood, and slips under again silently' (in lit.). 


\section{THE COMMON CORMORANT.}

Phalacrocorax carbo.

The Cormorant is a rare occasional wanderer from the coast, long ago noticed by Plot, who writes, - ' As for birds that have casually flown hither, or come but at certain seasons of the year, by naturalists stiled Aves migratorice, besides Swallors, and some well known winter fowl; The Cormorant has been observed to come hither about Harrest time, whereof there was one killed from St. Marie's steeple (tired with a long flight), An. I675, and another young one taken up in Arncot-field fallen down in the com, and brought me to Oxford.' (Natural Ilistory of Orfortshire.) It has been remarked that when the Cormorant and the Shag, the next species to be treated of, come inland, they often settle upon elevated positions, such as church towers, tall chimneys, and the like, situations most resembling their native rocks; thus a correspondent of the Field. (23rid November, I 880), mentions a Cormorant seen, during a snowstorm, sitting on the steeple of Wheatley Church. Examples have been shot on the water in Kirtlington Park, in December, I 845 (Zootogist, p. 2624); at Ridge's Weir, on the Isis above Newbridge, many years ago (Warner IIS.); and on Clattercote Reservoir, on the 7 th Norember, 1879 .

\section{THE SHAG, OR GREEN CORMORANT.}

Phalacrocorax graculus.

The Shag is an accidental visitor from the coast, from which it seldom wanders. One was shot on the Isis a few years before 1849 (Zoologist, 2624), and another near Oxford, which was afterwards presented to the Ashmolean Museum (il. 3I I 8 ). In December, x 880, a Shag was shot while sitting on the ridge of a barn roof at Souldern. 


\section{THE GANNET.}

Sula bassana.

The Gannet, or Solan Goose, is an accidental visitor from the coast. An adult bird was seen passing over Weston-onthe-Green, on the 14 th October, 1838 , and it is stated by the Messrs. Matthews to have been met with also on other occasions. (Zoologist, p. 2624.) Mr. C. E. Ruck-Keene has a Gannet, which was shot at Oxford in $18+3$. Mr. Beesley has furnished me with the following extract from the Bunbury Guardian, entered in lis note-book for the 25 th February, I 845. 'A flock of Gannets passed over the town-one found next morning.' I am informed that another, in the dark immature plumage, was shot in the Cherwell meadows, near Banbury, in 1877 .

\section{THE HERON.}

\section{Ardea cinerea.}

The Heron is a resident, breeding in a few spots only. In Tar Wood, the property of Mr. E. W. Harcourt, near Stanton. Harcourt, there is an old-established heronry. Mr. Harcourt informs me that he has known it all his life, and that his grandfather (who I believe was born about the year I757) told him that it had always existed. During Mr. Harcourt's own knowledge of Tar Wood the nests have varied from thirty to sixty annually. When I visited the wood in April, I 888, I learned with regret that the Herons, which had been much disturbed, and, notwithstanding Mr. Harcourt's endeavours, had been considerably shot down at their feedinggrounds, were not breeding that season, nor had they done so for the last two years, although a few birds revisited the old nests a day or two previously. The woodman told me that in I 88I or 1882 he counted as many as twenty-six occupied nests, and it is confidently hoped that the Herons may return to breed another year. The nests which I saw were placed in the small branches of rather low oak trees, not more than 
thirty or forty feet from the ground. There is a small heronry, occupied at the present time, in some trees at Friar's Court, Clanfield (J. W. B. Bell in lit.), while Herons have been known to breed casually in other localities. Mr. H. Gale informed Mr. Harcourt (in 1887) that, two years before, a Heron's nest was pointed out to him at Waterperry, and he had been told that they nested at Rycote. In the autumn of I886, I saw a Heron's nest in one of a row of trees in the meadows at the junction of the Sorbrook and the Cherrell, near Adderbury, where one or two birds may generally be seen. The tenant of the land said a pair of Herons built it just before the meadows were mown, but, being disturbed by the haymakers, they left it, returning when the fields were quiet again. I do not think any young were hatched, and as these birds usually breed very early in the year (having eggs sometimes in the third week in February), the ocenrrence must be considered abnormal. Nost of the Herons so commonly seen upon Port Meadow, Oxford, are drawn from the colony in the Wytham Woods, on the Berkshire banks of the river, while those seen about Henley have their home at Harleyford, about four miles from the Oxfordshire borders, where they have bred for many years in a clump of Scotch firs. (A. H. Cocks in lit.)

The Heron is a pretty constant visitor to all our river valleys, being often seen in the north of the county, even in summer, and especially at night at that season. In winter they are always to be found in the Cherwell valley, often four or five together, and on the 26th November, I882, I saw as many as eleven rise together from a flooded meadow at Nell Bridge, near Adderbury.

\section{THE PURPLE HFRON.}

Ardea purpurea.

The Purple Heron has oceurred in three instances. Mr. T. Goatley informed the Messrs. Matthews of one shot some 
years previously, near Witney, and they mention another shot on Otmoor in the winter of 1837 (Zoologist, p. 2600). The latter example passed into the collection of the late Mr. E. H. Rodd, of Penzance, and is now in the possession of Mr. W. H. Vingoe, of that town, who had it in exchange from Mr. Rodd, as it was not a Cornish specimen. It is in immature plumage (W. H. Vingoe in lit.). Some five-and-twenty, or thirty years ago, an adult Purple Heron, handled while in the flesh by MIr. G. Arnatt, was shot on the Isis between Eynsham Bridge and Bablock Hithe; it was preserved, but afterwards was destroyed by moth.

\section{THE GREAT WHITE HERON.}

Ardea alba.

Tre Great White Heron, an accidental visitor from Southern Europe, Asia, and North Africa, has once visited this county. Mr. Frederick Holme sent Mr. Yarrell the measurements of a specimen which was shot on the Isis, not far from Oxford, in September, I 833 (History of British Birls, 4th edition, vol.iv), and the Messrs. Matthews also received notice of the fact from the Rev. H. Roundell.

\section{THE NIGHT HERON.}

Nycticorax griseus.

Tre Night Heron is an occasional visitor of rare occurrence. First recorded as a British bird by Latham, in his Synopsis, from a specimen procured near London in 1782 , it was only a few years later that a second example (in this case in the spotted dress of the immature bird) was procured in Oxfordshire, the particulars of which were communicated to the Linnean Society, 3rd April, 1798. On the authority of this specimen, Montagu included in the British list the 'Gardenian Heron,' by which name the young of the Night Heron was then known. It was shot by Lord Kirkwall, near Thame, as it sat on a tree, to which it had retired probably after feeding 
by the side of the adjacent river Thame. (Omithological Dictionary, 1802, and Supplement, I813.) In I833 a specimen was shot near Wootton and passed into the Ashmolean Museum; another, procured near Standlake in the spring of 1835, formed part of the Messrs. Matthews' collection (Zoologist, p. 2600.) An adult bird, now preserved at a house in Bampton, was shot there by its owner's father many year's ago. (Rev. J. W. B. Bell in lit.)

\section{THE LITTLE BITTERN.}

Ardetta minuta.

The Little Bittern is an occasional visitor. A female was shot on Otmoor in 1827 , another example on the Cherwell, and a fine specimen near Bampton in 1847 (Znolugist, p. 2601). On Otmoor a Little Bittern was shot by F. Goom, and brought in the flesh to Smith, the bird-stuffer, in St. Clement's, Oxford, in I 872. After passing through several hands, it was in $\mathrm{I}_{882}$ in the jossession of Mr. Pearee, of Blackfriars Road, Oxford (H. A. Macpherson in lit.). One in immature dress, which was shot on the 27 th October, I 867, on the Cherwell, a little way below Banbury, is now preserved in that town, and Mr. IV. Newton, jun., informs me that another, procured at Bensington some years ago, is in their collection (in lit.).

On the Berkshire side of the 'Thames, at Wargrave, a Little Bittern was knocked down with a punt pole, while sleeping on the banks of a pond, on the $4^{\text {th }}$ May, I867. (Zoologist, ss. p. 829.)

\section{THE COMMON BITTERN.}

Botamus stellaris.

The Bittern was formerly a not uncommon bird in Oxfordshire, resident probably on Otmoor and in the low swampy country which at one time bordered the upper reaches of the Isis. Writing, in I 849 , the Messrs. Matthervs remark,-'In the Bittern we have another instance of the gradual dis- 
appearance of a race once well known in this part of the world.' They mention specimens procured at Fringford, Stanton Harcourt, Otmoor, and W'eston-on-the-Green, where they themselves captured a second on the 9th January, I 849 , a female being shot at Bletchington a few days after. (Zoologist, p. 2600.) At the present day the Bittern is only an occasional visitor during the winter months. The following instances of its occurrence may also be enumerated. One in the University Museum labelled Eynsham; one at Clattercote Reservoir, I 7 th December, I8+7 (T. Beesley, IIS.); one at Cropredy; one on the Cherwell near Banbury, I 860 (W. Wyatt); one at Standlake, twenty years ago, now preserved at Burford; one near Fencot, on Otmoor, $55^{\text {th }}$ December, 1878 (T. W. Falcon in lit.); one at Cote, near

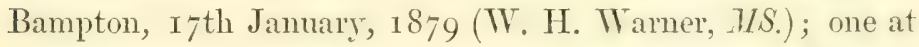
Stadhampton, November, I879; and one, a male, at Merton, near Bicester, 3rd February, i886 (A. H. Macpherson in lit.).

A long and interesting note on the Bittern in Oxfordshire, from the pen of the Rev. A. Matthers, will be found in the Zoologist for I88I (p. 462).

\section{THE WHITE STORK.}

Ciconia alba.

TuE White Stork is a casual visitor. In the spring of 1828 four were seen on Otmoor, one of which was killed and taken to Mr. Forrest, of Oxford, for preservation; the other three escaped (Zoologist, p. 260I).

\section{THE BIACK STORK.}

Ciconia nigra.

THE Black Stork is an accidental visitor. On the $5^{\text {th }}$ August, I865, a specimen in immature dress was shot by F. Goom, a wildfowler, of Charlton-on-Otmoor, close to that place, and is now in the possession of Mr. G. R. Castle, of Bicester. 
This example is recorded by Gould in his Birds of Great Britain, where the date is mis-stated as November, I862, and by Mr. C. M. Prior in the Zoologist for 1877 (quoted in Yarrell's History of British Birds, ath edition, vol. iv, p. 226), where the locality is mis-spelt as Osmoor.

\section{THE GLOSSY IBIS.}

Plegadis falcinellus.

The Glossy Ibis is an accidental visitor. Dr. Lamb writes : 'A male of this very rare bird was shot a few miles from Reading in September, r793, while flying over the Thames in company with another, and were supposed to be Bitterns. Having sent the description of the bird to our celebrated naturalist, Mr. Sowerby, F.L.S., who has favoured the world with it, accompanied with a coloured drawing, in his British Miscellany, table xvii, p. 35, I must refer the Society to that work.' (Ornithologia Bercheria.) This bird, then in the possession of Dr. Lamb, is stated by Montagu to have been shot between Henley and Reading, and to have been intermediate between the fully adult and transitional stages of plumage, then known as the Bay and Glossy Ibises; the young bird being styled the Green Ibis. (Omithological Dictionary: Supplement.)

\section{THE GREY LAG GOOSE.}

Anser cinereus.

The Grey Lag is the true Wild Goose, formerly resident in the English fens, where, however, it has ceased to breed for the last hundred years. It is now a very rare visitor to any part of Southern Britain, being less migratory in its habits than some of its congeners.

Considerable mystery enshrouds the Grey Wild Geese which visit Oxon from the fact that specimens are so rarely shot. The Messrs. Matthews, when writing their account of our birls, took it for granted that this was the species 
which was 'always common in the winter months, and in some years unusually abundant' (Zoologist, p. 2622). In a subsequent volume of the same periodical, in reply to a suggestion of Mr. J. H. Gurney, they state that their note upon Anser ferus seemed more properly to refer to the Pinkfooted Goose (to be treated of presently). That the present species occurred in Oxon in former days is highly probable, but it must be confessed that the actual evidence of its occurrence is extremely slender. The Rev. A. Matthews, who is well acquainted with the appearance of the different species of grey geese upon the wing, when writing to me in 1887 , says that on one occasion he was near enough to fire at 'three very large Geese, with the unsatisfactory result of obtaining a few body feathers; these birds I believe were Grey Lags' (in lit.).

\section{THE WHITE-FRONTED GOOSE.}

Anser albifrons.

The White-fronted Goose is a winter visitor, appearing ' in small flocks, but is an uncertain visitor, and only found in the severest seasons' (Zoologist, p. 2538). The Rev. A. Matthews has recently informed me that he has often seen it brought into Oxford Market, and also, on the wing, large flocks of this ' easily recognised' species in the neighbourhood of Weston-on-the-Green. It is now of much more uncommon occurrence; the enclosure of Otmoor, so attractive to wildfowl in its open condition, doubtless causing a great decrease in the number of all kinds of Wild Geese visiting the county.

During a spell of severe weather in the early spring of 1888, a White-fronted Goose was shot from a flock of eight or nine at North Aston Mill. It is a very small bird, approaching A. erythropus in some points. The bill from the gape measures barely two inches; culmen (the ridge of which forms a straight line with the forehead), one and thirteen- 
sixteenths; tarsus, two and seven-sixteenths of an inch. The fact that the white on the forehead is broken, and does not extend to the eye by a quarter of an inch, may be accounted for by the bird not having assumed adult plumage, the breast being marked with a few dark spots only.

\section{THE BEAN GOOSE.}

Anser segetum.

Tre Bean Goose is a winter visitor, but, from the Messrs. Matthers' observations, would appear to be less frequent than the species next to be treated of, although from the difficulty of distinguishing the two species on the wing it cannot with certainty be determined to which the majority of the Wild Geese occurring in the county belong. That the Bean Goose has visited us is certain, from the fact that the Rev. A. Matthews has often seen it brought into Oxford Market, previous to his leaving Oxfordshire in I 854 (in lit.).

For the guidance of such as may be fortunate enough to examine any local specimens of Wild Geese, it may be well to state that in the Grey Lag and White-fronted Geese the 'nail' at the end of the beak is white, while in the Bean and Pink-footed Geese it is black; the last named is distinguished from the Bean Goose by its short beak, and characteristically coloured feet, which in the latter species are orange.

A note in Mr. G. Jackson's copy of Bewick relates to a Bean Goose shot by him on the 24th January, I850, when living at Greenlands, Henley-on-Thames.

\section{THE PINK-FOOTED GOOSE.}

Anser brachyrhynchus.

The Pink-footed Goose is a winter visitor, and it is believed by many ornithologists that to this species belong the majority of the flocks of Wild Geese which visit England in winter. As previously stated, the Messrs. Matthers considered that 
their note upon the Goose which was 'always common during the winter months, and in some years unusually abundant,' referred more properly to the present species, which, they add, 'we have every reason to believe is the most abundant of the two' (Zoologist, p. 2736). The Rev. A. Matthews often saw the Pink-footed Goose in Oxford Market previous to 1854 . With regard to the north of the county, Grey Geese of some kind are occasional visitors to our water-meadorws, and fields of young corn, in the winter months, while at that season a 'skein' of them passing high overhead is not a very uncommon sight, their sonorous 'honk, honk, honk,' falling gratefully on the ear of the sportsman-naturalist. I have only once been able to examine a specimen killed in the district, which proved to be a White-fronted Goose, although on the Igth February, I88I, in the Sorbrook meadows, near Adderbury, I unsuccessfully pursued a flock of sixteen for' some hours, without getting a shot, the whole 'gaggle' rising in the first instance from a partly-flooded meadorw, at not more than a hundred and fifty paces distance.

\section{THE BERNICLE GOOSE.}

Bernicla Teucopsis.

The Bernicle Goose is included by the Messrs. Matthews in their list as an infrequent visitor, and Mr. C. E. Ruck-Keene, of Swyncombe House, has a specimen which was shot at Henley. This and the following species are known to gunners as 'Black Geese,' and are more attached to the coast than the 'Grey Geese' before treated of, seldom wandering inland.

\section{THE BRENT GOOSE.}

Bernicle brenta.

The Brent Goose is also included by the Messrs. Matthews as an infrequent visitor. Three were killed at one shot on the Thames, near Henley, by Mr. George Jackson, who has one preserved (A. H. Cocks in lit.), and it has occurred so recently 
as January, I 888, when a fine example of the dark-bellied race was shot at Standlake, about the middle of the month, after a week of thick foggy weather; it was taken to $\mathrm{Mr}$. Darbey for preservation, and while in his hands was examined in the flesh by Mr. A. H. Macpherson.

\section{THE CANADA GOOSE.}

Bemicla canadensis.

The Canada Goose, a native of North America, has been kept in a semi-domesticated condition in England for the last two hundred years, and it is probable that all the numerous examples procured in an apparently wild state are, at the most, descendants of naturalized birds; but since Yarrell considered it entitled to a place in his work (an opinion not, however, shared by the editor of the last edition), there seems no reason to exclude it entirely from the catalogue of Oxfordshire birds. After all is said against the propriety of its inclusion among the British avifauna, it must be allowed that it stands now on a very similar footing to the Pheasant.

The several occurrences of this fine goose in Oxfordshire are therefore here enumerated for what they are worth. In February, 1838 , a male was shot on Port Meadow, and in the winter of 1845 another was killed on Otmoor (Zoologist, p. 2538). There is a specimen in the University Museum, labelled 'Islip, I845,' while another, shot many years ago, in the Cherwell meadorvs below Banbury, is now preserved in that town. With regard to the latest occurrence of Canada Geese in Oxfordshire, there can be no doubt of their semidomesticated origin; on this occasion, as he late Rev. T. W. Falcon wrote me word, thirty-two appeared on Otmoor in the severe frost of I 878-9. He writes,- - They were not truly wild, and my unconscionable neighbours secured twenty-eight of them. The survivors are now wild enough.' The heaviest of these weighed fourteen pounds. 


\section{THE EGYPTIAN GOOSE.}

Chenalopex aegyptiacus.

The Egyptian Goose is another species, the presence of which in a truly wild state in Great Britain is open to considerable doubt. As in the case of the Canada Goose, the example set by Yarrell in including it is here followed. Mr. Roundell gave the Messrs. Matthews information of one shot on a large piece of water at Shelswell, as far back as 1822, and the same writers mentioned an example shot by the Duke of Marlborough's gamekeeper, on the lake at Blenheim, in December, 1847. Two which were shot at Cowley, in the middle of June, I 886, were taken to Mr. Darbey, who informs me that he could find no marks of confinement on them, nor could he hear of any being missing from ornamental water about that time; the season at which they were procured, however, almost precludes any opinion other than that they were escaped birds, while other examples brought to him since then exhibited unmistakable signs of captivity.

\section{THE WHOOPER.}

Cygnus musicus.

The Whooper, or Whistling Swan, is a rare winter visitor. ' In the severe winter of $1837-8$ great numbers of Wild Swans visited this part of the kingdom. On the morning of the 6th February a flock of fifteen made a descent upon the kitchen garden of these premises [Weston-on-the-Green], evidently with the intention of attacking a bed of cabbages, from which the snow had been thawed. They did not however settle, but continued to wheel round the spot for some minutes, until a shot was fired which severely wounded one of them;' the wounded bird was captured at no great distance. (Matthews, Zoologist, p. 2538.) In October, 1871, a young bird of this species, shot on the Isis out of a flock of seven, was shown to Mr. W. H. Warner at the Trout Inn, Tadpole, near 
Bampton. On the 21st February, I 864, four Wild Swans were seen at Fawley, Bucks, flying westward over the Chiltern Hills. (Birds of Berlis and Bucks, p. I 20.) Fawley is only about half a mile over the county boundary, and the direction of the birds' flight would take them into Oxfordshire in a few minutes.

\section{BEWICK'S SWAN.}

Cygnus bewicki.

Bewick's SwAx is also a winter visitor to England in severe weather, but is rarer than the Whooper. In the winter of I $837-8$, in which so many Wild Swans visited this county, two examples of this species were shot near Oxford. (Zoologist, p. 2539.)

\section{THE MUTE SWAN.}

Cygnus olor.

The Mute $\mathrm{S}$ wan is found in a semi-domesticated state on the 'Thames and the larger sheets of water in the county, wften wandering in winter along the streams to a distance from their usual haunts. There is some reason to believe, however, that really wild birds, migrants to our shores from Eastern Europe, have occurred here. The Messrs. Matthews wrote, 'several instances of the Mute Swan in an apparently wild state, also occurred during that season [ $1837-8]$; these, it is true, might have been tame birds, which had forsaken their usual haunts, to join the wandering bands of their allies; be this as it may, in their habits they altogether differed from the really tame swans, which often visit us in parties of three and four during the spring.' (Zoologist, p. 2539.) On the $3^{\text {rd }}$ February, 1884 , I observed a Swan (identified as of this species, with the aid of a glass) on Clattereote Reservoir, which had every appearance of a truly wild bird; it would not admit of an approach, and, on my following it to the lower end of the water, rose on the wing and flew away. The fact of this bird flying of course proves nothing, as it is not unusual for 
the most domesticated Swans to do so, but the ease with which this bird rose, together with its great shyness, and vigilant, wary disposition, all pointed to its being a wild bird.

'In England the Swan is said to be a bird royal, in which no subject can have property when at large in a public river or creek, except by grant from the erown. In creating this privilege the crown grants a Swan-mark.' (Yarrell.) The same author gives a representation of the Swan-mark used by the Corporation of the City of Oxford, taken from a rare tract on Swans and Swan-marks, printed in 1632, and writes, 'The city of Oxford has a game of Swans by prescription ; and in the sixteenth century, when a state dinner was not complete unless a Swan was included in the bill of fare, the game of Swans was rented upon an engagement to deliver yearly four fat Swans, and to leave six old ones at the end of the term. By the Corporation books it also appears that in I 557 barley was provided for the young birds at fourteen pence a bushell, and that tithes were then paid of Swans.' (History of British Birds, $4^{\text {th }}$ edit., vol. iv.)

By the kind permission of the proprietors of the above work, I am enabled to reproduce here the representation of the Corporation Swan-mark.

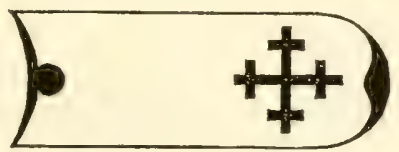

In a report made in 1854 by Mr. Hester, the then Town Clerk of Oxford, the following entries occur. 'The City had anciently a Game of Swans, respecting which there are many entries in the old books. The Swans seem to have been fed during the winter, and to have had nests in Christ Church Meadow and other places.... Messrs. Hall and Tawney's Brewery stands on an island called Swan's nest, and within living memory the proprietors of the brewery kept up the 
breed of Swans.' The Brewery is now known as the Swan Brewery, and there is a public-house called 'The Swan' close by and verging on the river; there is also a small City property named Swan Island. Mr. I. J. Bickerton, the present Town Clerk, to whom I am indebted for these particulars, kindly informs me that no customs are now kept up in connecnection with the Swans.

\section{THE RUDDY SHELDRAKE.}

Tadorna casarca.

Tie Ruddy Sheldrake is a rare accidental visitor to England from South-Eastern Europe, and North Africa. Mr. J. E. Kelsall informs me that he saw, in a small bird-stuffer's house in Oxford, an example which was shot on Port Meadow on the 3 rd Mareh, 1885.

\section{THE SHELDRAKE.}

Tadoma comuta.

The Sheldrake is a rare visitor from the coast. The Messrs. Matthews write,-_We seldom pass through the winter without a visit from this fine bird.' (Zoologist, p. 2539.) In the winter of 1880 , it was stated, in a local paper, that a Sheldrake was shot at Hook Norton, and a male was procured on Port Meadow on the 24th January, I885 (J. E. Kelsall in lit.).

\section{THE MALLARD OR WILD DUCK.}

Anas boscas.

Tне Wild Duck is a resident, breeding in some numbers on the larger sheets of water, as, for instance, Clattercote Reservoir and the lake at Blenheim, and sparingly along all our rivers and streams, where the nest is often placed in the head of an old pollard willow; nor is it essential that the stream should be of any size, for I once surprised a young brood in the brook which runs between Great Bourton and Hanwell, and is there not more than four or five feet wide, 
but thickly grown up with bur-reeds and flags. In May, I879, I saw a Wild Duck fly from her nest in the fork of a beech tree, in Blenheim Park, fully twelve feet from the ground, the tree being at least a couple of yards from the bank of the lake. Since the successive passing of the Wildfowl and Wild Birds Preservation Acts, which have gradually become effective, the number of Wild Ducks breeding in the county at large has considerably increased.

In winter large numbers of Wild Ducks often arrive in the county, especially when the valleys are flooded; and 'flighting,' or shooting the ducks as they fly from the sheets of water where they have passed the day, to their feedinggrounds at night, may then be practised with some success. The ducks leave the water where they have rested in security during the day a little after sunset, and after much noisy quacking wing their way to the feeding-grounds, returning soon after it is light in the morning. Early in the season the fields where the barley is still uncarried, and the wheat stubbles, are visited by the home-bred birds, and in winter, after the arrival of the migrants, the smaller streams, and especially the wet meadows, are resorted to, especially if there should be large floods in some parts of the valley, at which time thousands of ducks may sometimes be seen. On the deeper floods the birds sit out on the water all day, secure from all attacks, making their way at evening to feed on those meadows which are only slightly covered with water. These larger flocks are migrants from a distance, though not necessarily from abroad. In some winters, however, ducks are killed which can readily be distinguished from our home-bred birds. Slightly smaller and neater in appearance, the Mallards are brighter in plumage, with the colours purer and more clearly defined, the legs and feet almost vermilion colour; the ducks are darker in colour, with more distinctly spotted underparts. A drake of this kind, in fine condition, will weigh two pounds ten ounces, and a duck half-a-pound 
less. Yarrell gives the weight of a Mallard as up to three pounds and a half, and many ducks will weigh two pounds and a half. Although the difference between these smaller ducks and our home-bred birds is slight upon comparison, it is easily seen when the birds are freshly killed, and the former are, I believe, well known to dealers as 'foreign fowl.'

On Otmoor wildfowl were formerly so abundant as to enable certain men to gain their livelihood by shooting in winter, and some such are still living in Charlton-on-Otmoor; but the winter shooting has greatly fallen off there, and the same may be said of the Cherwell valley. In the latter case this is due in a great measure to the better drainage of the meadows, and to the cleaning out of the bed of the river, which enables the water to get away more quickly, the floods running off very rapidly in consequence.

On the I 2 th September, I 885 , I saw a nearly white variety of the Wild Duck on Clattercote Reservoir; his brilliant yellow bill, seen through the glass, suggested a cross with some domestic variety, or with the 'call' duck. When shooting at Adderbury, near Nell Bridge, on the $4^{\text {th }}$ October, 1884, we bagged a curious light buff variety, a duck, which I described in the Zoologist (1885, p. 30). I have on more than one occasion scen a precisely similar variety among domesticated birds.

\section{THE GADWALL.}

Anas strepera.

The Gadwall is a rare visitor. In January, 1833 , the Messrs. Matthews obtained a male, and in the following. winter a female, both of which were shot near Standlake, and they stated that it had also been met with in other parts of the county (Zoologist, p. 2539). Mr. C. E. RuckKeene has a Gadwall which was shot at Henley-on-Thames some years ago (in lit.). 


\section{THE SHOVELLER.}

Spatula clypeata.

Tue Shoveller, which breeds in some parts of England, is an occasional visitor to Oxfordshire, but there is no evidence of its having remained to nest in the county. The late Rev. T. W. Falcon, however, believed that a pair, the male of which was shot on Otmoor in the spring of 1880 , intended to breed there. He writes,- 'The man who shot the Shoveller professes not to remember the date. He thinks it was in March, or says so; I fancy it was later and in close time' (in lit.). The same man shot a bird of the year in the same place in the October following.

The Messrs. Matthews stated that a few specimens were generally killed during the season (Zoologist, p. 2539). Upon Otmoor, whence Mr. A. H. Macpherson received a drake shot on the I 2 th November, I 886, the Shoveller is a well-known winter visitor (T. W. Falcon in lit.); while on the upper Isis, in the neighbourhood of Standlake, it occurs every winter (Warner, MS.). An adult male in the Oxford Museum is labelled 'Cassington.' It is naturally of less common occurrence in the north of the county, but a female was shot on the Cherwell, near Aynho station, in December, I88I, and I observed an immature bird upon Clattercote Reservoir, on the Ioth October, I 885 .

The local name for the Shoveller on Otmoor is 'Spoonbill,' and it is somewhat curious to remark that in the 16 th and I 7 th centuries the true Spoonbill (Platalea lencorotia) was known as the 'Shovellard' (vide Stat. 25 Henry VIII, cap. I I, and Zoologist, I877, p. 428).

\section{THE PINTAIL DUCK.}

Dafila acuta.

The Pintail is a scarce winter visitor to Otmoor and the Thames district. In the former locality, in recent years, one was shot in November, I880, another (one of three seen) 
on the r $4_{\text {th }}$ February, I88I (T. W. Falcon), also one or two in November of the same year (H. A. Macpherson, MS.); while in December, 1882 , a male sent up thence was hanging in Oxford Market. Mr. W. H. Warner informs me that a male was shot at Standlake, and there is a specimen in the University Museum labelled 'Sandford.' As late as the 3oth March in 1850 , a drake Pintail was shot near Henley, by $\mathrm{Mr}$. G. Jackson, of Greenlands (A. H. Cocks in lit.).

\section{THE TEAL.}

Querquedula crecca.

The Teal is best known as a winter visitor, but of late years it has remained to nest in two or three instances, and there is little doubt that with the protection now afforded to birds in the breeding-season it will be found to do so annually. On the 27th April, I874, the Otter hounds put up a male Teal from the Cherwell near Heyford (A. H. Cocks in lit.), while in the same month in I880, I found a pair in an osierbed at the point of junction of the Swere with the Cherwell. I have also seen the Teal on the upper Isis, near Eynsham, in April. In I 884, and the following year, young broods of Teal came under my notice in the first week of August on Clattercote Reservoir. Mr. Fowler has seen it in August at Kingham.

The winter visitors generally arrive in October, considerable numbers being sometimes seen on the flooded meadows, or wheeling over the water; occasionally as many as twenty or thirty in a 'spring,' or 'coil,' are seen, and I once counted sixty together on Clattercote Reservoir, on the 24th October, I 885 .

From their diminutive size, and habit of pitching down suddenly from a height with great rapidity, Teal are seldom shot at flight time, though they often splash down quite close to the gunner, who one moment hears their short sharp whistle in the air above him, and the next the harsh grating quack 
which is uttered on the water. The sportsman's best chance with Teal is in hard weather, when, wandering along streams, he sometimes comes upon a single bird in the still water of some quiet bend, from which it springs with the quickness and ease peculiar to these diminutive ducks.

\section{THE GARGANEY.}

Querquedula circia.

The Garganey is a visitor to this country on migration, remaining to breed in Norfolk, and is occasionally found in Oxfordshire. In August, I830, three apparently young birds alighted on some water on Otmoor, and were all killed by a farmer, who took them to the Messrs. Matthews immediately after (Zoologist, p. 2602). It is possible that these were hatched in the locality. On the 7 th November, I885, I saw upon Clattercote Reservoir a duck which could only have been of this species; it was swimming in company with nine Teal, than which it was slightly but pereeptibly larger at first glance, colder and greyer in colour, with more contrasted tints. Mr. Prior informs me that he has a specimen which was shot near Banbury, while a remarkably fine drake, preserved in that town, was procured in the Cherwell meadows about 1877 . The Messrs. Matthews stated that it had been sometimes, but rarely, killed in their neighbourhood in winter.

\section{THE WIGEON.}

Mareca penelope.

The Wigeon is a winter visitor, a few being procured every year, but it is only in exceptional seasons that it arrives in any numbers. On the Ist March, I879, in very mild weather following severe frosts in the winter, I saw great numbers of Wigeon, together with other forwl, in the meadows at the junction of the Sorbrook and Swere with the Cherwell, which had been in a flooded condition for some weeks. The Wigeon 
were in 'companies' of from a dozen up to fifty, and were a pleasing sight as they wheeled about in the sun, the air being' full of the sound of their soft whistling cry. The latest date in spring at which $\mathrm{I}$ have known the Wigeon to occur in Oxon is the 7th April, on which date, in I888, I saw a fine drake on the Isis near Eynsham. From his unwillingness to leave a particular part of the river, I think it possible that it was a paired bird, and that the duck may have been somewhere in the vicinity. Although, according to the editor of the last edition of 'Yarrell,' the Wigeon has never been proved to have bred in any part of England or Wales, it is believed to have done so in Norfolk and some other localities.

\section{THE POCHARD.}

Fuligula ferina.

The Pochard is a winter visitor, arriving about the end of October, often to be seen in some numbers on Clattercote Reservoir, where I have on several occasions observed from twenty to fifty on the water; on the 2nd January, I886, I counted no less than sixty-five there. To Mid-Oxon it is a frequent winter visitor, and I have known it killed upon the upper Isis. On the night of the 9th December, I88I, a fine drake Pochard was captured in a very curious manner, having dashed itself through the skylight of an outhouse in Banbury, where it was found quite uninjured. A faint light from a window near was shining on the skylight, which was frosted over, and I imagine the bird mistook it for a patch of water and pitched down on it.

\section{THE FERRUGINOUS DUCK.}

Fuligula nyroca.

The White-eyed, or Ferruginous, Duck is a rare visitor to this country in autumn and winter, and has occurred in three instances in Oxfordshire. Dr. Kirtland informed the 
Messrs. Matthews of a pair shot near Oxford in I 832 (Zoologist, p. 2539), and a second pair were procured in the same locality. in the winter of 1844 , of which Mr. W. Borrer furnished information to Mr. Yarrell (IIistory of British Birds, $4_{\text {th }}$ edition, iv. p. 4I9). On the 3 rd December, I 847 , another was shot on a fish pond at Cornwell, near Chipping Norton (G. Goatley). This specimen, Mr. W. W. Fowler tells me, is still preserved there.

\section{THE SCAUP DUCK.}

Fuligula mavila.

TuE Scaup is an occasional visitor, but being more attached to the flat muddy shores and estuaries on the coast, is not often found inland. The Messrs. Matthews, however, considered that, at the time they wrote, it was one of our commonest winter visitors, but, whatever may have been the case then, it is certainly of far from common oceurrence at the present day. The same authors mention that on the 24 th December, 1829 , a Scaup was caught in the basin in the quadrangle of Christ Church College, where it had settled in company with two others (Zoologist, p. 2539). Mr. A. H. Cocks has a drake in his possession which was shot on the Thames between Henley and Narlow, but outside the boundary of the county (in lit.). In the north of the county the scaup has occurred in a single instance on the canal near Banbury (W. Wyatt).

\section{THE TUFTED DUCK.}

\section{Fuligula cristata.}

The Tufted Duck is a regular, but not abundant, winter visitor to suitable localities. As might be expected from its extending breeding range, it has become more numerous with us of late years; there is indeed no reason to doubt that in the course of the next few years some individuals will even be found breeding within the confines of the county. Ten years ago a male shot on Clattercote Reservoir was considered a rare 
bird, but at the present time it is a regular visitor to that locality, arriving in October, and, if the water be unfrozen, remaining during the winter; parties of five or six may often be seen, and on the IIth December, I 886, I counted as many as a dozen in one bunch.

Here on the 28th March in the same year, a beautifully mild spring morning, following the protracted frost which lasted almost uninterruptedly from the first week in January, since which date the water had been ice-bound (bearing skaters on the I $3^{\text {th }}$ March), and all fowl had been banished, I saw a male and female Tufted Duck evidently paired, the male in most perfect plumage, with well-developed crest and snowy flanks. They swam quietly across the pool, the drake keeping a couple of feet in the rear, with a proud appearance of proprietorship, his almost constantly elevated head and neck, and vigilant attitude, making him appear even larger by contrast with his sombre mate, than was actually the case; the latter swam with her head drawn back resting on her shoulders, confiding her safety wholly to her protector. In their appearance and manners in fact they entirely agreed with the paired birds as I have seen them in their breedinghaunts in Nottinghamshire, and I confidently hoped that they might rear their young with us; but in this I was disappointed, for they disappeared shortly after.

To Mid-Oxon, and the Thames, the Tufted Duck is a regular winter visitor, and it is often shot on Port Meadow.

\section{THE GOLDEN-EYED DUCK.}

\section{Clangula giancion.}

The Golden Eye is a not uncommon winter visitor, females and immature males largely predominating, the adult drakes being rarely met with. On two occasions, however, in January, I 884, and December, 1886, I have observed drakes in fine plumage on Clattercote Reservoir; in each case they were 
accompanied by two birds in the browner dress of the female or young. The old male Golden Eye is a very conspicuous duck; on the second occasion here referred to, I first detected the presence of the drake as he headed a bunch of seven Tufted Ducks flying up the water, his superior size and pure white neck marking him out from the rest at the first glance. In the neighbourhood of Standlake, where the Golden Eye is of frequent occurrence, it is known to the gumners as the 'Curr' or 'Kerr' (Warner, MS.).

\section{THE LONG-TAILED DUCK.}

Havelda glacialis.

The Long-tailed Duck is a northern species, which only occasionally wanders as far as the southern shores of Great Britain in severe winters. Mr. Thomas Goatley informed the Messrs. Matthews that a young male was shot at Standlake in the winter of 1840 ; and they mention, on the authority of Dr. Kirtland, the occurrence of a second on the Isis, near Iffley, in January, I 846 (Zoologist, p. 2539).

\section{THE EIDER DUCK.}

Somateria mollissima.

THE Eider Duck as a straggler inland is extremely rare. The example recorded by Dr. Lamb as 'shot at Sunning, near Reading, in a severe winter,' was, no doubt, killed on the Thames, which here forms the county boundary (Omithologia Bercheria).

\section{THE COMMON SCOTER.}

\section{Edemia nigra.}

The Common, or Black, Scoter is an occasional visitor from the coast, of uncommon oceurrence. The Messrs. Matthews wrote of it as frequently visiting us in winter, but it can now only be considered as a casual visitor to Oxon. The oriy 
recent occurrence of which $I$ have had notice is that of a fine old male, procured in the flesh by Mr. W. Warde Fowler, which was stated to have been shot near Woodstock about the end of January, I888; it is now in Mr. A. H. Macpherson's collection. Dr. Lamb mentions a male and female shot on the Thames, near Reading, in October, I792 (Ornithologia Bercheria).

\section{THE VELVET SCOTER.}

Edemia fusca.

The Telvet Scoter is an occasional visitor of rare occurrence. The Messrs. Matthews state that they have seen specimens from the neighbourhood of Oxford during severe winters (Zoologist, p. 2539).

\section{THE GOOSANDER.}

Mergus merganser.

As a winter visitor the Goosander is of occasional, and irregular occurrence, several years often passing without its being noticed, while in some winters it has been observed on two or three oecasions during the season. The male, in its black and white adult plumage, has not, as far as I am aware, been procured in the county, unless the example shot on the Isis at Eynsham on the 5th January, I87I, and recorded as adult, was a male (A. II. Smee, Zoologist, I 87I); all the other specimens procured, or observed, being in the plumage of the female or young, in which stage there is an example (shot at Rousham in 1837 ) in the University Museum.

The following occurrences of the Goosander in recent years may be enumerated. A female at Islip, I 4 th November, I 88I (W. C. Darbey in lit.). An adult female at Standlake, 6th December, 1883 (W. H. Warner in lit.). One on the Isis near Oxford, December, I 884 (Darbey). An immature bird found dead near Hook Norton, January, , 887. A young male at Bicester on the $1 \mathrm{Ith}$ of the same month. One, shot from a party of three, on the Cherwell at Marston, 26th February, 
1887 (A. H. Macpherson in lit.). In the north of the county also an example was shot at Adderbury (W. Wyatt). The Messrs. Matthews write that it was often to be met with on our rivers during severe frost, but seldom visited us in milder weather (Zoologist, p. 2540).

\section{THE RED-BREASTED MERGANSER.}

Mergus serrator.

TuE Red-breasted Merganser is an occasional winter visitor, but of less frequent occurrence than the preceding species. The Messrs. Matthews record one shot on Otmoor in February, $\mathrm{I}_{3} 8$, and two near Cassington in the winter of 1841 (Zoologist, p. 2540), while the Rev. H. A. Macpherson has seen several immature birds which had been procured on the Isis in the neighbourhood of Oxford. Mr. G. Jackson, when living at Greenlands, near Henley, shot a female on the river there, on

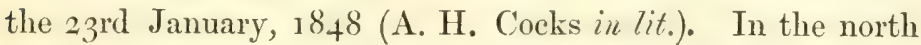
of the county a Red-breasted Merganser was shot in the neighbourhood of Wardington, on the Northamptonshire borders, in January, I\$77 (C. M. Prior, Zoologist, I877). The two birds procured at Cassington are a male and female, and are preserved in the Oxford Museum.

\section{THE SMEW.}

Mergus albellus.

Tre Smew is an occasional winter visitor. The Messrs. Mathews, writing of this species, say that 'although many females and young birds are annually killed in this county, yet the old males seldom appear except in the severest seasons. In January, 1838 , three adult males were killed at one shot on the Isis near Oxford ' (Zoologist, p. 2540). In the University Museum are examples of the adult male, and of the young, labelled 'Hampton Gay,' and 'Sandford,' respectively. Mr. W. Newton, jun., has one which was shot on the Thames at Benson (in lit.). 
Nowadays the visits of the Smew to Oxfordshire are of rare occurrence, a remark which unfortunately applies to many of the wading-and water-birds upon our list; the only specimen which has come under my notice of recent years is a female which was purchased by the Rev. B. D'O. Aplin, in December, I882, in Oxford market, where it had been sent up with other wildfowl from Otmoor. 

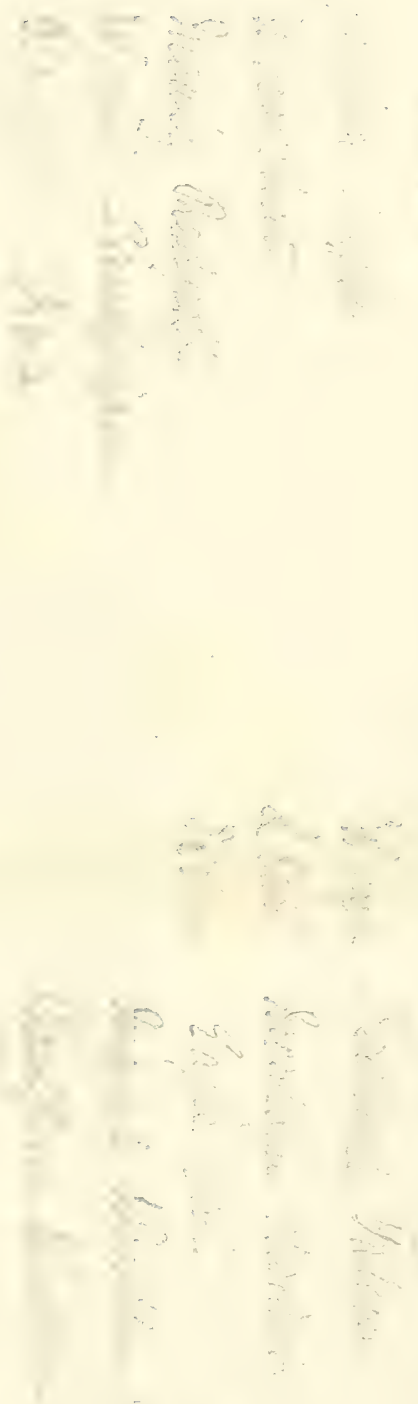



\section{ADDENDA.}

Tree Sparrow (p.86). I have recently examined an albino Tree Sparrow. The beak and legs are pinkish white, irides a rather dark pink. At first sight the whole plumage appears to be of a dirty white; but on closer examination, the chestnut of the crown, as well as the markings of the throat, cheeks, and upper parts, can be clearly traced in very faint shades of dull chestnut on a pure white ground. It was one of a brood of otherwise normal young taken from a hole in the wall of a cattle hovel in this parish, three years ago, and since then has lived in a cage in a cottage at Bodicote. Its owner was under the impression that it was a House Sparrow, but by its distinctive markings, as well as by its slender form, I was able to identify it as of the rarer species. Albino varieties of the Tree Sparrow are rare.

House Sparrow (p. 87). In some parishes it was formerly the custom for the Churchwardens to pay head-money for Sparrows, as well as for other vermin. The Bloxham Town Charges book for 1818 contains the following entry:'March Ioth. Paid Churehwardens for 90 dozen of Sparrows £I 2s. 6l.' A Sparrow Club, which existed in the parish forty years ago, has been revived in the present spring, and another was established in Mid-Oxon last year.

Crckoo (p. I I3). The Cuckoo seldom reaches North Oxon before the last week in April. In twelve years, I 878 to I889, 
the average date of my own observation of it has been the 27 th or 28 th. The earliest date is the 20 th, in 1833 .

The Wryneck (P. I2I). It is most unusual for the Wryneck to breed in any situation other than a hole in a tree. Early in June, I884, Mr. Bartlett, of Banbury, visited the colony of Sand Martins which have their burrows in the face of a sand-pit on Tadmarton IIeath. As he was about to put his hand into one of the holes, a small brown bird flew out very quickly and entered some bushes near at hand. At the end of the burrow seven pure white eggs were found in a slight nest of dry grass-probably an old nest of a Sand Martin. Although Mr. Bartlett watehed for a considerable time he was unable to olotain another sight of the bird. I saw some of the eggs a few days afterwards, and told the finder I thought they must be a Wryneck's. But as the situation was so unusual, I forwarded one of the eggs with an account of the incilent to the Editor of the Znotogiss, who appended to my communication the note, 'In shape and size the egg sent certainly resembles that of a Wryneck' (Zoologist, I 885 , p. 27). Mr. A. G. Butler, when writing of five fullfledged young of this species found by him in a hole in a brick-earth cutting (i). 1887, p. 299), remarked that he had 'never met with any recorded instance of the Wryneck breeding in a hole in the ground.'

Woodcock (p. I5I). Mr. Harcourt tells me that he considers the average number of Woodcocks annually killed in his Oxfordshire woods to be twelve. The mild winter of I 888-89 was a good season, and the number reached eighteen (in lit.). During the third week in January one of his keepers shot two Woodeocks, right and left, each of which weighed over a pound (Zoologist, I889, p. 149). This was a remarkable shot, for a Woodcock of twelve ounces is a good bird, and Yarrell says that fifteen ounces is far above the average. Mr. Harcourt adds, ' $I$ think the largest number I have ever reeeived in one day was eight Woodcocks, shot in 
Coggs' Coppice' (in lit.). In an interesting note on the nesting of the Woodcock, in the Zoologist (1880, p. 63), the Rev. A. Matthews writes_' While we were residing' in Oxfordshire, now twenty-five years ago . . . few years passed by in which a Woodcock's nest was not discovered in one or another of the great woods of Oxfordshire, and the adjacent counties.'

Turtue Dove (P. I 25). On the I I th May, I 889 , I counted thirteen Turtle Doves, males and fernales, in a field of young barley between Bloxham and Barford, the only occasion on which I ever met with any number of these birds together at that season. Doubtless they were new arrivals, and the sudden return of dull, cold weather may have had something to do with their flocking. They were feeding very eagerly, and when put up flew only a short distance before settling again. A pretty effect was produced by their broad, graduated, white-tipped tails when they all rose on the wing.

Redshaxk (p. 162). An example in full summer plumagre was shot on the Cherwell at Twyford Mill, a few miles below Banbury, on the $4^{\text {th }}$ May, I889.

Lesser Redpole (p. 94). Several pairs appear to be breeding in the parks at Oxford this year (1889).

Grey Wagtail (p. 76). A pair of these elegant birds have at the present time (Hay, I889) taken up their (quarters at the Mill on the Swere at Barford St. Michael, and evidently from their behaviour have a nest in some secure place in the stonework of the flood-gates. They are generally to be seen running about over the large stones in the rushing waters below the gates, or perched in the overhanging willows. The hand-rail of the wooden foot-bridge further down the stream is also a favourite resting-place.

Cirl Bunting (p. 83). Early in May, 1889, I saw a male of this species close to the village of Bloxham. My attention was first drawn to its presence by its sibilant song, which I had heard previously only in the South of England. 
The late Mr. Rodd gives a good description of the Cirl Bunting's song in the Birls of Commall (p. 53) - Its most usual song is like the trill of the Yellowhammer, but without the prolonged note at the end; when concealed in the foliage of trees its song is often more sibilous and rapid in delivery, and at a distance sounds not unlike that of the Wood Wren ( $P$. sibilatrix) but stronger in expression.'

Marsh Warbler (p. 6I). Mr. Fowler communicates the following note:-

' On May I $8, \mathbf{I} 888$, I noticed a Reed Warbler in a syringabush just outside the Botanic Gardens, singing with such extraordinary vigour and variety, that I stayed a long while listening to it. The bird, which was to all appearance an ordinary Reed Warbler, vanished in the course of the next day. This year (I889), on the 8th of May, it re-appeared in the same bush, and stayed some days. Its outpourings of song were astonishing, and were kipt up in spite of the noive of constant passers-by, and of a national school which is but a few yards from the bush. No Reed Warbler that I have ever heard could vie with it for a moment, and it even attracted the attention of the gardeners at work in the Botanic Gardens. I stole quictly under the bush and watched it twice for half-an-hour at a time. The flesh-colour of its legr, and the habit it had of perching on a twig, erect and vigorous, as well as the character of the song, suggested to me the possibility of its being the Marsh Warbler (Acrocephalus palustris); but it disappeared after four or five days, and it has not been possible to prove the fact. I hope to make aequaintance with the song of the Marsh Warbler on the continent this summer, and shall then be better able to judge.

W. W. F.'

[HaIRY Woodpecker (D). villosus). In the Zoologist for 1882, p. 69, I recorded the supposed occurrence of this American species between Hook Norton and Chipping Norton, about twelve years ago. It is very doubtful if the skin upon 
which the record was founded was that of the identical Woodpecker killed there.]

Hawfinch (p. 89). A pair of Hawfinches have reared their young in some market gardens in Neithrop, Banbury, this year (1889).

Crossbill (p. 97). Mr. Fowler has recently obtained satisfactory evidence of a pair of Crossbills lreeding at Iflley in 1888. 


\section{GLOSSARY OF LOCAL NAMES.}

Billy = Hedge Sparrow.

Blackcap = Coal and Marsh Titmouse.

Bottle-Tit = Long-tailed Titmouse.

Bumbarrel = Long-tailed Titmouse.

Buntlark = Corn Bunting.

Butcher-Bird $=$ Red-backed Shrike.

Chat $=$ Whinchat .

Corn Crake $=$ Landrail.

Cuckoo's mate $=$ Wryneck.

Curr $=$ Golden-eyed Duck.

Dabchick = Little Grebe.

Diver $=$ Great crested Grebe.

Double Snipe $=$ Great Snipe.

Dun Crow $=$ Hooded Crow.

Featherbed $=$ Willow Wren.

Felt $=$ Fieldfare.

Fiery Red-tail $=$ Redstart.

Firetail $=$ Redstart.

French Magpie = Long-tailed Titmouse.

Full Snipe $=$ Common Snipe.

Gizer $=$ Missel Thrush.

Gor Crow $=$ Carrion Crow.

Half Snipe $=$ Jack Snipe.

Haychat $=$ Whitethroat.

Hickle = Green Woodpecker.

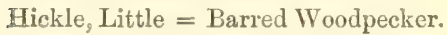

Hickle, Pied = Spotted Woodpecker. Horsematch $=$ Red-backed Shrike. Kerr $=$ Golden $\cdot$ eyed Duck.

Molly Hern $=$ Heron.

Mollyern $=$ Heron.

Muffler = Great-crested Grebe.

Norman Gizer = Missel Thrush.

Norman = Missel Thrush.

Nettlecreeper $=$ Whitethroat.

Owl, Marsh = Short-eared Owl.

Owl, Screech = Barn Owl.

Owl, white = Barn Owl.

Payfinch $=$ Chaffinch .

Piefinch $=$ Chaffinch

Pigeon-Felt $=$ Fieldfare .

Plover, Whistling = Golden Plover.

Reed Sparrow = Sedge Warbler.

Sea Swallow = 'Tern.

Spoonbill $=$ Shoveller Duck.

Summer Snipe = Common Sandpiper.

Thresher $=$ Song Thrush.

Titlark = Tree and Meadow Pipits.

Tomtit $=$ Blue Titmouse.

Trvit-me-dick = Quail.

Utick $=$ Whinchat.

Wagtail, Land = Ray's Wagtail.

Wagtail, Water $=$ Pied Wagtail.

Whistler $=$ Golden Plover. 


\section{IN DEX.}

A berdevine

Accentor, Hedge

Auk, Little

Avocet

Bittern, Common

Bittern, Little.

Blackbird

Blackcap.

Brambling

Bullfinch.

Bunting, Blackheaded

-, Cirl

-, Common

-, Corn

- Reed.

-, Snow .

-, Yellow

Bustard, Great

- Little

Buzzard, Common

—, Honey

-, Moor.

—, Rough-legged

Chaffinch

Chiffchaff

Chough, Alpin

Coot

Cormorant, Common

-, Green

Corn Crake

Crake, Corn

- , Little

-, Spotted

Crane, Common

Creeper, Tree.

Crossbill, Common, .

Crow, Carrion .

_, Gor

—, Grey .

- Hooded

-, Royston

Cuckoo

Curlew, Common

Curlew, Stone.

Dabchick

Daw
PAGE

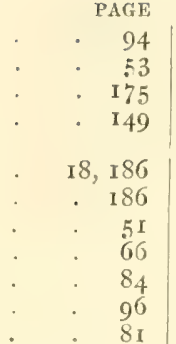

PAG

Dipper . . . . $4_{46}^{6}$

Diver, Black-throated . . I'7

-, Great Northern . . . $\quad$ I 76

一, Red-throated . . . I77

Dotterel . . . 6, I9, I.4

Dove, Ring . . . 19,122

一, Rnck. . . . $\mathrm{I} 24$

一, Stock . : . . 123

一, Turtle . . . I 25, 2 I I

Duck, Common Sheld- . . ing

-, Eider. . . . 205

-, Ferruginous . . 202

$6,83,211$ - Golden-eye . 204

$.2,82$-, Long-tailed . . 205

82 -, Pintail . . . . I99

SI -, Ruddy Sheld- . . . I06

8 I - Scaup . . . 203

82 -, Thifted . . . 203

I4I -, White-ejed . 202

$I_{42}^{2} \quad$ Wild . . . 7, I96

I8, 3I Dunlin . . . . . 155

33

34

32

Eagle, White-tailed

Eider, Commion

23

205

Falcon, Gyr . . . . $\quad 24$

-, Iceland . . . . . 23

- Peregrine. . . . 24

Fieldfare.

Finch, Bramble . . . $\quad 8 . t$

Flycatcher, Pied . . . 44

-, Spotted . . . . 44

Fulmar . . . . 173

Gadwall . . . . . In 8

Gannet . . . . 183

Garganey . . . . 221

Goatsucker . . . . 113

Godwit, Bar-tailed . . . . 163

—. Black-tailed . . . I 63

Golden-eye . . . 204

Goldfinch I9, 92

Goosander . . . 206

Goose, Bean . . . . Igo

—, Bernicle . . . . I0I

-, Brent . . . IgI

—, Canada . . . 192

—, Egyptian . . . . I9?

I 88 
Goose, Pink-footed

-, White-fronted

Grebe, Eared .

-, Great Crested

-, Little

-, Red-necked

-, Selavonian.

Greenfinch

Greenshank

Grouse, Black .

-, Sand .

Gull, Black-headed

-, Common

—, Great Black-backed

一, Herring

- Iceland

-, Kittiwake .

-, Lesser Black-backed

Guillemot, Common

Harrier, Ash-coloured

-, Hen

-, Marsh

—, Montagu's .

Hawfinch

Hawk, Sparrow

Hedge Sparrow

Hemipode, Andalusian

Heron, Common

-, Great White

-, Night

-, Purple

Hobby

Hoopoe

Ibis, Glossy

Jackdaw .

Jay .

Kestrel

Kingfisher

Kite

Knot

Lapwing .

Lark

Linnet

Magpie

Mallard

Martin, House

-, Sand .

Merganser, Red-breasted

Merlin

Moor-Hen

Nightingale

Nightjar

Nuthatch
PAGE

I00

I 89

181

7,177

7,181

180

180

92

162

127

I 25

168

169

I 71

170

172

I 72

I 71

175

- 35

I 8,34

34

19, 89,

9,213

5 ?

135

$4,7,8,153$

. 185

$1 \mathrm{~s} 5$

is 4

25

$\mathrm{II}_{4}$

$18 \mathrm{~S}$

I06

IOS

28

7,116

18,29

157

4,147

2, 3, 79

95

107

I96

I I O

4, 111

207

27

$7,8,139$

II, I9, 54

2 I, I I 3
Oriole, Golden .

PAGE

Osprey .

$\cdot 52$

-, Water

Owl, Barn

-, Brown

-, Eagle

-, Long-eared

-, Short-eared

- Tawny

Oyster-catcher .

Partridge, Common .

-, Red-legged

Pastor, Rose-coloured

Peewit

Petrel, Fork-tailed .

—, Storm

Phalarope, Grey

_., Red-necked

Pheasant.

Pie .

Pigeon, Wood ,

Pipit, Meadow

—, Richard's

- Tree

Plover, Golden

-, Green

-, Grey .

-, Kentish

-, Norfolk

-, Ringed

Pochard.

Puffin

Quail, Common

Rail, Land

-, Water

Raven

Razor-bill

Redbreast

Redpole, Lesser

Redshank, Common .

$\rightarrow$ Spotted

Redstart.

-, Black .

Redwing .

Reeve

Reedling .

Roller

Rook

Ruff

Sanderling

Sand Grouse

Sandpiper, Common .

—, Curlew

—, Green

-, Purple
19,38

35

38

36

37

35

149

- 128

19, 129

- 99

4,147

I74

- I7t

150

151

127

ro7

I 22

78

79

78

I 45

$4, \mathrm{I} 47$

147

145

142

I 45

202

I 76

19, 133

- 136

7,138

18, 102

175

53

94, 2 I I

I 62,2 I I

- I62

56

$5^{6}$

49

I 58

72

II 5

- 105

- 158

- 157

- 125

$7,8, I_{5} 8$

157
$7,8,160$

$7,8,160$
157 


\begin{tabular}{|c|c|c|c|c|c|c|c|}
\hline \multirow{2}{*}{\multicolumn{2}{|c|}{ Sandpiper, Wood }} & & $G E$ & & & & \\
\hline & & & . 161 & Tern, Sooty & - & - & \\
\hline aup & & & - 203 & Thicknee & & . & . \\
\hline \multicolumn{2}{|c|}{ Scoter, Common } & & - 205 & Thrush, Mistle & etoe & - & \\
\hline \multirow{2}{*}{\multicolumn{2}{|c|}{- Shag }} & & 206 & -, Song & & . & \\
\hline & & & I $S_{2}$ & Titmouse, Bea & arded & . & \\
\hline \multicolumn{2}{|c|}{ Shearwater, Manx } & & . $\quad 173$ & -, Blue . & · & - & . \\
\hline \multicolumn{2}{|c|}{ Sheld-duck } & & 196 & 一, Coal . & 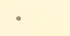 & . & - \\
\hline \multirow{2}{*}{\multicolumn{2}{|c|}{$\begin{array}{l}\text { Sheldrake } \\
\text { Sheldrake, Ruddy }\end{array}$}} & & . 196 & -, Great . & & . & - \\
\hline & & & . 196 & ong-taile & & & \\
\hline \multicolumn{2}{|c|}{$\begin{array}{l}\text { Shoveller. } \\
\text { Shrike, Great Grev }\end{array}$} & & . 199 & -, Marsh & - & - & . \\
\hline \multirow{2}{*}{\multicolumn{2}{|c|}{$\begin{array}{l}\text { Shrike, Great Grey } \\
-, \text { Pallas }\end{array}$}} & & 40 & Tree- & • & - & - \\
\hline & & & 40 & Turnst & - & & \\
\hline \multicolumn{2}{|l|}{-, Red-backed } & & $4^{2}$ & Twite & - & - & - \\
\hline \multicolumn{2}{|l|}{ Siskin Woodchat. } & & 43 & & & & \\
\hline \multirow{2}{*}{\multicolumn{2}{|c|}{ Skua, Arctic . }} & & - 94 & Wagtail, Grey & & - & $7^{6}$, \\
\hline & & & · 173 & - & - & - & \\
\hline \multicolumn{2}{|c|}{-, Pomatorhine } & & ; & 一, & $\cdot$ & - & - \\
\hline \multicolumn{2}{|c|}{$\begin{array}{l}\text {-, Richardson's } \\
\text { Skylark. }\end{array}$} & & I & - & • & - & - \\
\hline \multirow{2}{*}{\multicolumn{2}{|c|}{$\begin{array}{l}\text { Smew } \\
\text { Snipe, Common }\end{array}$}} & & $\begin{array}{r}79 \\
. \quad 207\end{array}$ & Warbler, Dart & tford & : & : \\
\hline & & & 18,153 & - & (1) & . & $\dot{0}$ \\
\hline \multicolumn{2}{|l|}{$\begin{array}{l}\text { Smpe, Common } \\
\text {-, Great. }\end{array}$} & & . $\quad 152$ & 一, & & . & \\
\hline & & . 154 & - & . & . & $6 \mathrm{I}, 2$ \\
\hline \multirow{2}{*}{\multicolumn{2}{|c|}{$\begin{array}{l}\text { Sparrow-Hawk } \\
\text { Sparrow, Hedge }\end{array}$}} & & 28 & $\rightarrow$ & . & . & $\cdot 4$ \\
\hline & & & 53 & - & . & - & \\
\hline \multicolumn{2}{|l|}{$\begin{array}{l}\text {-, House } \\
\text { - Tree }\end{array}$} & & $19,87,209$ & Wa & - & - & \\
\hline \multirow{2}{*}{\multicolumn{2}{|c|}{ Starling : : }} & & 86,209 & . & - & - & \\
\hline & & & I9, 98 & & - & . & \\
\hline -, Rose-colour & red & & 99 & & - & · & \\
\hline Stilt Plack-mi & inged & & - 149 & and & & - & \\
\hline & & & - 155 & oat, $\mathrm{C}$ & Gre & er & \\
\hline$\varepsilon^{\prime}$ & & & . 156 & -1 & - & . & \\
\hline & . & & 5 & & - & . & \\
\hline & - & & . $\quad 1+2$ & & - & . & \\
\hline & . & & . & re & - & . & \\
\hline & . & & . Is & & . & - & I5I, 21 \\
\hline & & & . $10 S$ & & 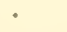 & - & \\
\hline ick' & & & - 194 & 1 & & - & $\cdot($ \\
\hline & $\cdot$ & & . & Wo & Gre & ottec & \\
\hline & . & & . 194 & - & - & - & \\
\hline & - & & - $I$ & - & & . & \\
\hline per &  & & . 1 & er Spot & tte & - & \\
\hline & $\cdot$ & & - III I & $\ldots$ & . & . & - \\
\hline ine & - & & . 112 & Vren & - & - & II \\
\hline & . & & $7,8,200$ & estec & & . & . \\
\hline & . & & .167 & $\rightarrow$ & ested & . & : \\
\hline & . & & 19,165 & - & . & . & \\
\hline on & . & & - 10 &,- 1 & . & . & - \\
\hline 1 & . & & - $\quad$ I & Wryneck. & - & - & I 21 , \\
\hline wich & : & & . 16 & Yellow-Hamm & & • & \\
\hline
\end{tabular}

THE END. 



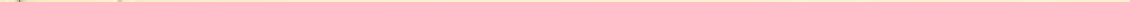





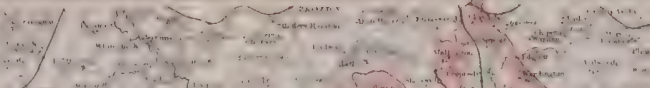

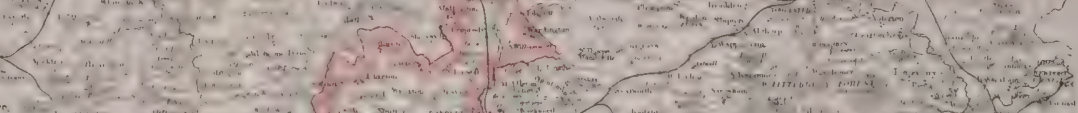

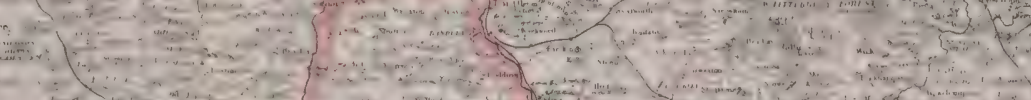
(1)



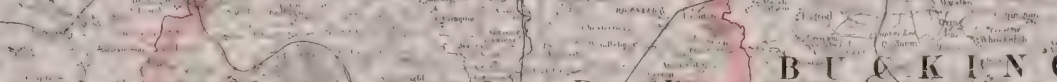
$0 \times \mathrm{N}-\mathrm{O}-\mathrm{R}=\mathrm{i}$



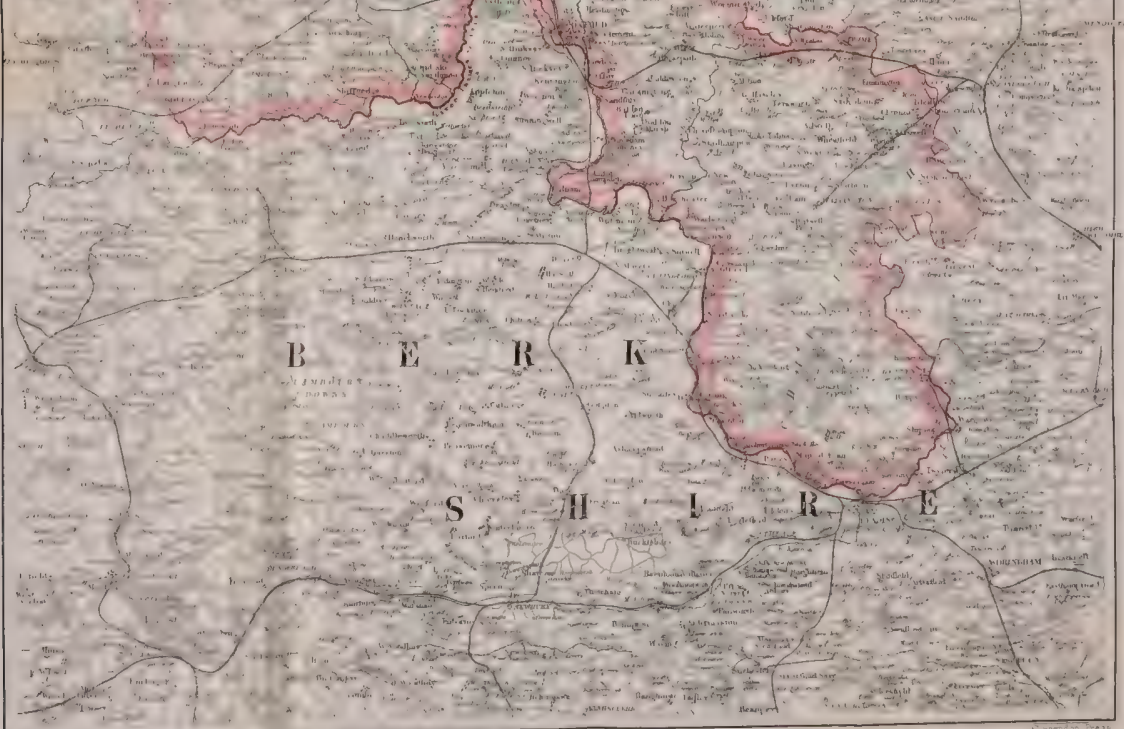



st

41126 
, 
SMITHSONIAN INSTITUTION LIBRARIES

||||||||||||||||||||||||||||||||||||||||||||||||||||||||||||||||||||||||||||||||||||||||

nhbird OL690.A45

The birds of Oxfordshire. 